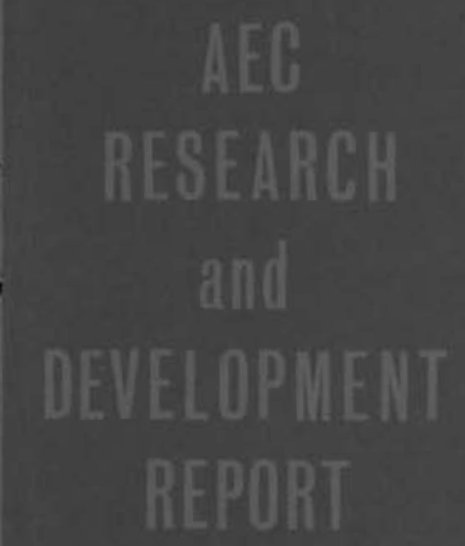

\section{NUCLEAR SAFETY QUARTERLY REPORT JANUARY, FEBRUARY, MARCH, 1967 \\ FOR

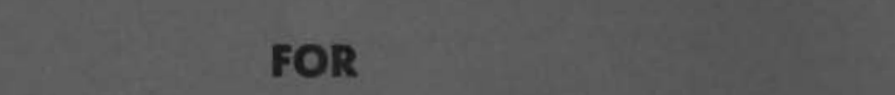

USAEC DIVISION OF REACTOR DEVELOPMENT AND TECHNOLOGY
NUCLEAR SAFETY BRANCH

OF

BNWL-433
F. W. ALBAUgh
J. J. FUQUAY
H. HARTY
E. E. VOILAND
D. C. WORLTON

JULY 1967

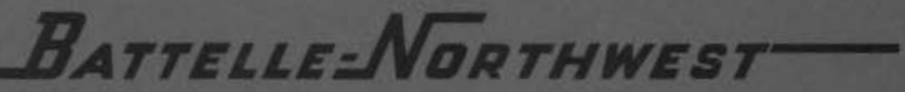

BATTELLE MEMORIAL INSTITUTE / PACIFIC NORTHWEST LABORATORY 
INFORMATION CONCERNING USE OF THIS REPORT

\title{
PATENT STITUS
}

This document copy, since it is transmitted in edvance of patent clearance, is made avoilable in confidence solely for use in performance of work under contracts with the U.S. Atomic Energy Commis. sion. This document is not to be published nor its contents otherwise disseminaled or used for purposes other than specified above before patent approval for such release or use has been secured, upon request, from the Chief. Chicago Patent Group, U. S. Atomic Energy Commission. 9800 So. Coss Ave., Argonne, Iitinois.

\section{PRELIMINARY REPORT}

This report contains information of a preliminary nature prepared in the course of work under Atomic Energy Commission Contract AT(45-1)-1830. This information is subjest to correction or modifica. tion upon the collection and evaluation of odditional data.

\section{LEGAL, NOTICE}

This report was prepared os an account of Government sponsored work. Neither the United States, nor the Commission, nor any person ecting on behalf of the Commission:

A. Makes any warronty or representation, expressed or implied, with respect to the accurocy, com: pleteness, or usefulness of the information contained in this report, or that the use of any information, apporatus, method, or process disclosed in this report may not infringe privotely owned cights or

B. Assumes any liabilities with respect to the use of, of for damages resulting from the use of ony information, apparafus, method, or process disclosed in this report.

As used in the above, "person acting on behalf of the Conmission" includes any employee or contractor of the Commission, or emplayee of such controctor, to the extent that such employee or con. tractor of the Commission, or employee of such contractor prepores, disteminates, or provides access to. ony information pursuant to his emplayment or contract with the Commission, or his employment with such coniractor.

\author{
PACIFIC NORTHWEST LABORATORY \\ RICHIAND, WASHINGTON \\ operated by \\ BATTELLE MEMORIAL INSTITUTE \\ for the \\ UNITED STATES ATOMIC ENERGY COMMISSION UNDER CONTRACT AT(45-1)-1830
}

PRINTED BY/FOR THE U.S. ATOMIC ENERGY COMMISSION 


\title{
- LASSIFIED \\ 33679000605719
}

\author{
BNWL -433
}

UC-41, Health and Safety

Special Distribution

NUCLEAR SAFETY QUARTERLY REPORT

JANUARY, FEBRUARY, MARCH, 1967

FOR

NUCLEAR SAFETY BRANCH

$O F$

USAEC DIVISION OF REACTOR DEVELOPMENT AND TECHNOLOGY

By

F. W. Albaugh

J. J. Fuquay

H. Harty

E. E. Voiland

D. C. Worlton

July 1967

PACIFIC NORTHWEST LABORATORY

RICHLAND, WASHINGTON 


\section{FOREWORD}

This report is the first of a quarterly series on nuclear safety. In these, Pacific Northwest Laboratory will report all of its nuclear safety related studies to the USAEC Division of Reactor Development and Technology. 


\section{TABLE OF CONTENTS}

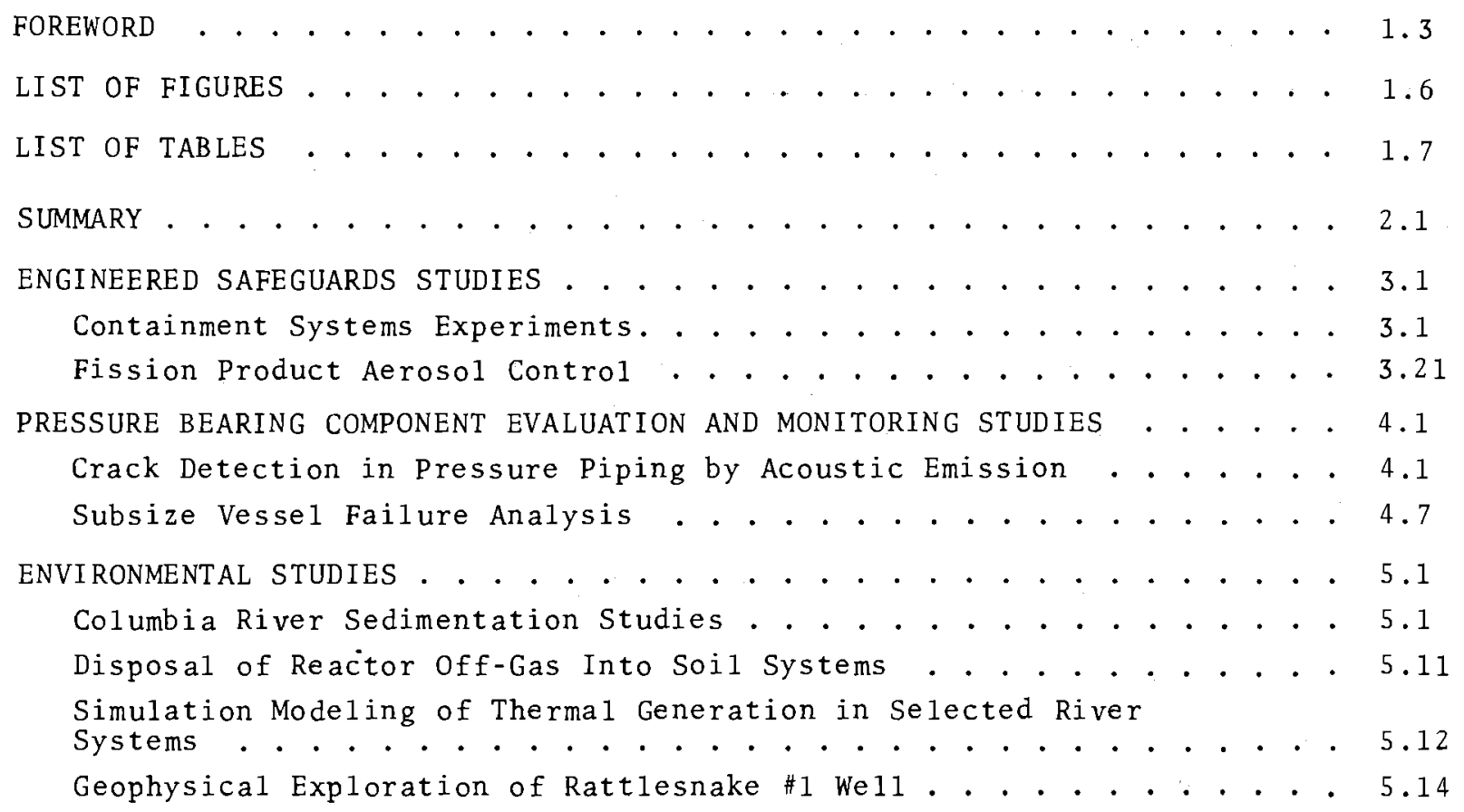




\section{LIST OF FIGURES}

3.1 Leakage Rate Compared Laminar Flow Equivalent

3.3

3.2 Comparison of Transport Mode1 with ADF Run 63

3.6

3.3 Comparison of CSE and ADF Maypack Samplers

3.15

3.4 CSE Reactor Vesse1 277T Building Layout

3.17

3.5 CSE Reactor Simulator Vessel with Sample Dummy Core Plate

3.6 CSE Reactor Simulator PWR

3.19

3.7 CSE Reactor Simulator BWR

3.20

4.1 Static Burst Test Arrangement for Study of Acoustic Emission

4.3

4.2 Compilation of Data from Static Burst Test of a 3 in. diam $x$ $1 / 4$ in. Wa11 x 36 in. Long, Type A-106-B Carbon Stee 1 Pressure Vessel

4.3 Spectrum Analysis Static Burst Test Data Type A-106-B Carbon Steel

4.4 Examples of Signal Source Location from Static Burst Test Data

4.5 Spectrum Analysis of Hydraulic Noise Data from an Operating Reactor and from a Hydraulic Test Loop

4.6 Drop Weight Specimen Behavior of A212B Near DWTT of $-30{ }^{\circ} \mathrm{F}$

4.7 Charpy and Drop Weight Test Results of A212B Stee1

5.1 Effect of Reactor Shutdown on Transport Rate of $65 \mathrm{Zn}$ at Three Points in the Columbia River

5.2 Effect of Reactor Shutdown on Transport Rates of $46 \mathrm{Sc}$ at Three Points in the Columbia River

5.3 Effect of Reactor Shutdown on Transport Rate of ${ }^{5}{ }^{1} \mathrm{Cr}$ at Three Points in the Columbia River

5.4 Effect of Reactor Shutdown on Transport Rate of $54 \mathrm{Mn}$ at Three Points in the Columbia River

5.5 Effect of Reactor Shutdown on Transport Rate of ${ }^{60}$ Co at Three Points in the Columbia River

4.4

4.5

4.6

4.8

4.9

4.9

5.2

5.3

5.3

5.4

5.4

5.6 Transport Rate of Radionuclides by the Columbia Ri ver at Pasco, Washington, Hood River, Oregon and Vancouver, Washington for the Period January 1964 Through January 1965

5.5

5.7 Periods of Uptake and Release of $65 \mathrm{zn}$ by the Bed of the Columbia River Between the Hanford Reactors and Vancouver, Washington

5.6

$5.8 \quad 65 \mathrm{Zn}$ Activity in McNary Cores

5.7

$5.9{ }^{46} \mathrm{Sc}$ Activity in McNary Cores

5.8

$5.10{ }^{51} \mathrm{Cr}$ Activity in McNary Cores

5.9

$5.11{ }^{54} \mathrm{Mn}$ Activity in McNary Cores

5.9

5.1260 Co Activity in McNary Cores

5.10

5.13 Dimensionless Flow Rate as a Function of Geometry

5.14 Definition Sketch for Underground Injection of Radioactive Gases 


\section{LIST OF TABLES}

3.I Leakage Rate Data

3.2

3.II CSE Leak Rate Measurement by Xenon Collection

3.4

3. I I I

Influences on Mass Transport Processes

3.8

3.IV

Iodine Containment Behavior--Simulated Versus Irradiated Sources

3.9

3.V Gas Mass Transfer Coefficients--Simulated Versus Irradiated Sources

3.10

3.11

3.VI Retention of Elemental Iodine on Silver Screens

3.12

3. VII

Retention of Elemental Iodine on Silver Membranes

3.12

3. VI I I

Retention of Elemental Iodine on Glassfiber Filters

3.22

3.IX Operating Conditions for HS-1

3.22

3.X Operating Conditions for HS-2

3.23

3. XI Summary of Results of Flow System

3.24

5.I Curies per Day of Five Radionuclides Found in the Columbia River Above the Hanford Reactors

5.1 
3

, 


\section{SUMMARY}

ENGINEERED SAFEGUARDS STUDIES

J. M. Batch

Containment Systems Experiment (CSE)

Tests of leakage from the CSE containment vessel were completed for

- ambient temperature air. It was found that summing the individual leakage rates which were measured at al1 known leak points compared satisfactorily with total leakage rates as determined by the absolute and reference methods.

A mathematical model was developed for the concentration of fission products after a rapid release into a containment vessel. The model agreed well with experimental results using elemental iodine in a laboratory size tank.

Behavior of fission product simulants used in CSE tests was compared with the behavior of an aerosol from trace-irradiated $\mathrm{UO}_{2}$ sources in $1 \mathrm{ab}$ oratory tests. Comparison of gas mass transport coefficient was good for the two aerosols.

The efficiency of silver surfaces in Maypack filters for retaining elemental iodine was investigated. It was found that a $5 \mu$ pore silver membrane was very efficient, even at high mass loadings and high flow rates.

Tests with Maypack filters showed that retention of an excessive amount of the CSE aerosol on the commercial check valve at the entrance could be prevented by using a Teflon ball in a 2 in. long nipple.
Long-term release of the CSE simulant in an air sweep over molten Zircaloy-clad $\mathrm{UO}_{2}$ was only partially successful. With increasing time, oxidation of the $\mathrm{UO}_{2}$ evidently resulted in a decreased electrical conductivity of the melt material and the high frequency generator could not keep the material molten.

Installation of the large CSE pressure vessel was completed and blowdown tests were started.

Fission Product Aerosol Control

The study of removal of organic iodides with hydrazine sprays was continued using a new 4 ft diameter by $10 \mathrm{ft}$ tall spray tank. The results of the first two runs were considered very satisfactory although further tests will be required to establish optimum parameters.

Reaction kinetics between hydrazine and methyl iodide were studied using a flow system. It was found that the flow technique should be valuable for predicting the behavior of solutions to be used in the spray chambers by comparisons with solutions which have already been tested in the spray chamber.

PRESSURE BEARING COMPONENT EVALUATION AND MONITORING STUDIES

R. G. Wheeler Crack Detection in Pressure Piping by Acoustic Emission

A double cantilever beam specimen of A-302-B carbon steel was tested in 
cooperation with the Metallurgy Department to study the brittle fracture characteristics and the attendant acoustic emission. Limited acoustic emission detected was in the form of $100-120 \mathrm{kHz}$ bursts of about $50 \mu \mathrm{sec}$ duration. The test temperature $\left(-140{ }^{\circ} \mathrm{C}\right)$ introduced detection problems which must be overcome before adequate data can be obtained from low temperature tests.

Static burst tests have been performed using 3 in. diam by $1 / 4$ in. wa11 A-106-B carbon steel pipe. These tests were performed as the initial phase of the acoustic emission field application problem study, and also to study basic signal characteristics. Acoustic emission in the form of burst type signals was evident early in the test and increased abruptly in density and amplitude as the initial flaw began to propagate in a ductile manner. Triangulation verified the flaw as the signal source.

Analysis of hydraulic noise data from an operating reactor showed essentially a11 of the frequency content to be below $10 \mathrm{kHz}$. This demonstrated that the higher frequency components of acoustic emission above

$10 \mathrm{kHz}$ must be utilized in a practical crack monitor system.

Fabrication of experimental, multilayer electrostatic transducers by vapor deposition has been contracted with Thermionics, Inc., Hayward, California, to expedite evaluation of this technique. Three units--one each of $\mathrm{WO}_{2}, \mathrm{ZrO}_{2}$, and $\mathrm{SiO}_{2}$ dielectric with tantalum electrodes--have been received and partially tested. $\mathrm{WO}_{2}$ has been determined to be unsuitable for this application. $\mathrm{ZrO}_{2}$ and $\mathrm{SiO}_{2}$ stil1 look promising; however, a problem of shorting between succes sive layers is being experienced.

Subsize Vessel Failure Analysis

Irradiation increased the apparent fracture toughness of four A-212-B steel miniature pressure vessel specimens. The specimens contained a oneinch long machined slot through $80 \%$ of the wall thickness. From these results it is assumed there is either a significant increase in fracture toughness with irradiation or the bluntness of the notch combined with the irradiation induced increase in yield strength produced a false indication of increased toughness.

The preirradiation drop weight transition temperature of the steel used to make the vesse $1 \mathrm{~s}$ is $-30^{\circ} \mathrm{F}$. Post irradiation transition temperature has not yet been determined.

A large stainless steel block was irradiated in the Sandia Experimental Reactor Facility to determine the gamma heating to expect if this facility is used to irradiate heavy section specimens.

\section{ENVIRONMENTAL STUDIES}

\section{R. F. Foster}

Columbia River Sedimentation Studies

Radiochemical analyses were completed on samples of Columbia River water and sediments obtained during the summer of 1966 when the reactors were shut down. The transport of ${ }^{65} \mathrm{Zn},{ }^{54} \mathrm{Mn},{ }^{60} \mathrm{Co}$, and ${ }^{46} \mathrm{Sc}$ dropped steeply in the few days following 
shutdown, but not nearly as rapidly as would be expected from the data on release of these nuclides to the river via the reactor effluent. The bed of the Columbia River appears to act as a buffer to take up (and thus deplete

- from the water) radionuclides during most of the year, but to release - some of its load of isotopes back to the water during periods of low addition or high river flow. Chromium-51 is not depleted, scoured, or leached from the sediments to nearly as large an extent, probably because of its trivalent form.

Disposal of Reactor Off-Gas Into Soil Systems

On the study of disposal of reactor off-gas into soil systems, major emphasis was placed on methods for analyzing the injection of gas into homogeneous media through a single well. Graphs were developed to express flow rate as a function of the geometry of the system. The curves indicate that an injection structure may be placed near the water table without much sacrifice of flow rate, but such placement greatly increases time of gas travel back to the ground surface.

Simulation Modeling of Thermal Generation in Selected River Systems

Application of the digital simulation system, originally developed to assess the thermal impact of the Hanford plant on the Columbia, to the Illinois River below the Dresden plant appears satisfactory. Use of the model with data supplied by other government agencies on river soundings and hydrology and weather indicate that Dresden \#1 has only nominal temperature effects $28 \mathrm{miles}$ downstream. However, predictions for Dresden \#2 and \#3, either singly or in combined operations with the existing plant, are that significant effects on the temperature of the Illinois River will resuit at least as far as 40 miles downstream from the power plant site.

Geophysical Exploration of Rattlesnake No. 1 Wel1

All preliminary work for the geophysical exploration of the deep stratigraphic test well on Rattlesnake Hills was completed, except for the letting of the contracts for well cleanout and conditioning and for logging. In addition to completion of arrangements for access to the well, specification of work, and contractor selection, existing information about the well was examined and some samples taken at the time of drilling (1957 - 1958) were obtained. 


\section{ENGINEERED SAFEGUARDS STUDIES}

J. M. Batch

CONTAINMENT SYSTEMS EXPERIMENTS (CSE)

J. M. Batch

Containment Leakage Studies

- Air Leakage Rate Tests

M. E. Witherspoon

The leakage rate tests with the CSE containment vesse1 were com'pleted for ambient temperature air. The first nominal leakage rate was $1.0 \% /$ day by weight at $62 \mathrm{psig}$, and then the pressure was reduced and leaks measured at 30 and 10 psig without disturbance of individual leaks. Similar $1 y, 0.5 \%$ and $0.1 \% /$ day leakage rates were set at approximate 1 y $60 \mathrm{psig}$, and tests at $45,30,15,10,5$, and 1 psig were made without further adjustment of the individual leakage points. At the end of the tests at the nominal $0.1 \%$ /day leakage rate, the vessel was repressurized to 30 psig for a repeat test. Analysis of the data is still in progress, but a few typical results are shown in Table 3.1 to illustrate leakage rate variation with pressure at the three

- leakage rate levels, and to permit comparisons of the results obtained by different methods.

Leakage rates in column labeled REFERENCE are calculated from the rate of differential pressure change between containment and reference vessels on the assumption that the reference tube accurately monitors the average containment air temperature.

Differential pressures are observed on an inclined manometer readable to $0.01 \mathrm{in}$. water. Leakage rates in the columns labeled ABSOLUTE are calculated from absolute pressures read on a fused quartz bourdon tube pressure gage sensitive to $0.001 \mathrm{psi}$. Containment temperature in the ABSOLUTE (RTD) column is the volume weighted average of 19 platinum resistance temperature detectors. In the ABSOLUTE (NICKEL) column, temperature is inferred from the resistance change of a $415 \mathrm{ft}$. length of nickel alloy wire distributed so as to sense average containment air temperature. Both these 1atter temperature sensing schemes are sensitive to less than $0.1{ }^{\circ} \mathrm{F}$. The INDIVIDUAL COLLECTED column is the sum of individual leaks as measured by calibrated air rotameters on each leak.

It will be noted that the leakage rate results become somewhat unstable both between methods and with each method at different pressures during the $0.1 \% /$ day nominal leakage level series. This is believed to be the results of temperature variation in containment and iliustrates the difficulty of achieving reproducible results during such tests under conditions 


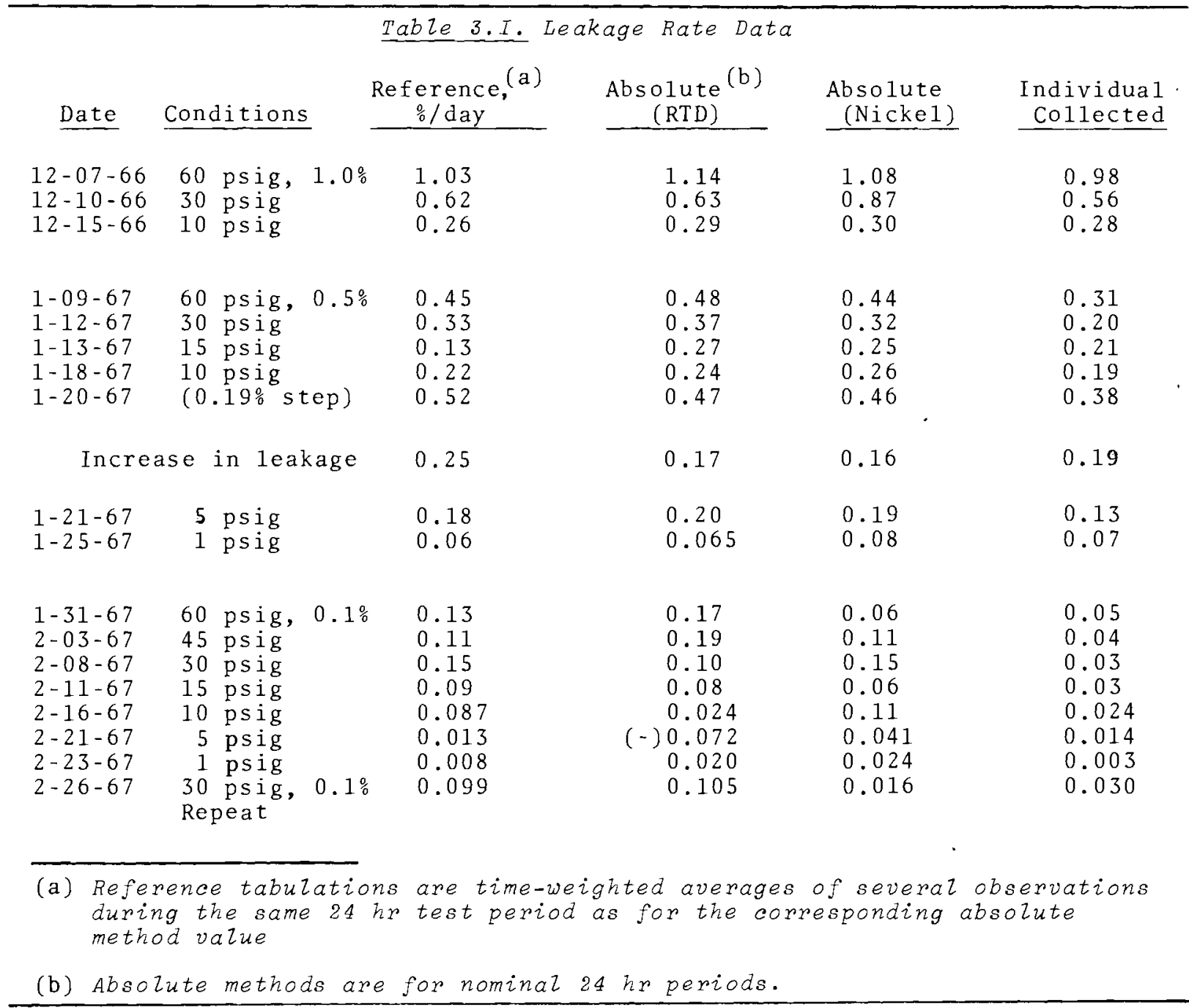

where temperature is not extremely stable during the test period.

Temperature of the air in the canyon outside the containment was monitored, and significant, rapid variations were observed. These data have not yet been analyzed to assess their effect on the leakage rate results.

From the work to date it is concluded that, in general, the summation of individual leaks accounts satisfactorily for the integrated leakage rate of the vessel and, thus, supports the measurements made by the integrated leakage rate techniques. Figure 3.1 shows the variation of leakage rate with pressure for nominal leakage rates of 1.0 and $0.1 \% /$ day and extrapolation formulas based on laminar flow regime. During the series at a nominal $0.1 \% /$ day leakage rate, the variation with pressure seems almost to be as predicted for orifice flow; however, it is suspected that data scatter is masking the true effect. 


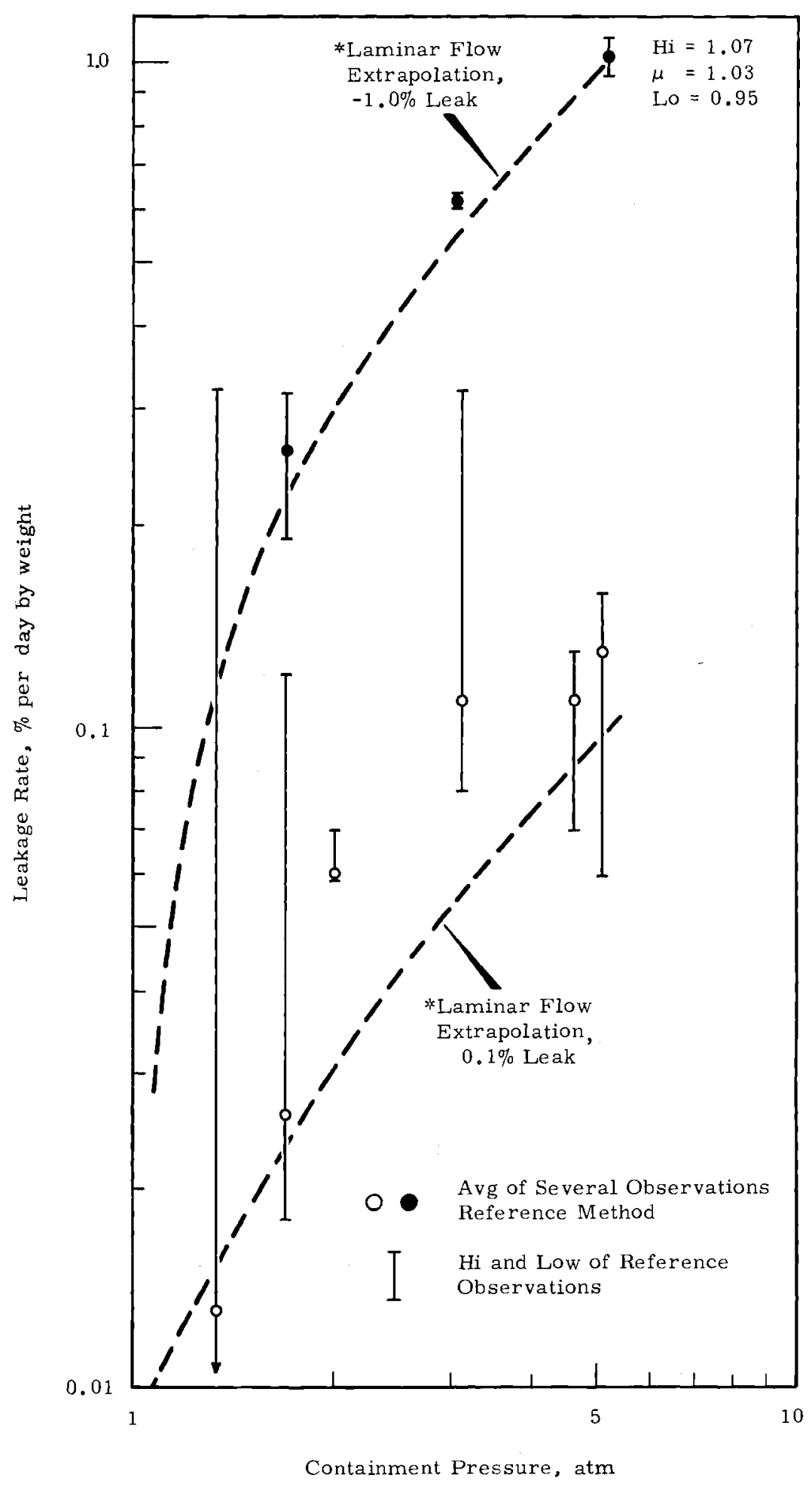

FIGURE 3.1. Leakage Rate Compared Laminar Flow Equivalent 
Xenon Tracer for Leak Rate

Measurement

J. D. McCormack and L. F. Coleman

One method of measuring leak rates from containment vessels is to inject a radioactive rare gas into the vessel and collect the leakage at individual leak points. This was done during a part of the air leak test series. One curie of ${ }^{133} \mathrm{Xe}$ was introduced into the vesse1. Samples were taken from five locations within the vesse1 until uniform xenon concentration was obtained. Five penetrations known to be leaking were monitored by collecting the escaping gas in refrigerated charcoal traps. Rotameters measuring air leak rate directly were also read for comparison.

Table 3.II shows that leak rate by xenon measurement averaged $10 \%$ higher than by rotameter reading; however, the variation for individual points is much higher. The results for penetration 39 Dov are noteworthy. This valve was on the end of a long pipe run from the 6 in. diam spray ring header; and the large variation between the two methods of measurement may reflect significant differences of xenon concentration in this large pipe reservoir and the main vessel.

The xenon collection tests provided a useful test of the injection and sampling equipment in advance of the large scale aerosol transport tests. Equipment performance was generally satisfactory. The worst trouble experienced was in regeneration of the charcoal traps; considerably longer heating and sweeping periods were required than was anticipated.

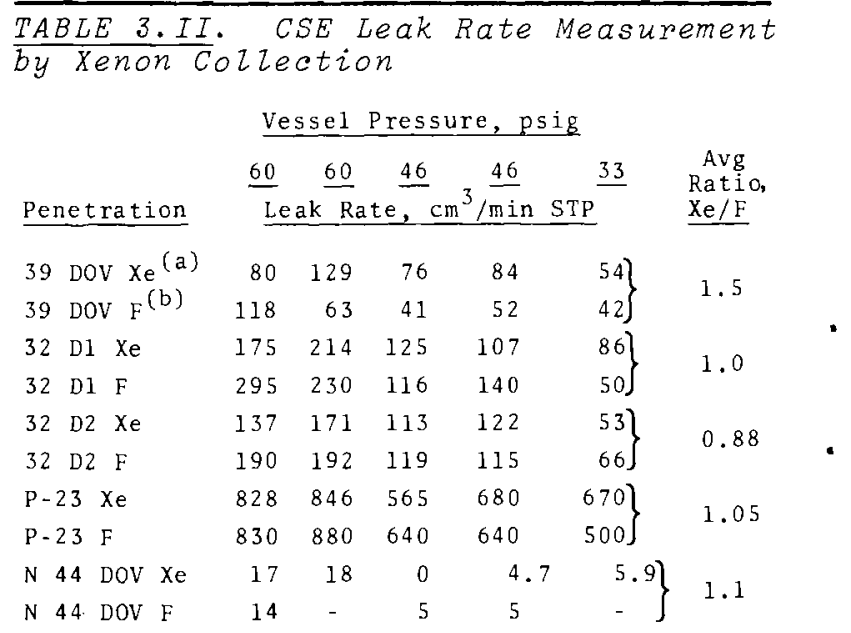

(a) Xe--by xenon collection

(b) $F-$-by flowmeter

Fission Product Transport Studies

Mass Transfer Mode1s

R. K. Hilliard

A mathematical analysis of the transport of fission products in a containment environment was made by means of overall material balances in the gas and liquid phases and on solid surfaces. A simplified case for the rapid release, constant pressure system used in most of the small scale containment experiments in the Aerosol Development Facility (ADF) is proving helpful in determining the important mechanisms involved during natural transport in a condensing steam system. The basic assumptions are listed be low.

1. At time zero the fission products are entirely in the vapor space at a uniform concentration.

2 . The vapor space is well mixed at al1 times. 
3. All interior surfaces are wet by steam condensation which forms a continuously renewed film flowing by gravity to the sump where it is continually withdrawn.

4. Fission products are absorbed reversibly from the gas by the liquid film.

5. Henry's Law holds for solubility in the liquid.

6. Fission products in the liquid film react irreversibly with the vesse1 walls with a first order reaction.

7. The concentration in the liquid film is uniform and related to the concentration in the sump by a inear proportionality constant.

8. The vessel is in thermal equilibrium at time zero and is maintained at equilibrium by constant addition of steam.

A11 assumptions except (3) and (7) are reasonably valid for the ADF conditions. Assumption (3) has the most serious effect on the model and its validity is being investigated.

The differential equations are (for any single species of fission product): Input = Output + Accumulation

$$
\text { Gas: } \quad 0=K_{G} A\left(C_{G}-C_{G}^{\prime}\right)+V \frac{d C}{d t} G
$$

Liquid: $\quad K_{G} A\left(C_{G}^{\prime}\right)=C_{L} S+R_{L} A_{L}^{\prime}$

$$
+L \frac{d C^{\prime}}{d t} L^{\prime}
$$

The definition of Henry's Law constant is

$$
\mathrm{C}_{\mathrm{G}}^{\prime}=\mathrm{HC}_{\mathrm{L}}^{\prime}
$$

Also, the relation between wall film concentration, $\mathrm{C}_{\mathrm{L}}^{\prime}=\mathrm{BC}_{\mathrm{L}}$

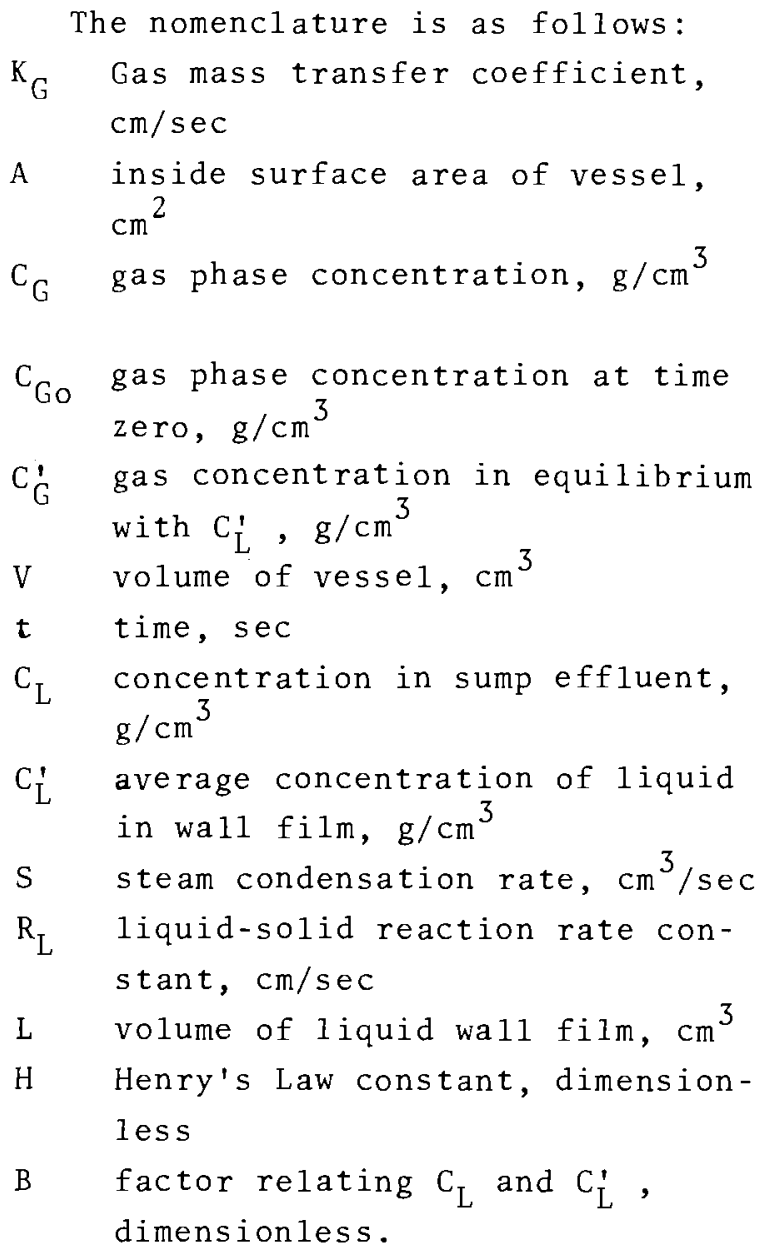

These equations were solved with appropriate boundary conditions and a program was written for the PDP-7 computer located at the CSE site. Input information required includes mass released, vesse1 volume, vesse1 surface area, liquid holdup volume, steam condensate rate, gas phase mass transfer coefficient, liquid-solid reaction rate constant, Henry's Law constant, and the proportionality factor relating concentration in the wall film to the sump concentration. Outputs are the roots of the equations and tabulated values of dimensionless concentration versus time. 
Figure 3.2 shows several curves obtained from this program using various combinations of the input variables. Also shown are experimental points from ADF Run 63 Maypack silver screens, which should be a measure of elemental iodine only. For the sake of clarity, only the curves close to the experimental points are shown.

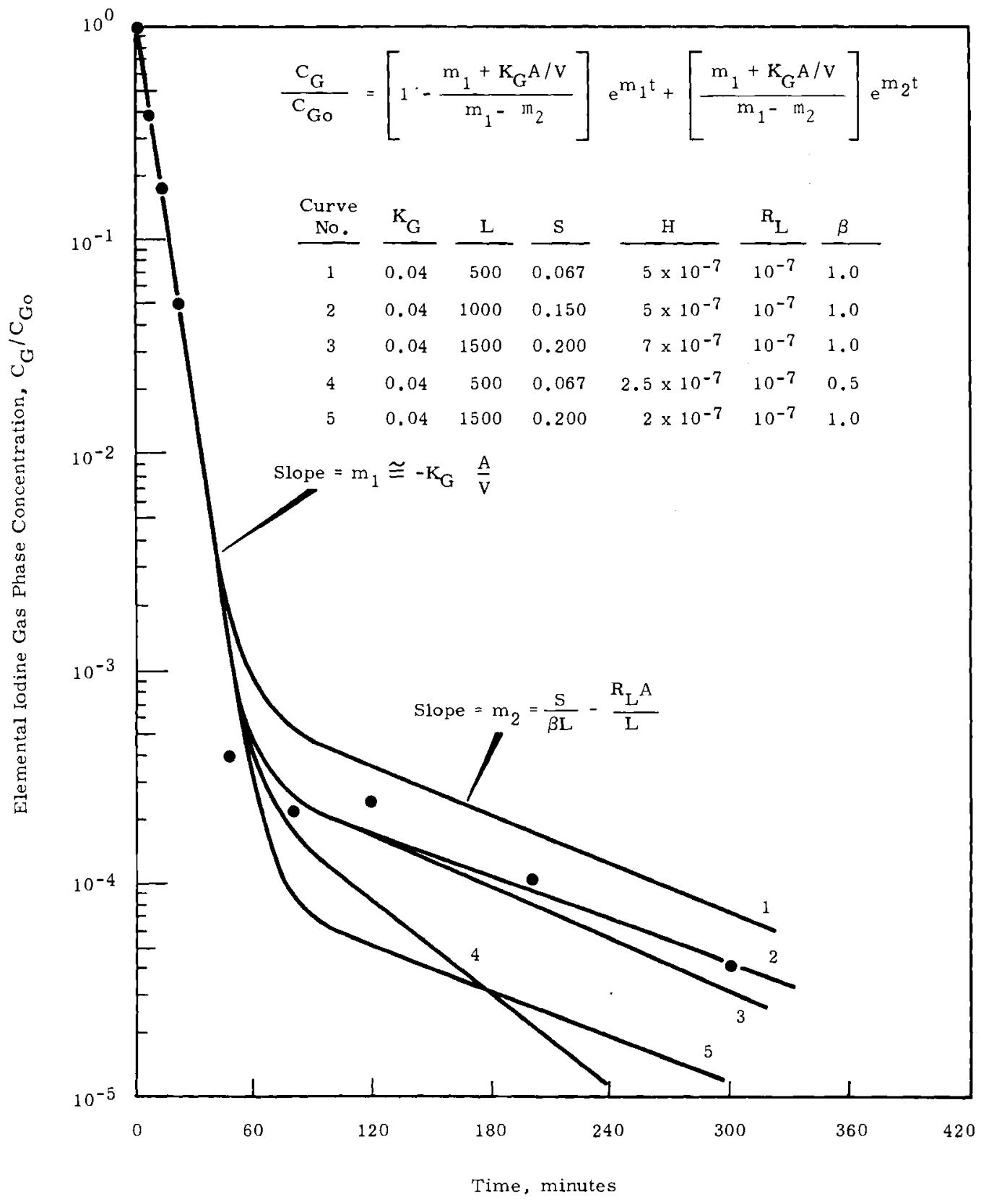


Several useful facts are displayed by this figure. The curve of $\log$ concentration versus time consists of two branches. At early times, the slope is approximately equal to $-\mathrm{K}_{\mathrm{G}} \mathrm{A} / \mathrm{V}$; that is, for a given vessel the transport from gas to liquid is directly proportional to the gas mass transport coefficient. All the other variables are unimportant except as they may affect the value of $\mathrm{K}_{\mathrm{G}}$ (e.g., $\mathrm{K}_{\mathrm{G}}$ is known to be influenced by the steam condensation rate).

The slope of the curve's first branch held constant until the dimensionless concentration decreased to $<10^{-3}$. The intercept of the curve and time zero depends chiefly on two of the variables, Henry's Law constant and liquid holdup volume. For this particular test, Henry's Law constant was calculated from Figure 3.2 to be approximately $1 \times 10^{-4} \mathrm{~atm} / \mathrm{mole}$ fraction, or a partition coefficient of $1 \times 10^{-7} \mathrm{~g} / \mathrm{cm}^{3}$ gas per $\mathrm{g} / \mathrm{cm}^{3}$ liquid. This is considerably lower than values reported in the literature. Two possible explanations are: (1) diffusion in the 1 iquid film may be important, with surface concentration much higher than average concentration, and (2) the vessel surfaces may be only partially wet by the film with some deposition on dry surfaces.

The slope of the second branch is essentially equal to $-\mathrm{S} / \mathrm{L}$; that is, the - rate at which the liquid film is diluted by fresh condensate. These two variables were experimentally measured as $0.22 \mathrm{~cm}^{3}$ condensate per second and $500 \mathrm{~cm}^{3}$ liquid holdup. Thus the experimental value for the ratio S/L is $4.4 \times 10^{-4} \mathrm{sec}^{-1}$; but the slope of the curve is $1.35 \times 10^{-4}$ $\mathrm{sec}^{-1}$. This suggests that some of the steam feed was condensing before it mixed with the iodine. This is possible, since the steam was fed directly through a wall nozzle.

The model is being expanded to include a continuous fission product source term and transport to partially wet surfaces. Values of liquid holdup volume as a function of condensation rate are being experimentally determined. Numerical methods are being attempted for application to unsteady pressure cases.

Fission Product Simulant Verification

R. K. Hilliard, J. D. McCormack and

L. F. Coleman

The factors which influence mass transport processes can be divided into two categories: (1) the properties of the material being transported and (2) the environment within which transport takes place. Both must be "simulated" in fission product transport experiments. The material is simulated by generating aerosols to represent the fission products and inert material released by thermal destruction of irradiated fuel elements. The environment is simulated by attempting to duplicate conditions of major importance which might prevail during an accident. Each category is important and must be considered for an understanding of the transport phenomena involved.

"Fission product simulant verification" may be considered to be the establishment of evidence that the physical and chemical properties of the simulant material are essentially identical to those of fission products which might be released in event of an accident. Verification may also be considered to be the similarity of trans port behavior of fission products and simulants under the same environmental conditions. The latter approach has been emphasized for the CSE simulant. 
The simple transport model discussed in the previous paragraphs can serve as an illustration. In Table 3.III the model input variables are listed in the first column while the second and third columns list some of the ways that material properties and environmental conditions affect each variable. The listing is by no means complete, but it shows the complexity of the environmental effects. Under some conditions, reasonable changes in the material properties are insignificant compared to reasonable changes in the environment. Simulant verification should be considered with these thoughts in mind.

More than fifty containment tests have been conducted in the Aerosol Development Facility, using both the $1.5 \mathrm{~m}^{3}$ painted aerosol tank (PAT) and the $0.9 \mathrm{~m}^{3}$ stainless steel aerosol tank (SAT). Traceirradiated stainless steel clad $\mathrm{UO}_{2}$

TABLE 3. III. Influences on Mass Transport Processes

\begin{tabular}{|c|c|c|}
\hline $\begin{array}{c}\text { Model } \\
\text { Input Term }\end{array}$ & $\begin{array}{l}\text { Material } \\
\text { Influence }\end{array}$ & Environmental Influence \\
\hline $\begin{array}{c}\text { Gas Mass Transport } \\
\text { Coeff., } \mathrm{K}_{\mathrm{G}}\end{array}$ & $\begin{array}{l}\text { Molecular weight } \\
\text { Particle size } \\
\text { Particle density } \\
\text { Electrical charge }\end{array}$ & $\begin{array}{l}\text { Atmos. composition } \\
\text { Atmos. condensation } \\
\text { Convection currents } \\
\text { Turbulence } \\
\text { Temperature } \\
\text { Pressure } \\
\text { Vessel geometry } \\
\text { Temperature gradients } \\
\text { Gravity or other forces } \\
\text { Electrical charges }\end{array}$ \\
\hline $\begin{array}{l}\text { Liquid-Solid Reaction } \\
\text { Rate Constant, }{ }^{R_{L}}\end{array}$ & Chemical activity & $\begin{array}{l}\text { Liquid properties } \\
\text { Solid properties } \\
\text { Temperature }\end{array}$ \\
\hline $\begin{array}{l}\text { Henry's Law } \\
\text { Constant, } H\end{array}$ & $\begin{array}{l}\text { Chemical activity } \\
\text { Vapor pressure } \\
\text { Solubility }\end{array}$ & $\begin{array}{l}\text { Liquid properties } \\
\text { Temperature }\end{array}$ \\
\hline $\begin{array}{c}\text { Vesse } 1 \text { Surface } \\
\text { Area, } A\end{array}$ & -- & $\begin{array}{l}\text { Vessel size } \\
\text { Wettability }\end{array}$ \\
\hline Vesse1 Volume, V & -- & $\begin{array}{l}\text { Vessel size } \\
\text { Compartmentation }\end{array}$ \\
\hline $\begin{array}{l}\text { Steam Condensation } \\
\text { Rate, S }\end{array}$ & -- & $\begin{array}{l}\text { Heat transfer rate } \\
\text { Temp. gradients } \\
\text { Mt1s. of construction } \\
\text { Convection currents } \\
\text { External conditions } \\
\text { Atmos. composition } \\
\text { Surface wettability }\end{array}$ \\
\hline $\begin{array}{l}\text { Liquid Holdup } \\
\text { on Wa11s }\end{array}$ & - & $\begin{array}{l}\text { Vessel size } \\
\text { Surface geometry } \\
\text { Surface wettability } \\
\text { Condensation rate }\end{array}$ \\
\hline
\end{tabular}


sources weighing $80 \mathrm{~g}$ were used in seven tests; various types and combinations of simulant materials were used in the remainder. Not all tests were performed under sufficiently similar environmental conditions to permit a direct comparison of the two types of aerosols, but some were fairly close. These have been averaged in Tables $3 . \mathrm{IV}$ and $3 . \mathrm{V}$.

The gas phase mass transport coefficient is one of the most important characteristics to compare. It was obtained from the slopes of the logarithm of gas phase concentration versus time curves as shown in Figure 3.2. The runs are grouped into two test series, within which direct comparison can be made between irradiated and simulant sources. Series A used uninsulated vesse1s with attendant high steam condensation rates. Series $B$ used insulated vesse1s. Mass transfer coefficients were relatively independent of source type and even of fission product element type. This was probably due to the fact that the test conditions were in the domain of environmental control.

However, the test conditions did vary considerably. Simulant concentrations ranged from 1 to $10^{5} \mathrm{\mu g} / \mathrm{m}^{3}$. Complexity of simulant mixture varied from one to six components. Although all the irradiated tests were performed in the painted vessel, the simulant tests used both painted and stainless steel tanks. The irradiated sources were heated in both oxidizing and reducing furnace atmospheres. One important variable probably affecting the results shown in Table $3 . \mathrm{V}$ is that a mechanical agitator fan was operated in containment in some of the simulant tests but in none of the irradiated tests. Agitation is known to increase the mass transport coefficient. The most significant effect on $\mathrm{K}_{\mathrm{G}}$ was the steam condensation rate, as shown by comparing Series A with Series B tests.

TABLE 3.IV. Iodine Containment Behavior--Simulated Versus Irradiated Sources

\begin{tabular}{|c|c|c|c|c|c|c|c|c|}
\hline \multirow{3}{*}{$\begin{array}{c}\text { Test } \\
\text { Series } \\
\end{array}$} & \multirow{3}{*}{$\begin{array}{l}\text { Aerosol } \\
\text { Source } \\
\end{array}$} & \multirow{3}{*}{$\begin{array}{c}\text { Average Steam } \\
\text { Cond. Rate, } \\
\text { g/sec/m } \\
\end{array}$} & \multicolumn{2}{|c|}{ Avg $K_{G}, \mathrm{~cm} / \mathrm{sec}$ (and } & Std. Dev.) & \multicolumn{3}{|c|}{$\begin{array}{c}\text { Avg Distribution } \\
\text { of Aerosol }\end{array}$} \\
\hline & & & Total & Particulate & Elementa 1 & at $5 \mathrm{hr}$ & Cont & inment, \% \\
\hline & & & Iodine & Iodine (a) & Iodine (b) & $\underline{\operatorname{Gas}}(\mathrm{c})$ & Sump & Walls \\
\hline \multirow{2}{*}{ A } & $\begin{array}{l}\text { Irradiated } \\
4 \text { tests }\end{array}$ & 0.40 & $\begin{array}{c}0.040 \\
(0.012)\end{array}$ & $\begin{array}{c}0.034 \\
(0.013)\end{array}$ & $\begin{array}{c}0.036 \\
(0.013)\end{array}$ & 0.50 & 70 & 30 \\
\hline & $\begin{array}{l}\text { Simulant } \\
5 \text { tests }\end{array}$ & 0.35 & $\begin{array}{c}0.052 \\
(0.010)\end{array}$ & $\begin{array}{l}0.051 \\
(0.004)\end{array}$ & $\begin{array}{l}0.050 \\
(0.019)\end{array}$ & 0.23 & 90 & 10 \\
\hline \multirow{2}{*}{ B } & $\begin{array}{l}\text { Irradiated } \\
2 \text { tests }\end{array}$ & 0.047 & $\begin{array}{c}0.015 \\
(0.002)\end{array}$ & $\begin{array}{l}0.014 \\
(0.0005)\end{array}$ & $\begin{array}{c}0.018 \\
(0.005)\end{array}$ & 1.1 & 56 & 43 \\
\hline & $\begin{array}{r}\text { Simulant } \\
6 \text { tests }\end{array}$ & 0.045 & $\begin{array}{l}0.016 \\
(0.010)\end{array}$ & $\begin{array}{c}0.016 \\
(0.008)\end{array}$ & $\begin{array}{l}0.019 \\
(0.013)\end{array}$ & 0.2 & 75 & 25 \\
\hline
\end{tabular}
(a) By analysis of Maypack filters
(b) By analysis of Maypack silver surfaces
(c) $>90 \%$ organic forms 


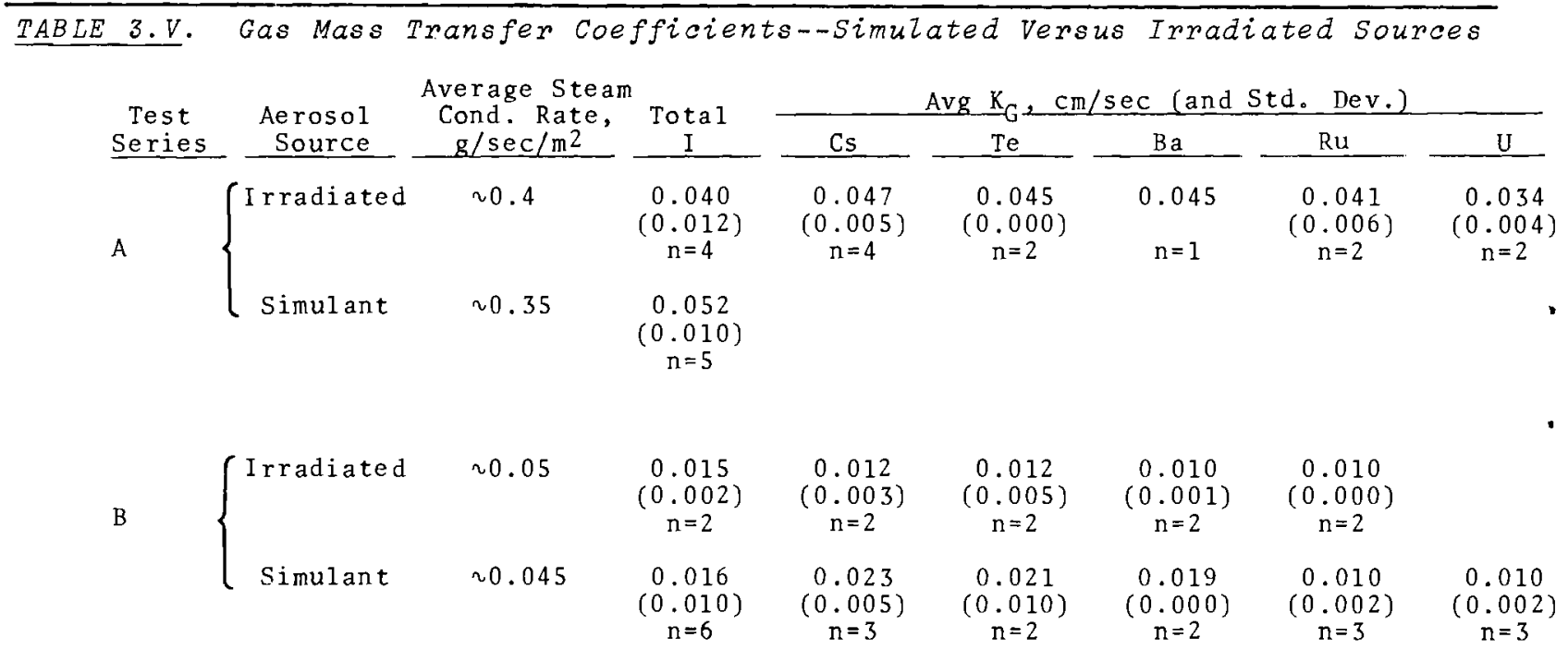

Although the comparison is considered to be good, the range of test conditions should be expanded and the effect of burnup should be investigated.

Maypack Behavior

J. D. McCormack

Gas phase aerosol concentration is perhaps the most important measurement in containment fission product transport experiments. Not only must the total mass concentration be determined as a function of time and space, but the measurement must be made in a manner such that the chemical and physical form can be inferred. Experimental evidence has shown that all of the important fission product elements except halogens and rare gases exist as particles in containment atmospheres, and can be sampled efficiently with filter papers. Refrigerated charcoal is usually used for sampling rare gases. Halogens, however, exist (perhaps in constantly changing proportions) as elemental vapor $\left(\mathrm{I}_{2}\right)$, volatile in- organic compounds (hydrogen iodide), nonvolatile compounds (iodates, iodides), volatile organic compounds (alkyl iodides), and any of the preceding adsorbed on, or occluded in, foreign particles. No single, simple sampling device is known which can unequivocally discriminate between a11 these possible iodine forms.

One device used with partial success is the so-called Maypack, named after Fred May, Harwe11, England. May's original device was simply a series of filters and adsorbers held within a compact body of convenient size. Many modifications have been made of the types and sequential arrangement of the components, but the principle remains the same: remove only one iodine form on each Maypack component. Unfortunate1y, clear discrimination is not always obtained and some smearing usually takes place. Proper design and control of sampling conditions are required for satisfactory separation. 
The efficiency of various Maypack components for discriminating between particulate associated iodine, elemental iodine, hydrogen iodide, and methyl iodide has been studied in the $A D F$ and results published in previous - quarterly reports.

Recently, the efficiency of silver surfaces for retaining elemental

iodine was investigated. The iodine was released by evaporation of an $\mathrm{I}_{2}-\mathrm{CCl}_{4}$ solution over a $5 \mathrm{~min}$ period. The CSE-type Maypacks were loaded with either 0.5 or $5.0 \mathrm{mg}$ of iodine at flow rates from 0.013 to $2.0 \mathrm{ft}^{3} / \mathrm{min}$. A flow rate of $1.0 \mathrm{ft}^{3} / \mathrm{min}$ corresponds to a superficial velocity of $60 \mathrm{ft} / \mathrm{min}$. Air of about $40 \%$ relative humidity and room temperature was the carrier. Efficiency in steam-air mixtures was shown by earlier tests to be satisfactory ( $>98 \%$ retention on six silver screens), but the room air tests gave generally poorer efficiency.
Table 3.VI shows the decreasing efficiency with increased flow rate for Maypacks using six silver screens. It also shows that higher mass loading results in lower efficiency. Loadings in the large scale CSE tests are expected to range from $5 \mathrm{mg}$ down to $0.1 \mathrm{\mu g}$.

The efficiency of $5 \mu$ pore silver membranes manufactured by Selas Flotronics, Springhouse, Pennsylvania, was found to be good for even the highest mass loadings and flow rates, as shown by Table 3.VII. The decision was made to use six screens followed by one silver membrane in the CSE tests. Efficiencies for retaining elemental iodine will be $>99 \%$ for any sampling condition envisioned.

Retention of elemental iodine on glassfiber filters is shown in Table 3.VIII. The normal sequence of Maypack components is: (a) two filters for removing particles, (b) silver

TABLE 3.VI. Retention of Elemental Iodine on Silver sereens (Air carrier, $25{ }^{\circ} \mathrm{C}, 40 \%$ Relative Humidity)

\begin{tabular}{|c|c|c|c|c|c|}
\hline \multirow{2}{*}{$\begin{array}{l}\text { Mass } \\
\text { Loading, } \\
\mathrm{mg}\end{array}$} & \multirow{2}{*}{$\begin{array}{r}\text { Flow } \\
\text { Rate, } \\
\mathrm{ft} 3 / \mathrm{min} \\
\end{array}$} & \multicolumn{4}{|c|}{ Percent Retained } \\
\hline & & Filters (a) & $\begin{array}{l}\text { Six Silver } \\
\text { Screens (b) }\end{array}$ & $\begin{array}{l}\text { Charcoal } \\
\text { Paper(c) }\end{array}$ & $\begin{array}{l}\text { Charcoal } \\
\text { Bed (d) }\end{array}$ \\
\hline 0.5 & 0.013 & 1.2 & 98.0 & 0.8 & 0.02 \\
\hline 0.5 & 0.2 & 1.9 & 96.3 & 1.8 & 0.04 \\
\hline 0.5 & 0.5 & 1.2 & 91.7 & 7.1 & 0.04 \\
\hline 0.5 & 1.0 & 1.1 & 78.8 & 19.7 & 0.2 \\
\hline 0.5 & 1.5 & 1.1 & 70.1 & 28.6 & 0.3 \\
\hline 5.0 & 0.013 & 0.4 & 99.0 & 0.6 & 0.01 \\
\hline 5.0 & 0.2 & 0.5 & 79.7 & 20 & 0.05 \\
\hline 5.0 & 1.0 & 0.5 & 64 & 35 & 0.2 \\
\hline 5.0 & 1.5 & 0.4 & 53 & 46 & 0.7 \\
\hline
\end{tabular}

(a) Two Gezman type A glassfiber

(b) 100 mesh copper, electroplated with $0.012 \mathrm{~mm}$ sizver

(c) Ge Zman type $A C$

(d) $80 \mathrm{~g}$, unimpregnated coconut, 8-14 mesh 
surfaces for removing elemental iodine, (c) charcoal impregnated paper for removing traces of elemental iodine penetrating the silver and high molecular weight organic iodides, and finally (d) about two inches of charcoal granules to remove methyl iodide. Thus it is intended that the filters retain a minimum of vapor form iodine. Unfortunately, some elemental iodine is adsorbed on the glassfiber filter media, with the highest fraction occurring at the lowest mass loadings. Pretreating the filter with Dri-film (trade name for dimethyldichlorosilane) or chlorine reduced the adsorption, as shown in the table. Dri-filmes-. pecially appears promising, but tests on aging and performance in steam are necessary.

TABLE 3.VII. Retention of EZemental Iodine on Sizver Membranes

\begin{tabular}{|c|c|c|c|c|c|}
\hline \multirow{2}{*}{$\begin{array}{l}\text { Mass } \\
\text { Loading, } \\
\text { mg } \\
\end{array}$} & \multirow{2}{*}{$\begin{array}{r}\text { Flow } \\
\text { Rate } \\
\text { ft } 3 / \mathrm{min} \\
\end{array}$} & \multicolumn{4}{|c|}{ Percent Retained } \\
\hline & & Filters & $\begin{array}{l}\text { Three Silver } \\
\text { Membranes (a) }\end{array}$ & $\begin{array}{l}\text { Charcoal } \\
\text { Paper }\end{array}$ & $\begin{array}{l}\text { Charcoal } \\
\text { Bed } \\
\end{array}$ \\
\hline 0.5 & 0.013 & 1.4 & 98.5 & 0.1 & 0.01 \\
\hline 0.5 & 0.5 & 0.5 & 99.1 & 0.4 & 0.00 \\
\hline 0.5 & 1.0 & 0.4 & 98.8 & 0.7 & 0.00 \\
\hline 0.5 & 1.5 & 0.4 & 98.5 & 1.0 & 0.02 \\
\hline 0.5 & 2.0 & 0.4 & 99.1 & 0.2 & 0.20 \\
\hline 5.0 & 0.5 & 0.2 & 98.2 & 1.6 & 0.02 \\
\hline 5.0 & 1.0 & 0.2 & 98.1 & 1.6 & 0.08 \\
\hline 5.0 & 2.0 & 0.2 & 97.8 & 2.0 & 0.12 \\
\hline
\end{tabular}

(a) Selas Flotronies, 5 u pore size

TABLE 3.VIII. Retention of Elemental Iodine on Glassfiber Fizters

Percent Retained

\begin{tabular}{lllll}
$5 \mu g$ Loading & $\begin{array}{c}0.5 \mu g \\
\text { Loading }\end{array}$ & $\begin{array}{c}50 \mu g \\
\text { Loading } \\
\text { (Norma1) }\end{array}$ & $\begin{array}{c}500 \mu g \\
\text { Loading } \\
\text { (Norma1) }\end{array}$ & $\begin{array}{c}5000 \\
\text { Loading } \\
\text { (Norma1) }\end{array}$ \\
\hline
\end{tabular}

$\begin{array}{lrrrrrrr}\text { Ist Filter(a) } & 5.8 & 1.2 & 2.4 & 42 & 2.1 & 0.29 & 0.13 \\ \text { 2nd Filter } & 4.4 & 0.19 & 5.7 & 12 & 1.5 & 0.21 & 0.04 \\ \text { 3rd Filter } & 4.9 & 0.11 & 2.4 & \text { (b) } & 1.5 & \text { (b) } & \text { (b) } \\ 4 \text { th Filter } & 4.1 & 0.10 & 2.1 & \text { (b) } & 1.7 & \text { (b) } & \text { (b) } \\ \text { 6 Ag screens } & 74.3 & 94.0 & 77.7 & 33 & 93 & 99.1 & 98.2 \\ \text { Ag membrane } & 3.9 & 3.9 & 7.6 & 10.1 & 5.0 & \text { (b) } & (\text { b) } \\ \text { AC paper } & 2.4 & 0.4 & 3.1 & 3.1 & 2.0 & 0.39 & 1.5 \\ \text { Charc. bed } & 0.1 & 0.1 & 0.1 & 0.07 & 0.1 & 0.00 & 0.02\end{array}$

(a) Gelman type A. Some of the retention of the first filter may be due to particulate-associated iodine.

(b) Not included in the Maypack.

(c) Carrier gas: air, $30^{\circ} \mathrm{C}, 40 \% \mathrm{R}$. H., $0.5 \mathrm{ft} \mathrm{f}^{3} / \mathrm{min}$ for $6 \mathrm{~min}$. 


\section{Maypack Cluster Performance}

R. H. Bond and J. D. McCormack

Gas phase aerosol samples are taken from containment atmospheres in the Aerosol Development Facility (ADF) by two procedures. The standard ADF method is to manually insert a Maypack into the vessel through an airlock, draw the desired volume of gas through 'the sampler, then remove it for immediate analysis. The Maypack is preheated to about $20{ }^{\circ} \mathrm{C}$ higher than the containment tank temperature to prevent steam condensation. The Maypack has no inlet tube; gas enters directly into the body via a $3 / 8$ in. hole in the nose cone. This reduces unwanted plateout to an insignificant level.

This technique gives reliable results, but it is not suitable for extensive use in the CSE vessel, where the large size and complicated geometry make manual sampling impractical. Remotely operated clusters of Maypacks have been designed and 15 "Maypack Clusters" fabricated for use in the initial CSE aerosol transport tests. Each cluster has 12 Maypacks identical to the ADF type except that an inlet check valve has been added.

Each Maypack has its own solenoid valve so that flow time $c$ an be controlled from the laboratory. The clusters will hang at various elevations and radii within the CSE vessels; the Maypacks will be oriented vertically. Flow will be upwards through the check valve, Maypack, solenoid valve and then through a manifold, which serves all 12 Maypacks. A single Teflon tube connects the manifold of the cluster to the CSE vessel penetration. A stainless steel line (heated and insulated) connects the penetration to the laboratory flow control station, * consisting of a condenser, pressure reducing valve, freeze trap, rotameter, and flow control valve. Dry, aerosol-free air is finally vented to a vacuum system.

Cluster performance has been evaluated in several ADF tests by using both devices concurrently. The cluster was located so that the inlets were at the ADF vessel center. The standard manual ADF samples were taken 2 in. from the wall at the same elevation. Mechanical operation of the cluster and flow control station was good in all five tests, but the commercial check valves retained an excessive amount of aerosol--up to $80 \%$ of the entering iodine. Modifications such as removing springs reduced the plateout to $30-50 \%$, but this was still too high.

The purpose of the check valve is to prevent diffusion into the Maypack during the long period when the sampler is not in use but is still in the containment environment. Absolute tightness is not necessary. Furthermore, the containment pressure will normally be decreasing due to condensation of steam in pressure decay tests. This will aid in preventing unwanted inflow to the samplers. Therefore, rather crude check valves were fabricated which consisted of a 2 in. long, $1 / 4$ in. diam nipple with a free floating Teflon ball, $13 \mathrm{~mm}$ diam, in the Maypack nose cone.

\footnotetext{
* Thirty stainless steel lines and thirty flow control stations have been provided.
} 
Plateout on the ball and nose was reduced to an acceptable $10 \%$ level.

Figure 3.3 gives a typical example of how the remotely-operated cluster Maypacks compare with the manual ADF method. The experimental points are the sum of the analyses of the four components: filter, silver, charcoal paper, and charcoal bed. Plateout on inlet parts is not included for either type. The figure shows that early in the test no significant differences were evident; and the slopes of the curves were within $\pm 10 \%$ by either sampler. Later, after the concentration had decreased by two orders of magnitude, larger discrepancies appeared. One of the cluster Maypacks was not operated and served as a blank. It showed that small amounts of iodine and cesium entered the sampler through the check valve, probably by check valve "chugging" during slight pressure variations in the nominal constant-pressure test. If the blank is subtracted from the cluster measurements, the two sampler types agree quite closely. The conclusion reached is that the remotely operated CSE Maypack clusters will give sufficiently accurate results, but correction is necessary for refinement of late-run samples.

Extended Duration Melting of Zircaloy-Clad $\mathrm{UO}_{2}$

J. D. McCormack

The CSE aerosol transport tests will use a long-term release of simulated fission products in some cases. Release periods of up to 5 hrs are desirable. Continuous melting of unirradiated Zircaloy-clad $\mathrm{UO}_{2}$ will be required during these periods.

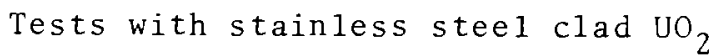
in a steam-air sweep gas were made for 2 hr with no evidence that considerably longer periods were not possible. A recent test with Zircaloy-clad $\mathrm{UO}_{2}$ in an air sweep gas was only partially successful, however. With increasing time, more power was required from the high frequency generator to maintain temperature. After $205 \mathrm{~min}$, the heater circuit breaker tripped and coupling was lost. Postmelt analys is showed that the melt residue had an average oxygen-to-uranium ratio of 2.5 , corresponding to $75 \% \mathrm{U}_{3} \mathrm{O}_{8}$ and $25 \% \mathrm{UO}_{2}$. The oxidation of the $\mathrm{UO}_{2}$ evidently resulted in decreased electrical conductivity of the melt material. The quartz furnace tube was undamaged.

Longer melting periods using Zircaloy-clad $\mathrm{UO}_{2}$ may be possible by preventing oxidation by either using an oxygen-deficient sweep gas or keeping the melt at higher temperatures.

Coolant Blowdown Studies

Blowdown Studies outside the

Containment Vesse 1

R. T. Allemann and C. H. Henager

To accelerate the schedule for the overall CSE program, we have installed the reactor simulator vessel in a test stand outside the CSE containment vesse1s. This permits blowdown tests in the outside test stand concurrently with aerosol and leakage tests in the containment vessels.

The blowdown tests outside contain ment provide opportunity for addi tional work under improved conditions of access to the vessel for installation and repair of sensors and for experimental modifications. In 


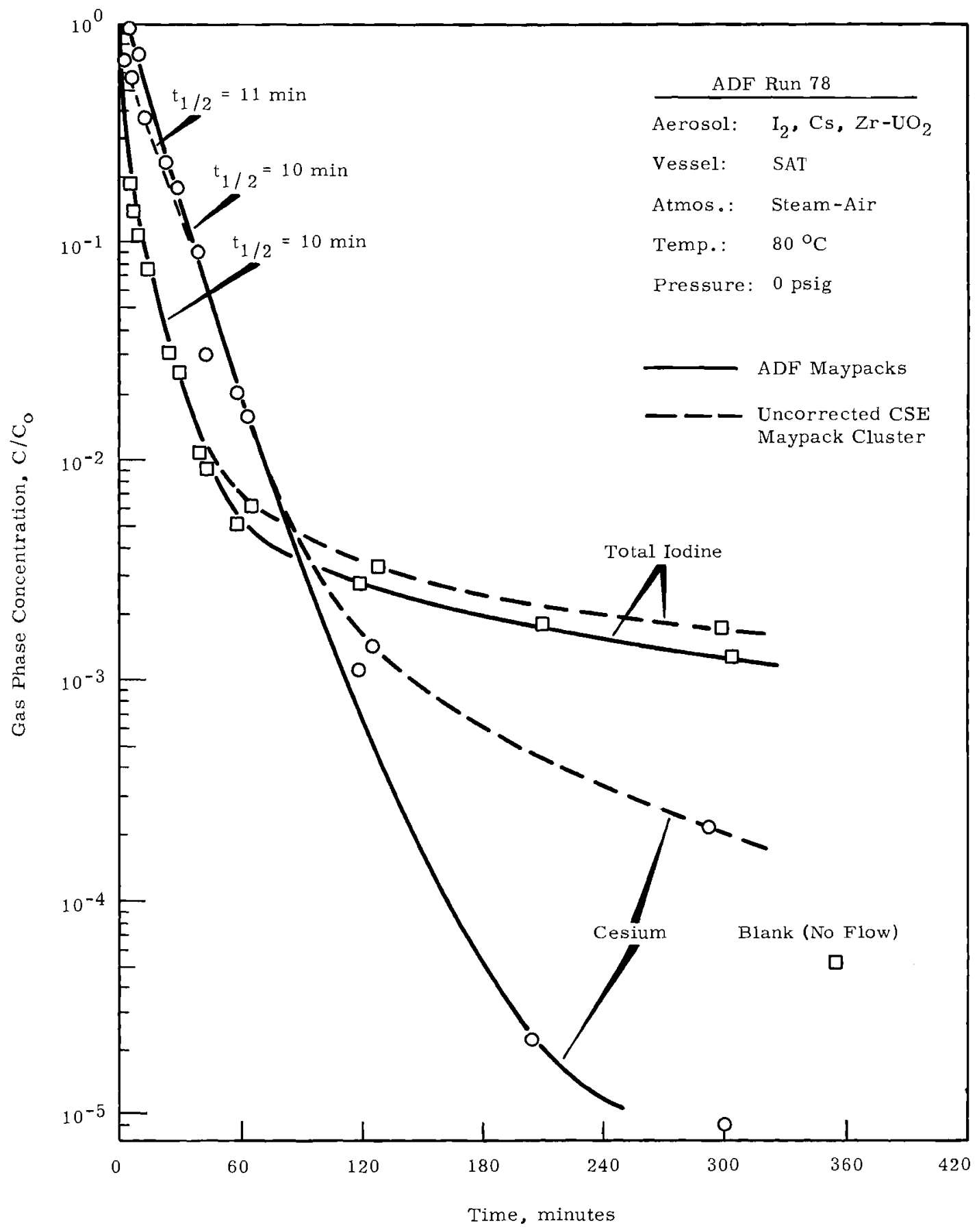

FIGURE 3.3. Comparison of CSE and ADF Maypack Samplers 
addition, there is increased interest in acquiring 1 arge scale experimental data to permit testing analytical techniques. The testing of these techniques will provide and verify detailed and sophisticated analyses of both the thermal and mechanical effects on the reactor vessel internals during the blowdown transient. Aspects of particular interest include mechanical damage to the core or to the emergency cooling system which might interfere with or prevent adequate functioning of this emergency cooling system in the event of a major loss-of-coolant accident. At the end of a period of concurrent testing for the blowdown and aerosol transport phases of the CSE program, the reactor simulator vesse1 will be removed from the outside test stand and installed inside the CSE containment vesse1.

The blowdown test series will start as simple no-core blowdowns of the liquid contained in the reactor simulator vessel through variously sized orifices at various initial conditions. The general arrangement of the reactor vessel in the framework and the attached instrumentation is shown in Figure 3.4. The function of each of the numbered instrumentation groups is as follows.

1. Load cell measures weight of the vessel and its contents during blowdown.

2. Thrust load cells measure reaction force on the vessel supports as result of the blowdown.

3. Liquid level gage (Time domain reflectometer) measures liauid level in simulator versus time.
4. Temperature probes measure temperature of the fluid in the vessel and discharge pipe.

5. Pressure sensors measure the pressure of the fluid in the vessel and discharge pipe.

6. Densitometer measures the void fraction of the liquid-steam mixture which flows through the blowdown nozzle versus time.

7. Impact pressure sensors measure the impact pressure of the fluid jet.

Subsequent to the no-core series, a simple orifice plate will be installed to provide a controllable flow resistance within the vessel volume. Figure 3.5 shows the configuration of the reactor simulator vessel with the simple orifice plate. The plate is designed so that later additions can be made to represent the internal arrangements in PWR and BWR designs. Figures 3.6 and 3.7 are sketches showing the additions and blowdown nozzle positions which are used to achieve simulation of a given reactor type and particular blowdown location. For example, in Figure 3.6, the core barrel addition to the original plate is shown with two different orientations. With the opening in the barrel aligned with the blowdown nozzle, an outlet line break is represented; and fluid escapes upward through the core. If the core barrel opening is not in 1 ine with the blowdown nozzle, an inlet line break is represented; and flow is down through the core and up the annulus between the barrel and the reactor vesse1. In both cases, the same upper blowdown nozzle on the vessel is used. 


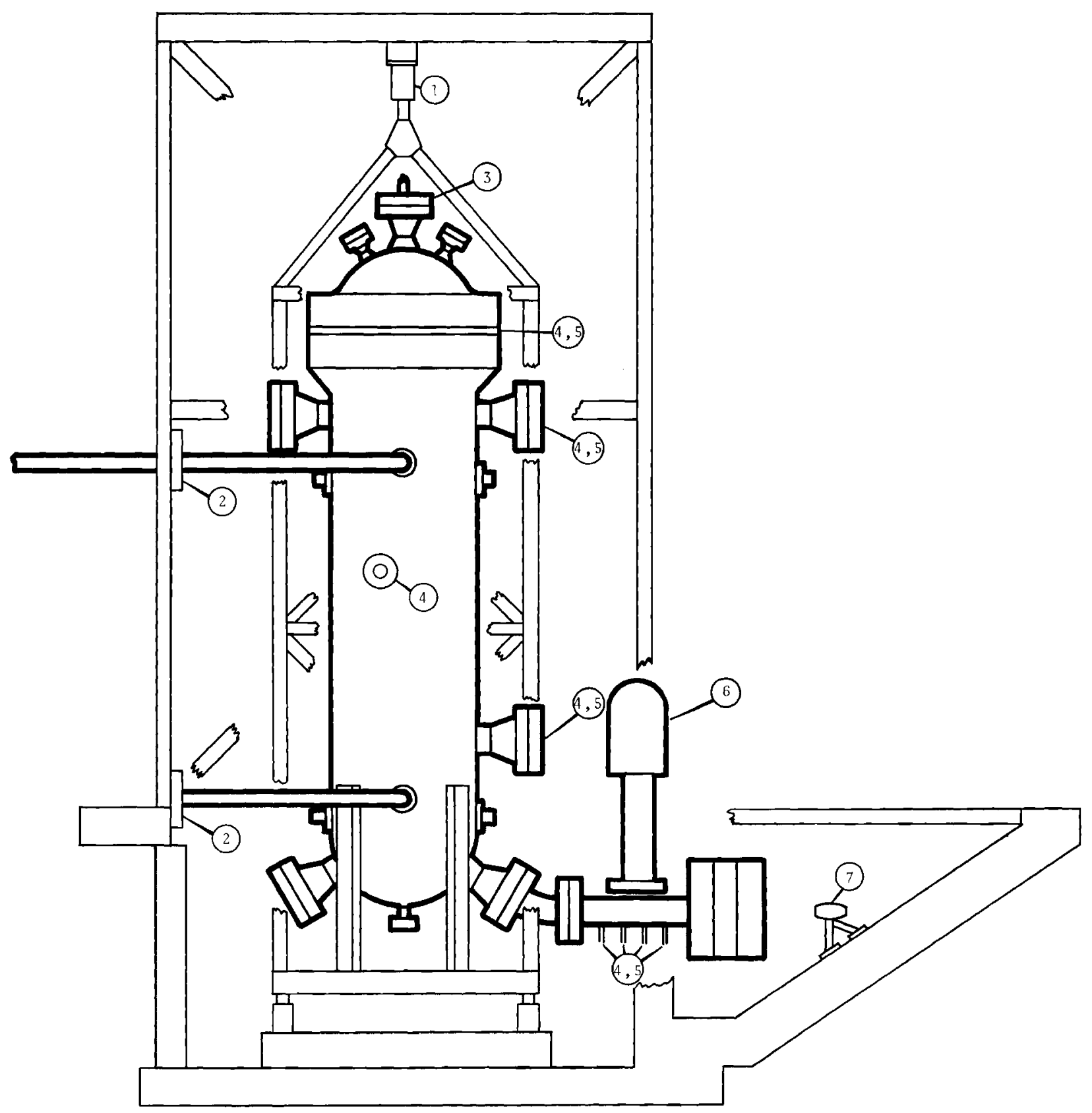

FIGURE 3.4. CSE Reactor Vessel, 277T 
Referring to Figure 3.7 , the steam line break is represented using the top blowdown nozzle, and the recirculation line break using the middle nozzle. The simulated fuel element assemblies will initially consist of lengths of tubing proportioned to give reasonably scaled flow areas. The intent is to begin with simple configurations and progress in stepwise fashion to more complex arrangements more closely representative of the complicated structures and flow paths of actual reactors.
The pressures, flow rates, and other measured data will be compared with the values predicted by mathematical models. As results are analyzed, the need for including further details will be determined.

Construction forces completed the installation of the blowdown facilities and satisfactorily performed the acceptance test procedures. The operational staff started calibration of the process instrumentation and the installation and calibration of the experimental sensors required for the initial blowdown series.

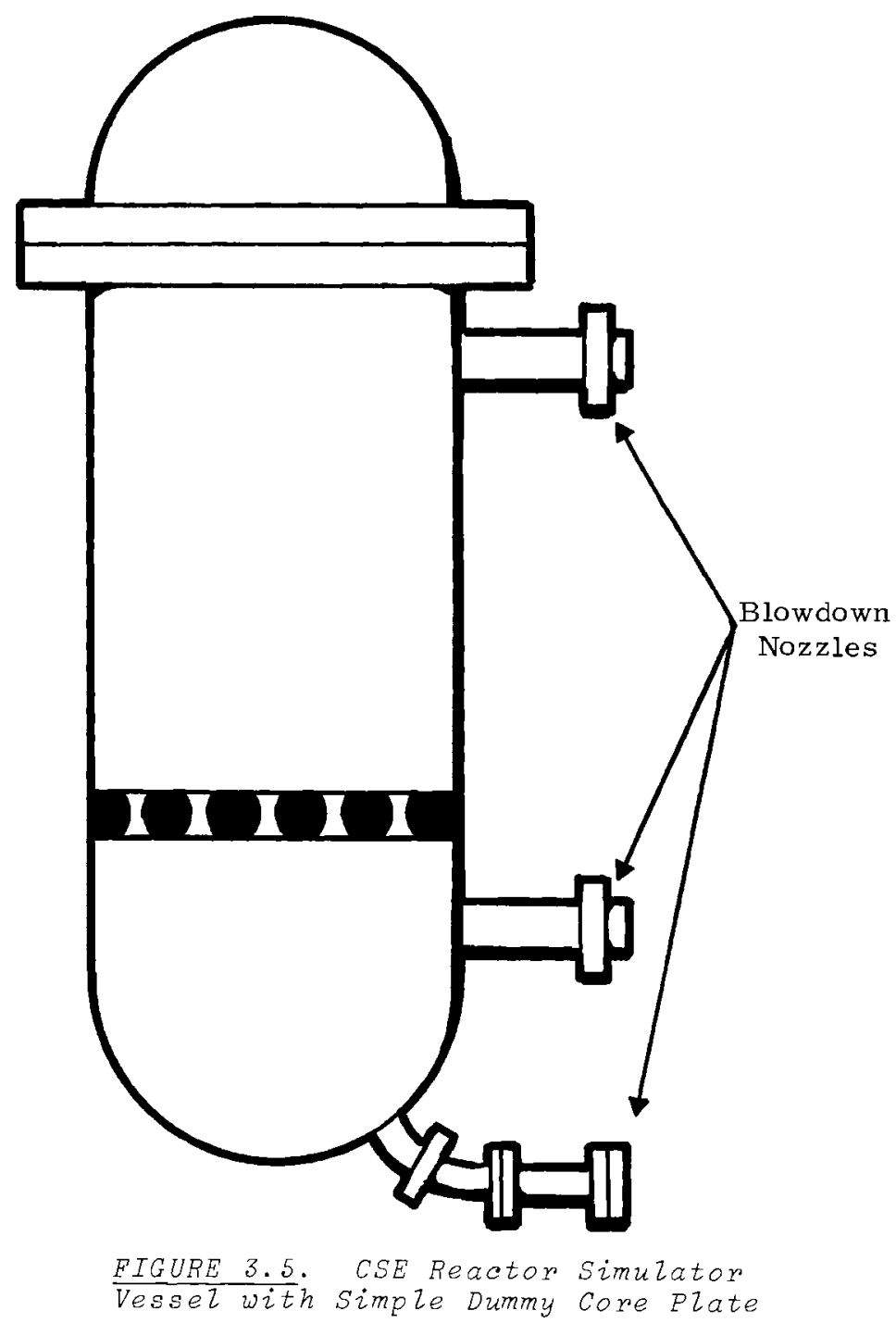




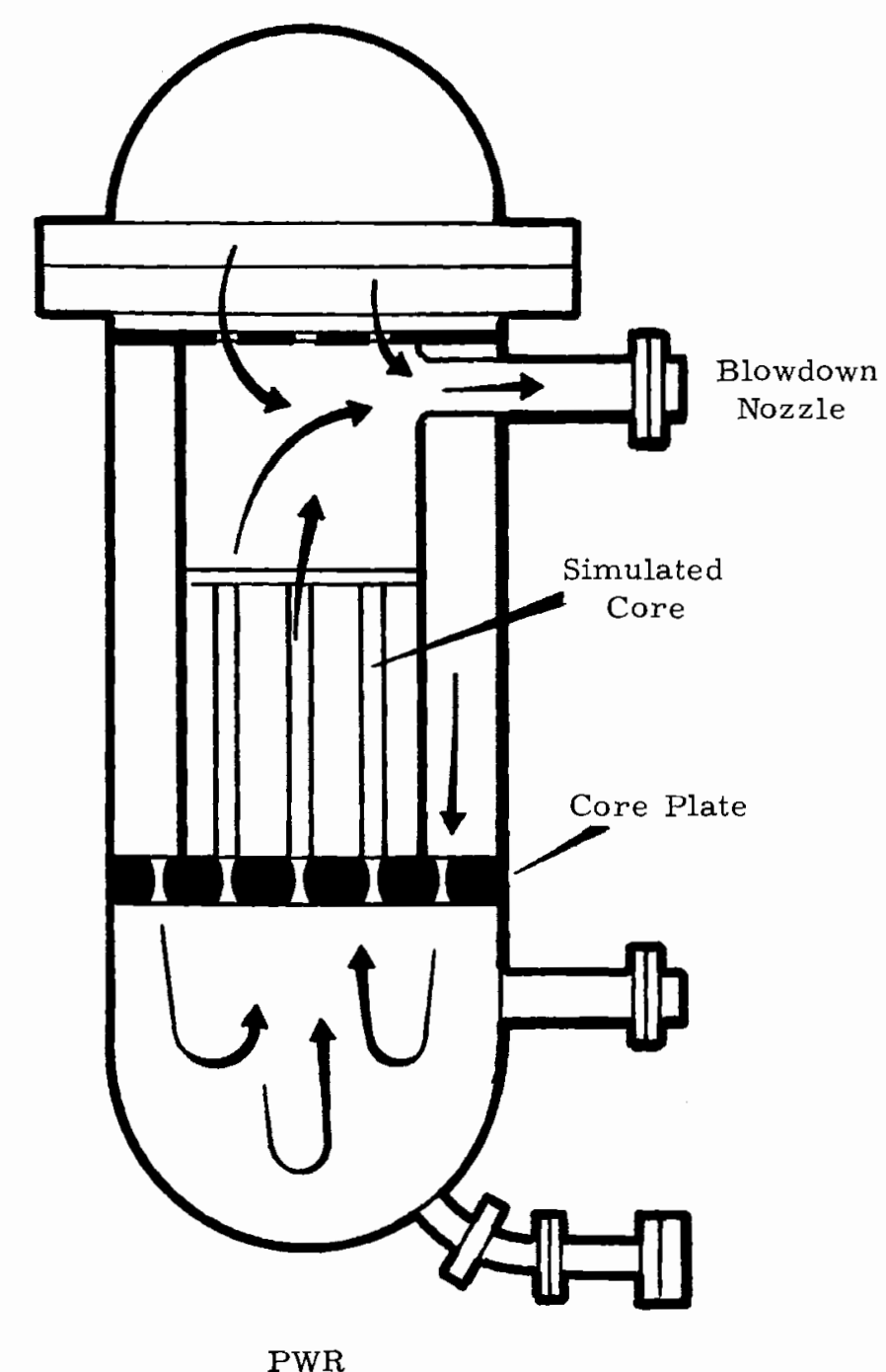

Outlet Break Simulation

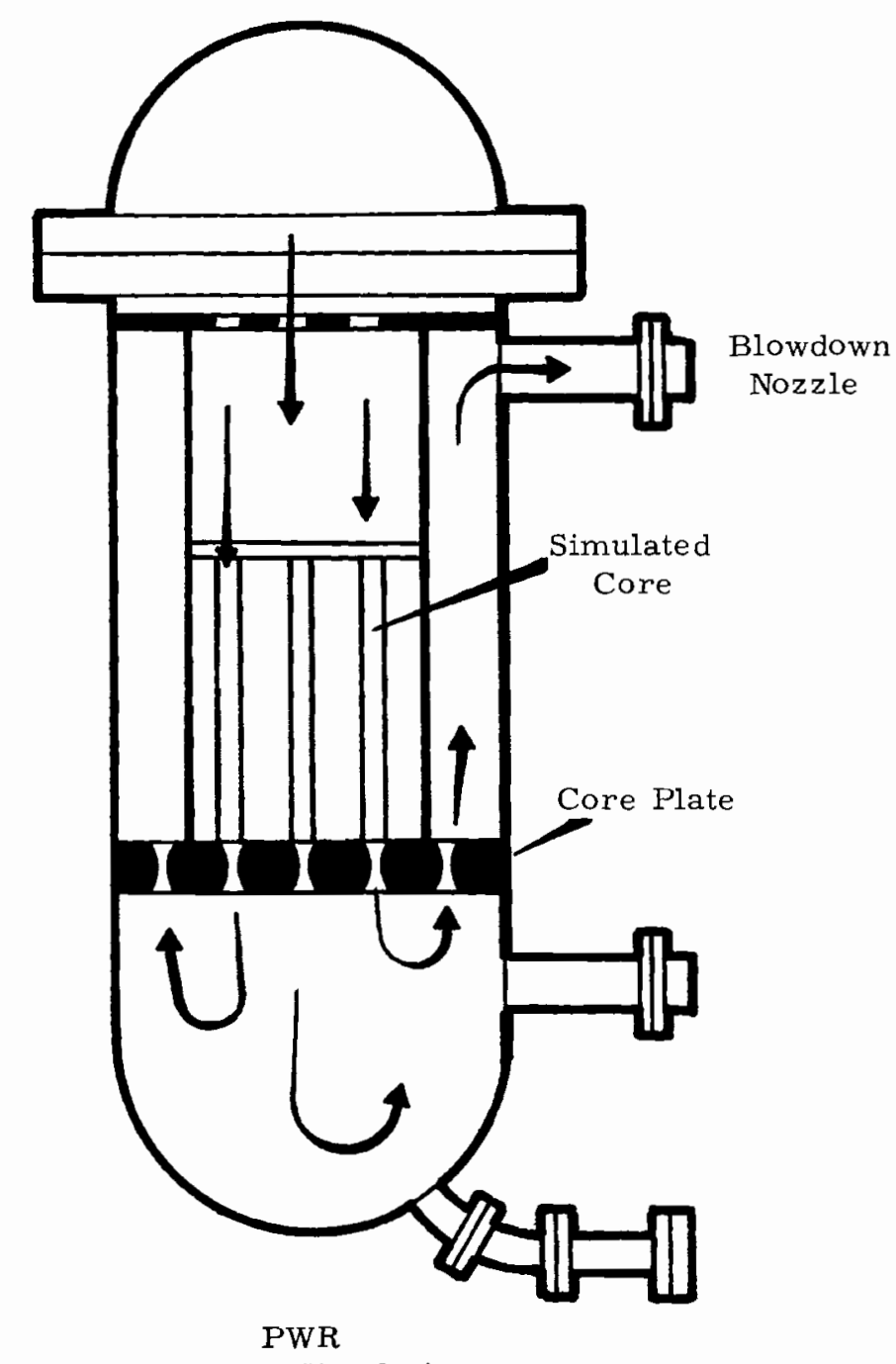

Inlet Break Simulation 


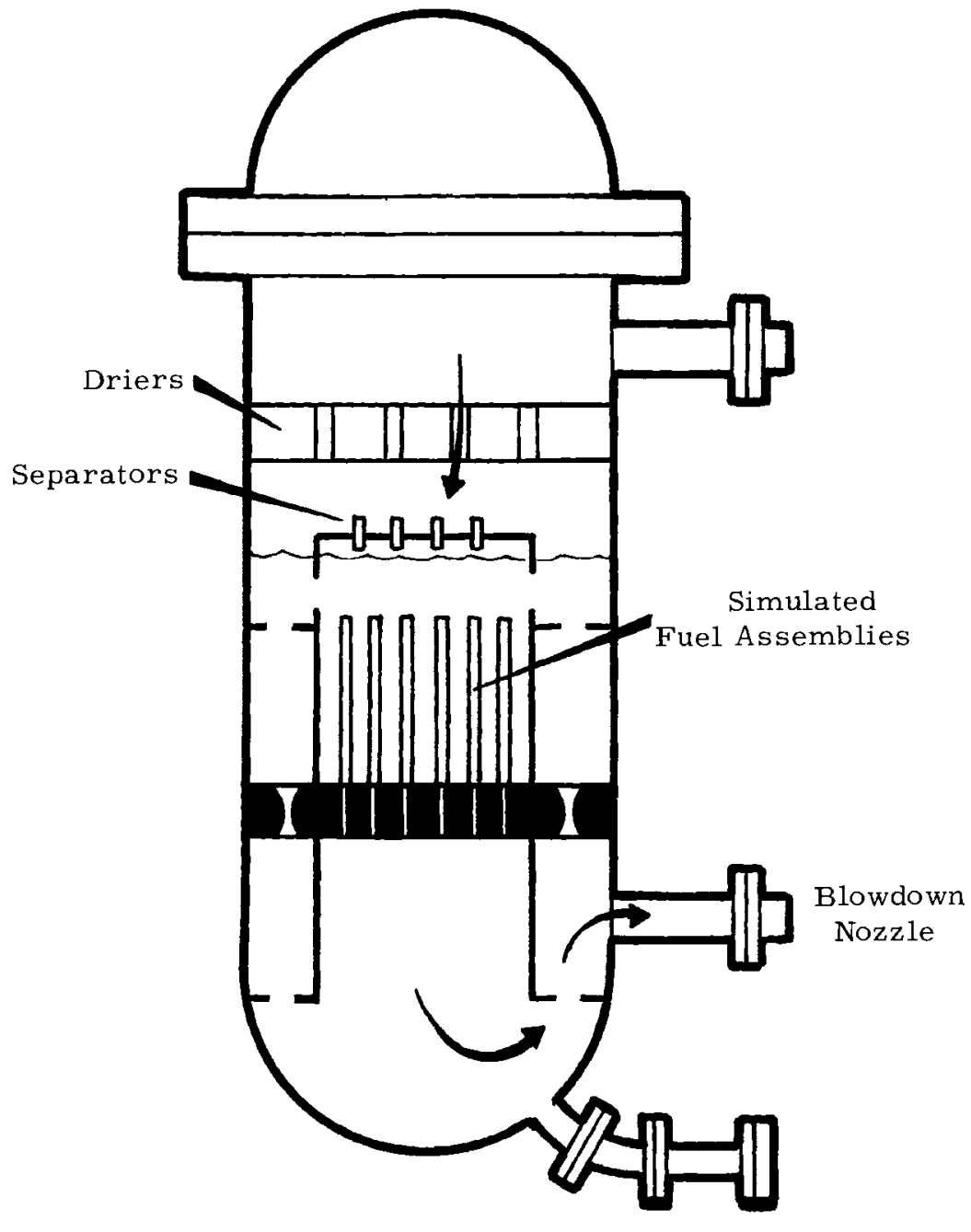

BWR

Coolant Loop Break Simulation

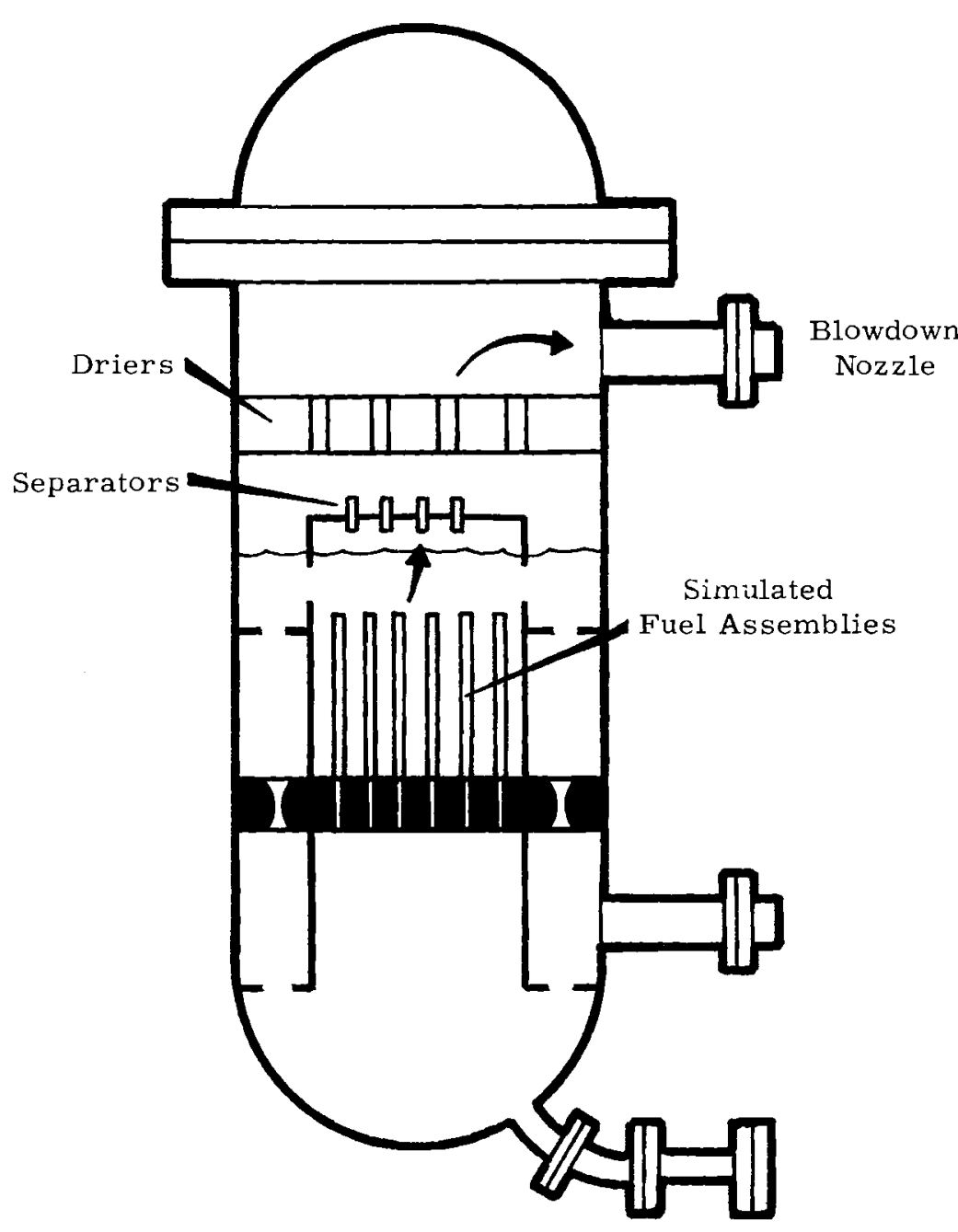

BWR

Steam-Outlet Break Simulation 


\section{FISSION PRODUCT AEROSOL CONTROL}

L. C. Schwendiman and L. L. Burger

Removal of Organic Iodides with

Hydrazine Sprays

L. C. Schwendiman, and J. Mishima

Following a serious reactor accident, . volatile and gaseous fission products will be released to the containment volume. A fraction of the radioactive fission product iodine released is expected to be in the form of methyl iodide; this compound is more difficult to remove with the usual iodine traps than is the molecular iodine.

A possible method of reducing the airborne concentration of iodine and its organic compounds is to form soluble nonvolatile compounds of iodine through gas or liquid phase reactions. One concept for utilizing the reactive compounds is to spray solutions of them through the containment atmosphere. One such reactive compound is hydrazine with which both iodine and methyl iodide will react to form water-soluble compounds. It is the purpose of this study to investigate the feasibility of using hydrazine sprays to remove methyl iodide from postaccident atmospheres. The reaction kinetics and spray removal efficiencies are to be investigated and the overall incentives and design criteria are to be determined.

The effectiveness of hydrazine sprays was demonstrated in runs prior to this reporting period using a $4 \mathrm{ft}$ tall by 14 in. diam chamber. Removal of greater than $98 \%$ of 1 abeled methyl iodide was achieved with a fine spray of $5 \%$ hydrazine- $5 \%$ ammonium hydroxide solution in about three hours of spraying. various other conditions were also studied with generally promising results.

During the current reporting period a much larger aerosol chamber (4 ft diam by $10 \mathrm{ft}$ tall) was given final shake-down tests preparatory to initial spray experiments. The chamber is constructed of stainless steel, and has provisions for a single spray nozzle near the top on the tank centerline. The sprayed liquid can be collected in separate annular rings to establish the spray versus wall efficiency for removal. Insulated tank walls can be heated to minimize steam condensation during the initial stages of the experiment. Sampling, viewing, and tracer insertion ports are provided.

A study was completed of the droplet size distribution, the spray uniformity, and the fraction of spray reaching the wall for four nozzles to be used in the chamber. A technique for catching droplets and sizing them was developed and utilized in this study. The number mean diameter ranged from about 160 to $270 \mu$, with the spectrum ranging to droplets over $750 \mu$ in diameter. Droplet sizes will be needed to help determine spray efficiency as a function of drop size.

Two spray runs were completed in the large aerosol chamber. The conditions for the first run are given in Table 3. IX.

The removal from the air was exponential with time. Removal of $90 \%$ under the conditions of the run would have required about $6 \mathrm{hr}$ of spraying. The removal efficiency of the. hydrazine spray under the conditions of the experiment was considered very satisfactory when compared with 
earlier results with the 114 liter aluminum chamber. Surface-to-volume ratio of the larger chamber is about $1 / 4$ that of the smaller chamber, the size distribution of droplets in the run was much more coarse, and the ratio of liquid available to volume of gas is about $1 / 2$ to $1 / 4$ that used in the earlier experiments. The spray drop residence time in the larger chamber is probably longer than in the smaller chamber due to the greater distance of fall. A half-time of removal of $73 \mathrm{~min}$ was found in this run compared to $25 \mathrm{~min}$ for the run in the smaller chamber under comparable conditions.

In the second experiment (HS-2), a different spray nozzle was used and hydrazine concentration was $6 \%$ by weight. Table 3.X gives the essential data for this run.

TABLE 3.IX. Operating Conditions for $H \bar{S}-1$

\begin{tabular}{|c|c|}
\hline Atmosphere: & Ste am-Air \\
\hline $\begin{array}{l}\text { Methyl iodide } \\
\text { concentration: }\end{array}$ & $0.09 \mathrm{mg} / \mathrm{m}^{3}$ \\
\hline Iodine concentration: & \\
\hline $\begin{array}{l}\text { Spray composition: } \\
\text { Spray volume }\end{array}$ & $5 \% \quad \mathrm{~N}_{2} \mathrm{H}_{4}-5 \% \quad \mathrm{NH}_{4} \mathrm{OH}$ \\
\hline recovered: & 19.81 iters \\
\hline Nozzle used: & $\begin{array}{l}\text { Spray System's } \\
\text { Hydraulic } \\
\text { Atomizing } \\
\text { Nozzle }\end{array}$ \\
\hline $\begin{array}{l}\text { Spray drop size } \\
\text { distribution: }\end{array}$ & 80 to $400 \mu$ \\
\hline Spray flow rate: & $\begin{array}{l}0.83 \mathrm{gal} / \mathrm{min} \\
\text { start to } \\
0.56 \mathrm{ga} 1 / \mathrm{min} \\
\text { end }\end{array}$ \\
\hline $\begin{array}{l}\text { Duration of run: } \\
\text { Chamber temperature }\end{array}$ & $180 \mathrm{~min}$ \\
\hline at start: & $92{ }^{\circ} \mathrm{C}$ \\
\hline $\begin{array}{l}\text { at end: } \\
\text { Distribution of active } \\
\text { methyl iodide } \\
\text { accounted for: }\end{array}$ & $49^{\circ} \mathrm{C}$ \\
\hline Spray Liquid: & $70.3 \%$ \\
\hline Airborne: & $29.7 \%$ \\
\hline
\end{tabular}

This run gave high efficiency methyl iodide removal and further demonstrated that hydrazine may prove useful. Many tests will yet be required to establish the optimum parameters and to achieve a full understanding of the process.

The Hydrazine-Methyl Iodide Reaction

L. L. Burger, R. A. Hasty

The objective of this phase of the study is to determine the reaction kinetics between hydrazine and methyl iodide, and to establish reaction models to assist interpretation of the spray chamber results. Work during earlier periods had shown that the reaction was primarily a gas-liquid phase reaction rather than a gas-phase reaction. When an air-1iquid interface was present in a small closed system, methyl iodide was lost to the liquid

$\frac{\text { TABLE } 3 \cdot X}{\text { for HS-2 }}$ Operating Conditions

Atmosphere: Methyl Iodide concentration: Iodine concentration: spray composition:

Spray volume recovered:

Nozzle used:

Spray drop size:

Spray flow rate:

Spray drop size

distribution:

Duration of run:

Chamber temperature

at start:

at end:

Distribution of active methyl iodide accounted for:

Spray liquid:

Steam-Air

$0.09 \mathrm{mg} / \mathrm{m}^{3}$

0

$6 \%$ hydrazine, $6 \%$ ammonium hydroxide

45 liters Bete Fog Nozzle

$360 \mu \mathrm{mass}$

median

diameter

ح2.5 gal $/ \mathrm{min}$

$80-750 \mu$

$360 \mathrm{~min}$

$96{ }^{\circ} \mathrm{C}$

$44^{\circ} \mathrm{C}$

Ai rborne:
$99 \%$

$1 \%$ 
at a rate proportional to the surface and inversely proportional to the gas volume. The rate was proportional to the methyl iodide concentration. The rate was faster at elevated temperatures, but not markedly so.

- During the current reporting period the hydrazine-methyl iodide reaction was studied using a flow system. The gas was passed through a solution in the form of small bubbles. These studies were designed to test the hypothesis that the removal of methyl iodide would be rapid when the areas of contact between gas and solution were large. The time of contact of gas and solution in the flow system was less than a second and was proportional to the volume of solution. The interfacial area of contact was of the order of $60 \mathrm{~cm}^{2} / \mathrm{cm}^{3}$ of gas. The efficiencies of methyl iodide removal are shown in Table 3.XI for several of the solutions which were examined.

The results of the flow system can only be compared in a qualitative way to the model proposed from prior work since neither the length of time of

$\frac{T A B L E}{\text { Flow System }} \frac{\text { S.XI. }}{\text { Summary of Results of }}$

Conc. Volume Flow Rate Percent $\mathrm{CH}_{3} \mathrm{I}$ Length $\mathrm{N}_{2} \mathrm{H}_{4}$ (a) Test of Carrier Retained by of Flow, - wt: Soln.,m1 Gas, m1/min Solution, \% min

\begin{tabular}{ccccc}
33.6 & 25 & $\sim 12$ & 96.5 & 100 \\
33.6 & 24 & $\sim 30$ & 95 & 100 \\
0 & 25 & 212 & 5.8 & 100 \\
33.6 & 20 & 8.6 & 95.2 & 220 \\
3.4 & 20 & 8.6 & 80.4 & 100 \\
3.4 & 20 & 8.6 & 78.4 & 220 \\
3.4 & 40 & 8.6 & 94.6 & 110 \\
3.4 & 40 & 8.6 & 93.6 & 220 \\
3.4 & 40 & 8.6 & 93.3 & 315 \\
1.0 & 40 & 8.6 & 81.8 & 250 \\
1.0 & 40 & 37.6 & 40.7 & 135 \\
1.0 & 40 & 37.6 & 44 & 315 \\
\hline (a) $(N a O H)$ & $=0.050 N$, Temp. & &
\end{tabular}

(a) $(\mathrm{NaOH})=0.050 \mathrm{~N}$, Temp. $222^{\circ} \mathrm{C}$ contact nor the interfacial contact area are known except by estimation.

It should be noted that, by increasing the time of contact between the gas and solution, much higher removal efficiencies of methyl iodide are possible. The range of efficiencies reported in Table 3 .XI were obtained by design to enable interpretation of the results.

The flow technique can be used as a method for the quick evaluation of a solution in comparison to solutions which have been previously examined. This technique also appears to be an excellent one to predict the behavior of solutions in the spray chamber in comparison to solutions which have already been tested in the spray chamber.

The homogeneous reaction of hydrazine and methyl iodide in an aqueous alkaline solution is being examined. Methyl iodide, tagged with $131_{I}$, is prepared by an exchange reaction. Analysis of the solutions is performed in the following manner: the iodide ion is removed from solution with a column of Dowex AG1x8,50-100 mesh resin $\left(\mathrm{Cl}^{-}\right.$form). It was demonstrated that amberlite $X A D-2$ resin removed methyl iodide from solution without removal of the iodide ion. By using these two resins, aliquots of reaction mixtures are separated and the fraction of iodide ion in the reaction mixture is determined from the amount of ${ }^{131} \mathrm{I}$ which is found in the separated fractions. The rate of disappearance of methyl iodide or the rate of appearance of iodide ion can be determined. One example of the results obtained thus far is shown in Table 3.XII. The 
TABLE 3.XII. Rate of Iodide Production

$\left(\mathrm{N}_{2} \mathrm{H}_{4}\right)=\underset{(\mathrm{NaOH})^{-}=0.050 \mathrm{M} ;}{0.021 \mathrm{M} ;}\left(0.07 \mathrm{~N}_{2} \mathrm{H}_{4}\right) ;$

$\left(\mathrm{CH}_{3} \mathrm{I}\right) \leq 0.0026 \mathrm{M} ;$ Temperature, $22{ }^{\circ} \mathrm{C}$

Reaction Time, min Fraction Iodide Ion

$\begin{array}{ll}0 & 0.08 \\ 2 & 0.125 \\ 10 & 0.472 \\ 20 & 0.685 \\ 30 & 0.776 \\ 40 & 0.758 \\ 60 & 0.839\end{array}$

principal problem encountered thus far is the loss of methyl iodide by volatilization when the solutions are sampled.
The completion of the examination of the kinetics of the solution reactions should be completed within the next quarter. The next phase of the problem to be examined will be either the determination of the effectiveness of alternative reagents for the removal and retention of methy 1 iodide or the determination of the rate and mechanism. of the gas phase reaction between hydra$z$ ine and methyl iodide. 


\section{PRESSURE BEARING COMPONENT EVALUATION AND MONITORING STUDIES}

R. G. Wheeler

CRACK DETECTION IN PRESSURE. PIPING BY

ACOUSTIC EMISSION

P. H. Hutton, H. N. Pedersen,

J. C. Spanner

- The Pacific Northwest Laboratory has in progress a program to develop a reactor pressure piping surveillance system to detect formation and/or growth of flaws by sensing the attendant acoustic emission (pressure waves) in the metal. Such a system will enhance nuclear safety by guarding against unexpected failure of piping due to causes such as long term radiation embrittlement, fatigue, stress corrosion cracking, etc. This program, sponsored by the Division of Reactor Development and Technology, USAEC, was initiated in February, 1966, and is currently scheduled for completion by July, 1969 .

During the quarter, a 2 in. wide by 1 in. thick by 14 in. 1 ong double cantilever beam (DCB) specimen of A-302-B carbon steel was tested at near cryogenic temperature $\left(-140^{\circ} \mathrm{C}\right)$ by the Metallurgy Department as a calibration test preliminary to a large scale test of a heavy section ( 3 in. thick) DCB specimen of the same material. As part of this test, detection of acoustic emission under the adverse environment of low temperature and liquid nitrogen vaporization was evaluated. Two types of transducers were used--an accelerometer and PZT-5 transducer.

The accelerometer was not satisfactory for this environment because of its case sensitivity to noise from the vaporizing liquid nitrogen. The PZT-5 transducer was not sensitive to noise from boiling nitrogen but the low temperature appeared to reduce the efficiency of the liquid couplant used (glycerine) to the point where on $1 y$ the stronger signals were detected. The signals detected were consistent with what past study would indicate is to be expected from a brittle fracture in carbon steel, i.e., a 100 to $120 \mathrm{kHz}$ signal corresponding to the estimated thickness resonance of the specimen and brief duration signal bursts $(\simeq 50 \mu \mathrm{sec})$ to indicate a transient pulse origin. Determination of a more suitable low temperature couplant to use with the PZT-5 transducer on the large specimen test is in progress. Obtaining good acoustic emission data from this test is considered particularly important in view of the current interest in defining unique properties of heavy section stee1s.

Two pressure vesse1 static burst tests have been performed as part of the preparation for investigating field application problems. The purpose was twofold--(1) to learn, before attempting to detect acoustic emission under simulated field conditions, of any unique response characteristics of a flaw growing in a cylindrical specimen from internal pressure as compared to that of a flat plate tensile specimen, and (2) to further signal analysis and characterization efforts. Analysis of test data is not yet 
complete but currently it appears that delineation of acoustic emission versus physical events is more distinct in the cylindrical specimens.

Figure 4.1 shows the burst test arrangement. The vessel was constructed of $3 \mathrm{in.}$ diam, $1 / 4$ in. wall, type A-106-B carbon stee1 pipe, 36 in. long with reusable, friction locked end closures. An initial flaw, $1 / 8$ in. wide by $11 / 2$ in. long, was milled about $85 \%$ of the way into the pipe wall. The remaining web at the bottom of the flaw was then cracked through by internal pressurization. The inside of the flaw area was 1 ined with a stainless steel patch and a neoprene seal plug to permit repressurization for flaw propagation. Crack propagation strain gauges were attached 1 in. beyond each end of the flaw to help identify crack movement with acoustic emission data.

Figure $4.2 \mathrm{~A}$ shows an oscilloscope panorama of burst test emission data from the PZT-5 transducer located nearest the crack together with the response of the strain gauges and a trace of the voice channel to identify load values. The crack extended a total of $17 / 8$ in. from one end of the flaw and $15 / 8$ in. from the other end. Acoustic emission activity is evident early in the pressure cycle $(50 \%$ of failure pressure). Emission from deformation of the metal around the original flaw appears at about $70 \%$ of failure pressure, and the emission data indicates that the flaw started to grow at about $90 \%$ of failure pressure. Judging from the response of the strain gauge, the flaw extended slowly, mostly in one direction, until an unstable condition was reached at which point it extended rapidly in both directions until it arrested due to depressurization. The emission rate curve in Figure $4.2 \mathrm{~B}$ shows good correlation between count rate and the test sequence. The profile is similar to that obtained from earlier DCB tests with similar. material; however, the response to crack movement is more pronounced in the vessel because the movement is more continuous.

The frequency content of the burst test data has not been completely analyzed. However, a preliminary spectrum analysis shown in Figure 4.3 demonstrates a definite change in frequency content as the test progresses, and the presence of significant components in the 20 to $30 \mathrm{kHz}$ range is obvious. This is consistent with earlier indications for a ductile fracture in carbon stee1. The data analyzed to produce these curves were derived from one of the PzT-5 transducers which has a frequency range up to $300 \mathrm{kHz}$. The spectrum curve is also typical for the other transducers.

A random check of signal arrival time at the various transducers on the burst test specimen showed that some of the signals originated at the end caps but most of those inspected originated at the flaw. Figure 4.4 shows some typical examples.

Hydraulic noise data were obtained from an operating reactor and a hydraulic test mockup as part of plant support work. This is significant to the acoustic emission program because hydraulic noise represents one of the more notable interference factors in detecting acoustic emission in the end application. In both instances, the system being monitored was a closed, pressurized loop. Flow velocities 


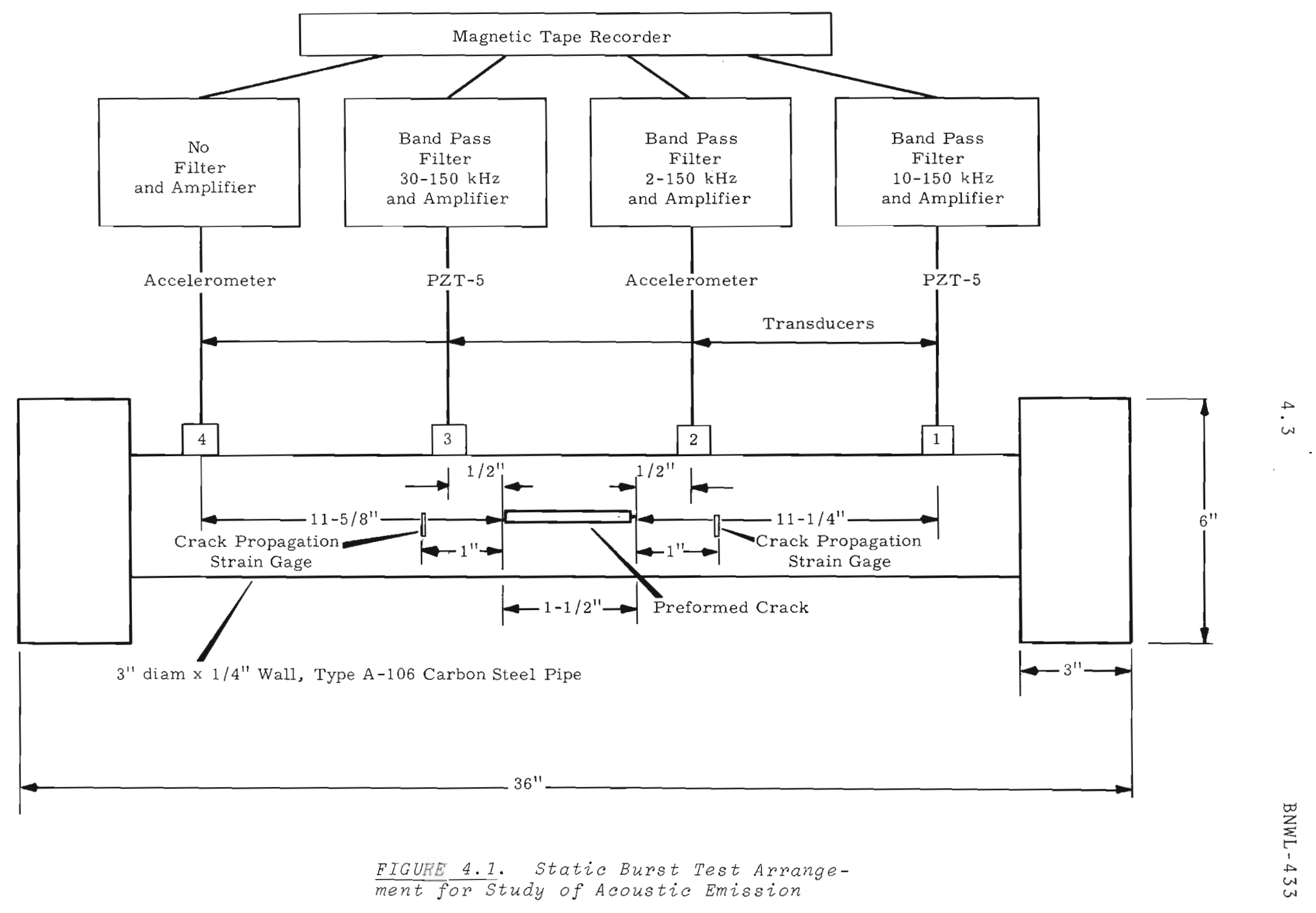




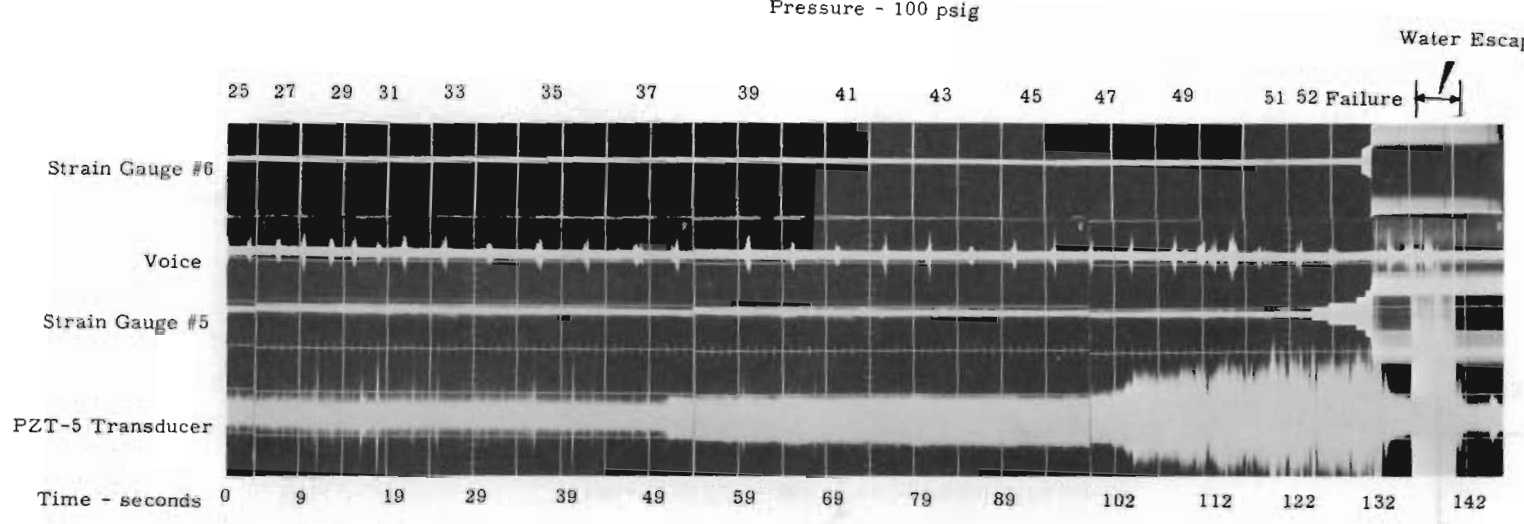

A. Oscilloscope Panorama of Data

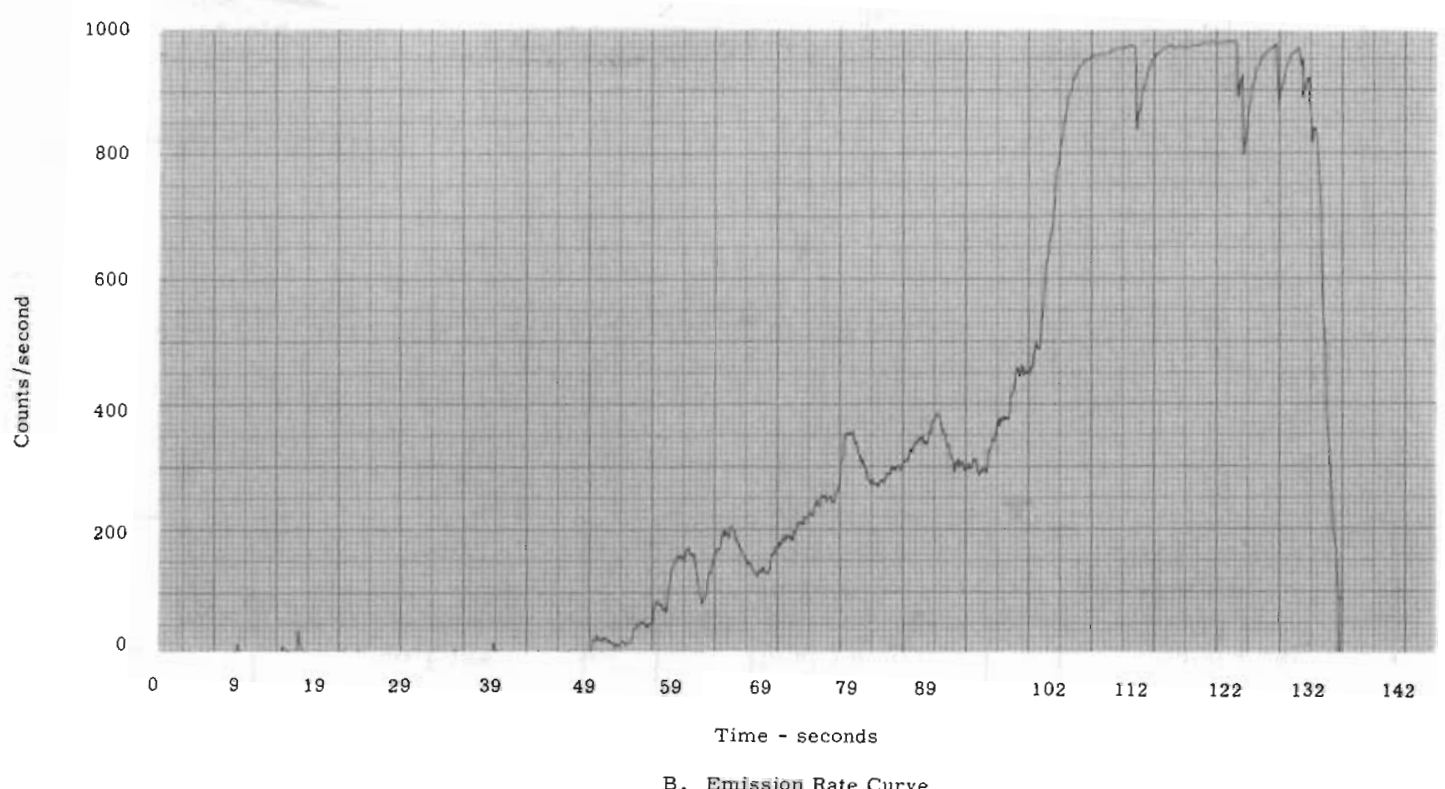

FIGURE 4.2. Compization of Data from

Static Burst Test of a 3 in. Diam $x$

$1 / 4$ in. Wall $x 36$ in. Long, Type

A-106-B Carbon Steel Pressure Vessel

(Ductile failure) 


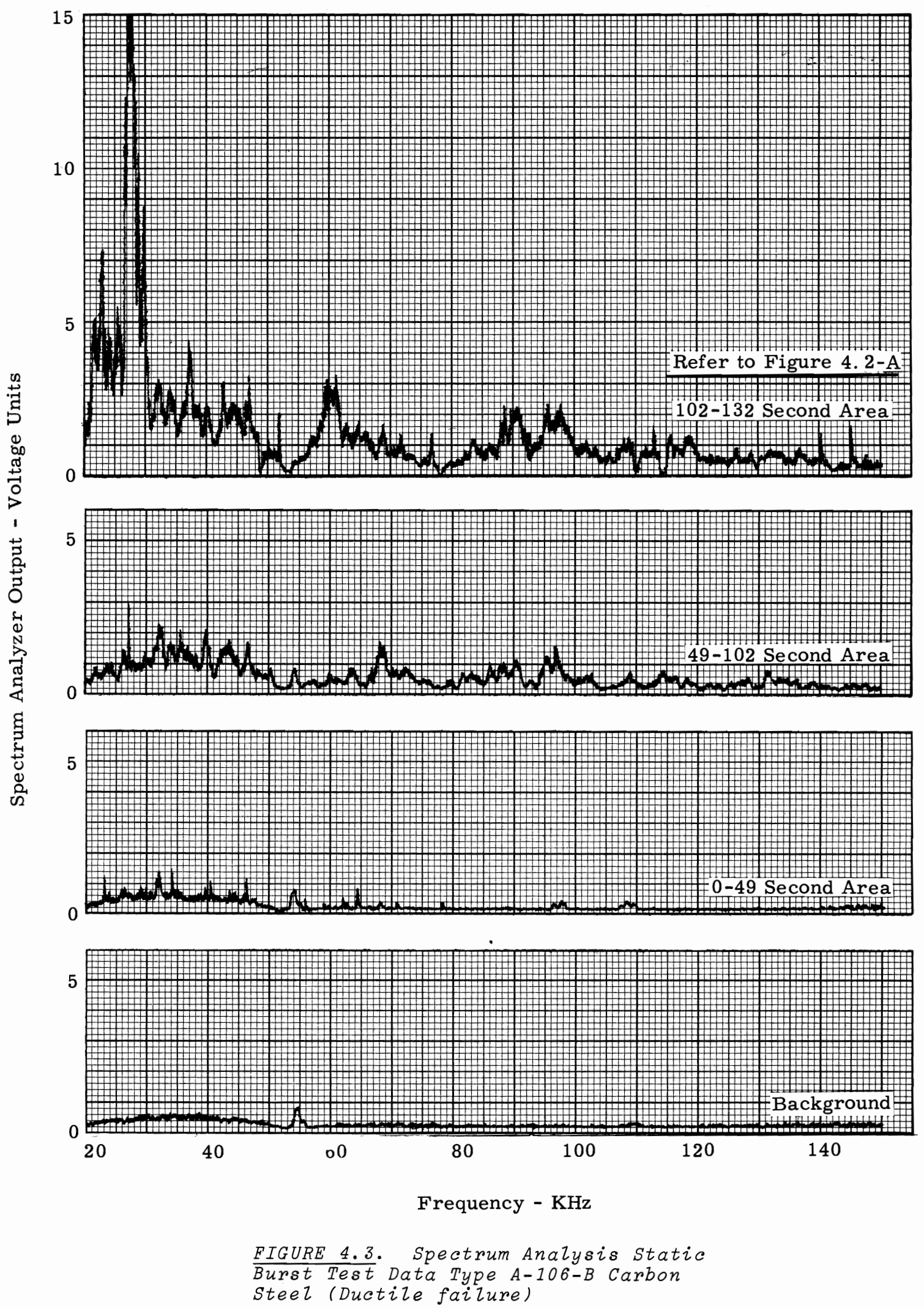




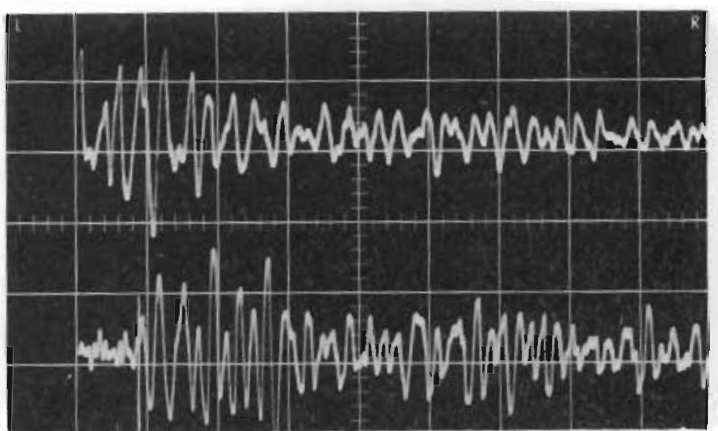

$0.85 \times 10^{-4} \mathrm{sec} \times 111 \times 10^{3} \mathrm{in.} / \mathrm{sec}=9.4 \mathrm{in}$. Sensor 3 to 4

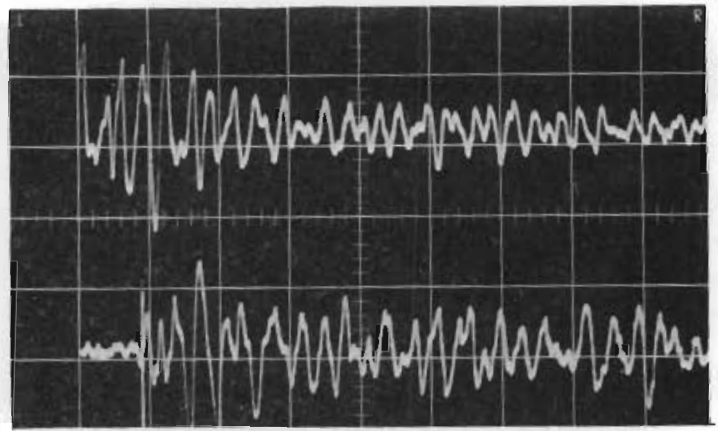

$0.9 \times 10^{-4} \sec \times 111 \times 10^{3} \mathrm{in} . / \mathrm{sec}=9.99 \mathrm{in}$. Sensor 3 to 1

Difference in Signal Travel Distance

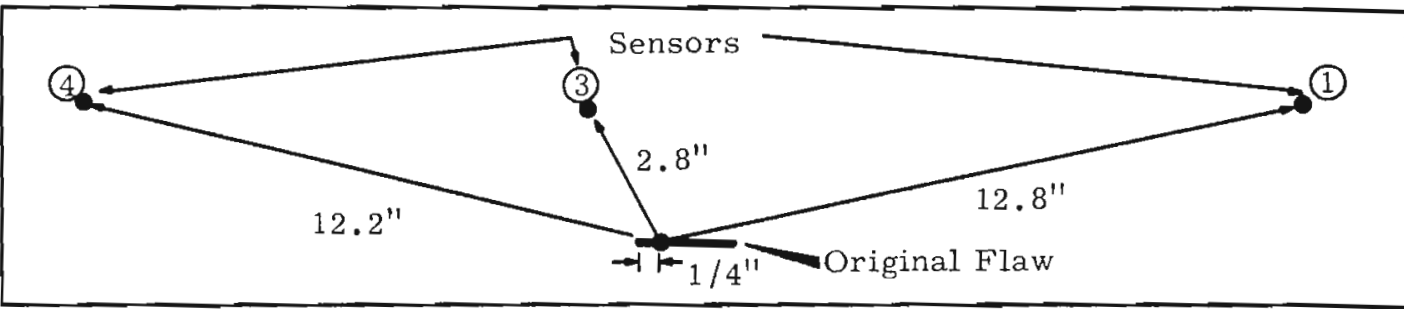

Location of Signal Source at 2800 psig

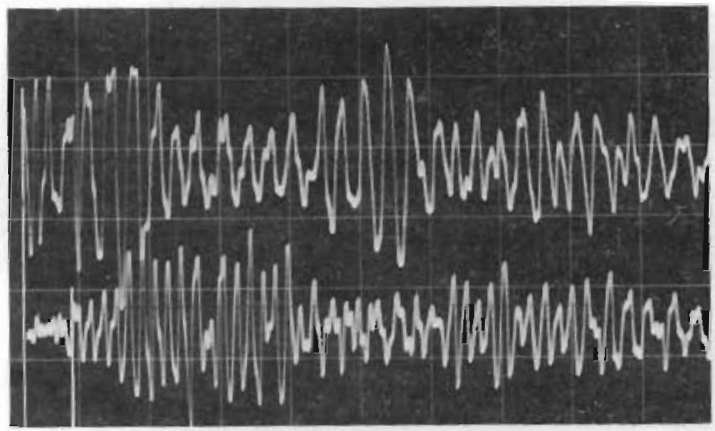

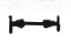

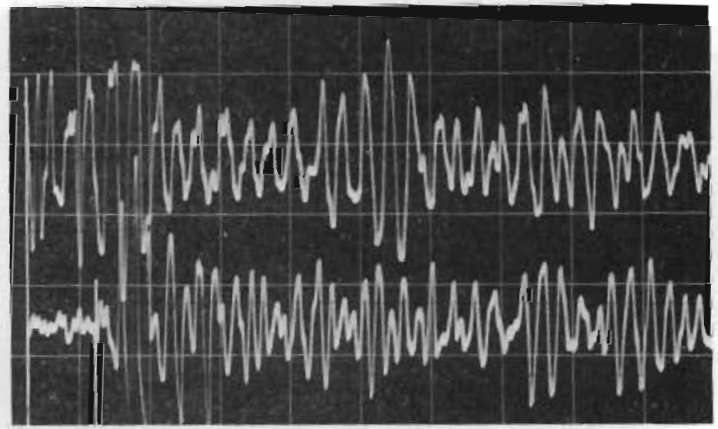

$\longrightarrow$

$0.75 \times 10^{-4} \sec \times 111 \times 10^{3} \mathrm{in} . / \mathrm{sec}=8.3 \mathrm{in} .1 .0 \times 10^{-4} \mathrm{sec} \times 111 \times 10^{-3} \mathrm{in} . / \mathrm{sec}=11.1 \mathrm{in}$. Sensor 3 to 4 Sensor 3 to 1

Difference in Signal Travel Distance

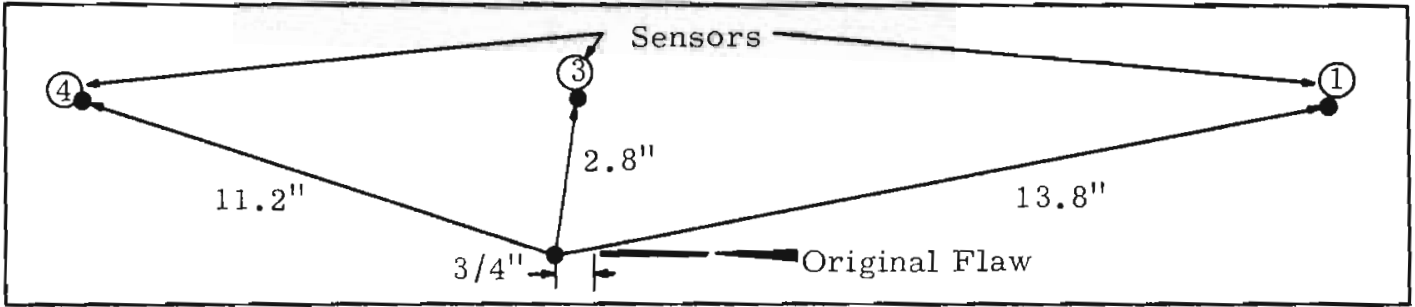

Location of Signal Source at 5000 psig

FIGURE 4.4. Examples of Signal Source Location from Static Burst Test Data (Refer to Eigure 4.2-A) 
ranged from 11 to $161 / 2 \mathrm{ft} / \mathrm{sec}$ and water temperature was in the 300 to $500{ }^{\circ} \mathrm{F}$ range. Pressure was sufficient to suppress boiling and cavitation. The spectrum analysis of the data in Figure 4.5 shows that essentially all of the - information is in the frequency range below $10 \mathrm{kHz}$. The data were analyzed on out to $150 \mathrm{kHz}$ and no higher frequency

' components were evident; therefore, the analysis shown in Figure 4.5 was limited to the range of $500 \mathrm{~Hz}$ to $20 \mathrm{kHz}$ to show the information in greater detail. This information provides specific supporting evidence for the contention that the higher frequency components of acoustic emission above $10 \mathrm{kHz}$ must be utilized for effective application of the phenomenon in a crack monitor system for use on reactors.

\section{SUBSIZE VESSEL FAILURE ANALYSIS}

D. R. Ireland

During the report period, tests were made to complete the fracture analysis of the unirradiated vesse 1 material so the analysis could be compared with results of tests on irradiated vessels; also, a preliminary evaluation of expected gamma heating of heavy section specimens in the SERF reactor was started.

Higher pressures were required to burst the miniature vessels, each containing an axially oriented artificial flaw, than were required to burst similar unirradiated specimens. This apparent increase in fracture toughness with irradiation is attributed to one or more of the following:

- Fracture toughness increases with irradiation.
- The method used to introduce an artificial crack may not be equivalent to a high-cycle, low-stress fatigue crack.

- The effect of increasing the yield strength, as in irradiation hardening, on fracture toughness calculations for biaxially loaded specimens is not adequately understood.

Impact energy absorption behavior of the unirradiated $A 212 \mathrm{~B}$ was evaluated and compared with the results of a modified drop weight transition temperature (DWTT) test. The DWTT test is similar to the drop weight test described in ASTM designation E208-63T except the DWTT tests used a 0.25 in. thick specimen cut from the wall of the subsize-vessel specimens. This DWTT specimen is a 1 in. wide quarter-round section with a 0.125 in. long $V$-notch crack starter on the inner surface. A weight is dropped on the outer surface and a crack is initiated at the V-notch. If the specimen temperature is less than the DWTT of the material, the crack will run to both edges of the 1 in. wide specimen. If the specimen temperature is greater than the DWTT of the material, the crack will not run to the edges of the specimen (Figure 4.6).

Charpy $V$-notch specimens were machined from the same lot of $A 212 \mathrm{~B}$ plate as used to make the subsize-vessel specimens. The variation in Charpy V-notch impact energy with temperature was measured and the results are shown in Figure 4.7 . The relative position of the DWTT on the impact energy curve is similar to the usually reported position of standard drop weight nil ductility transition (NDT) temperature on impact energy curves for this type of steel. 

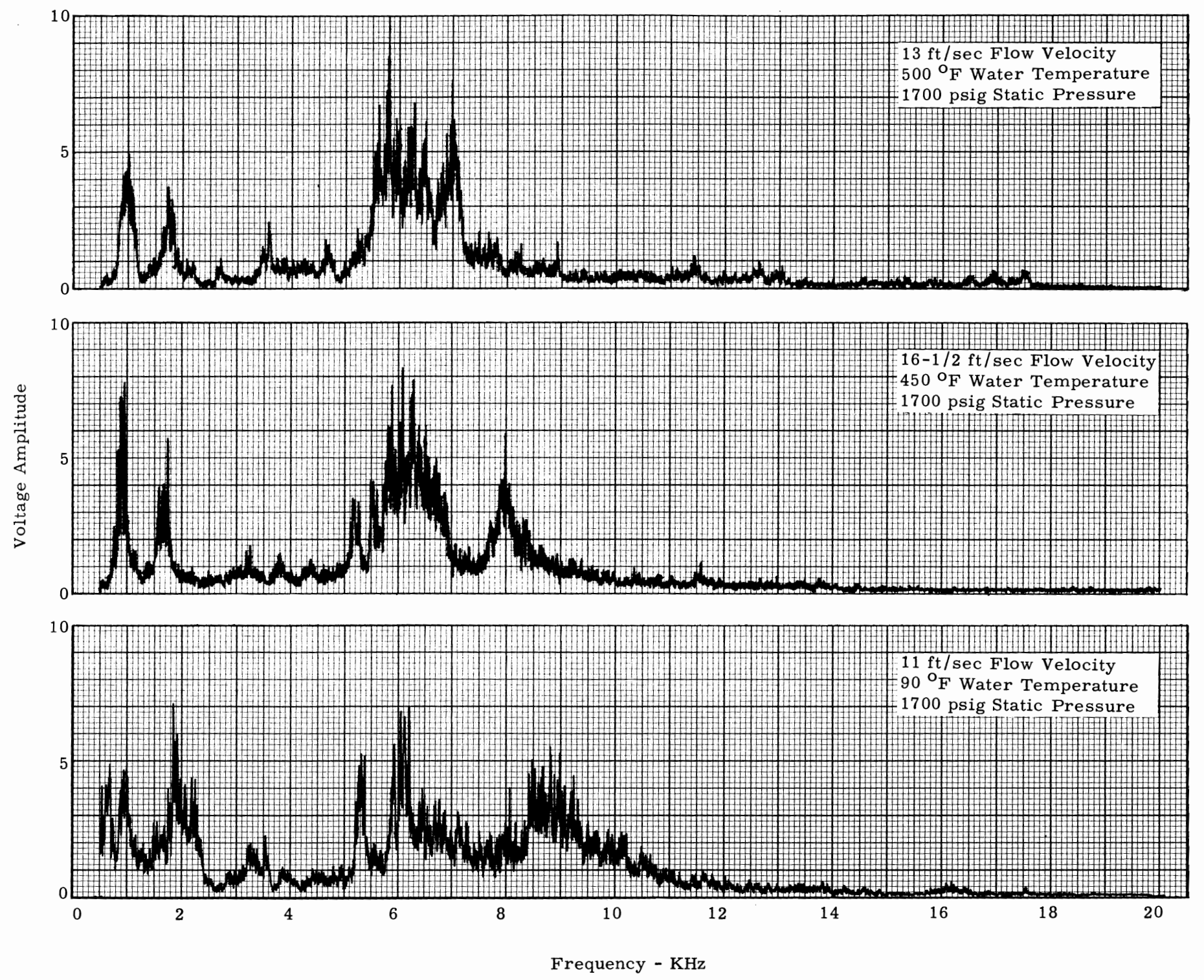

FIGURE 4.5. Spectrum Analysis of Hydraulic

Noise Data from an operating Reactor and

from a Hydraulic Test Loop 


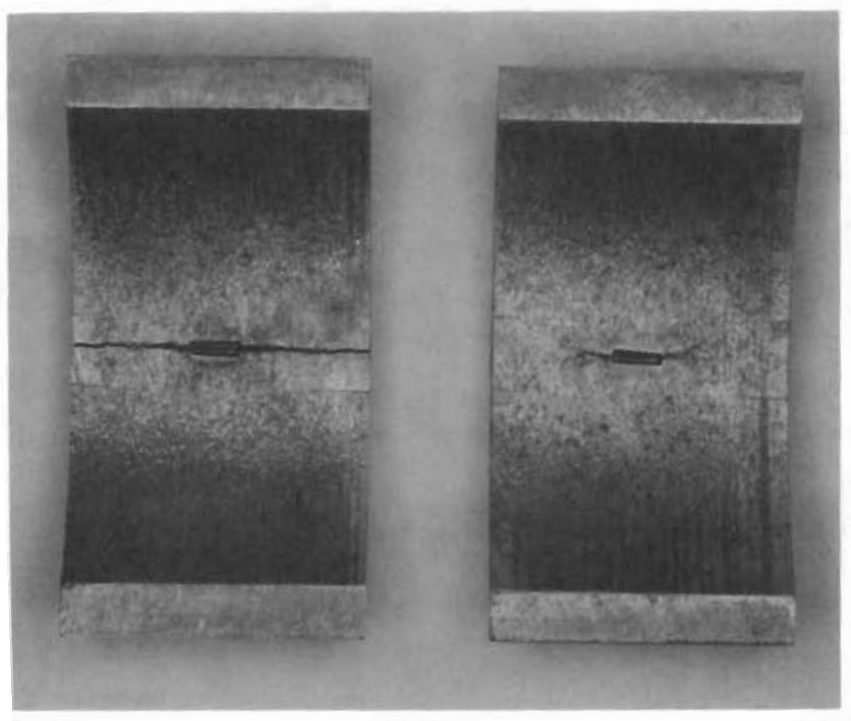

$-35$

Temperature $\left({ }^{\circ} \mathrm{F}\right)$

FIGURE 4.6. Drop weight Specimen

Behavior of $A 212 B$ llear DWTT of $-30^{\circ} \mathrm{F}$

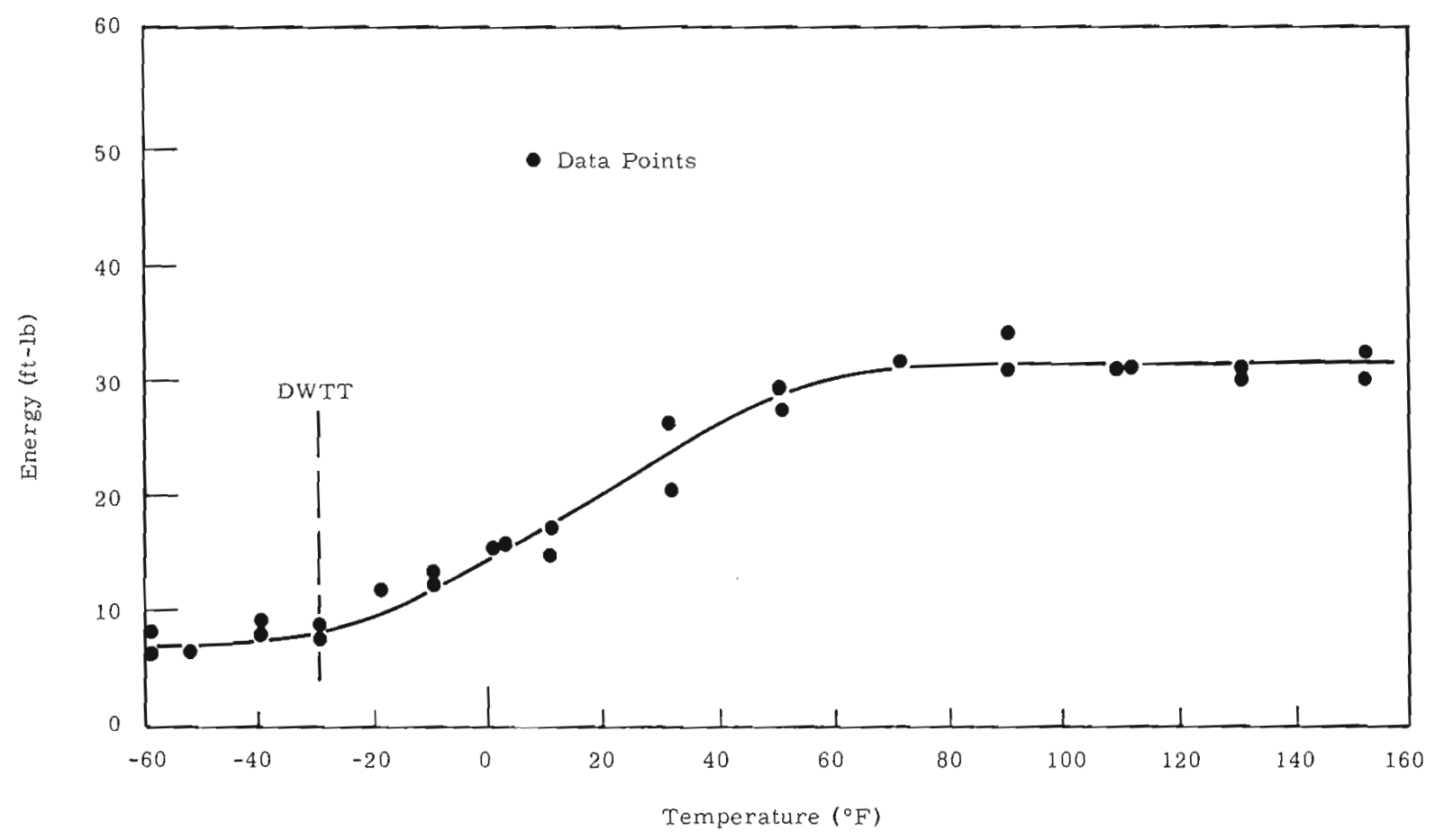

EIGURE 4.7. Charpy and Drop weight Test Results of $A 212 B$ Steel 
One of the major problems of this work is finding suitable reactor facilities for irradiating the large specimens. A potential irradiation facility is the Sandia Experimental Reactor Facility (SERF) in Albuquerque, New Mexico. During this period, gamma heat monitoring experiments were performed in the SERF. These experiments measured the temperature fluctuation of a $18,780 \mathrm{~g}$ block of 304 SS, at three different vertical positions in the reactor cel1, during a $7 \mathrm{hr}$ reactor operating cycle. A total of eight duplicate monitoring experiments were performed. Each experiment required continuous strip chart recording of the thermoelectric output of seven thermocouples. The strip chart data has been reduced to a useable graphic form. and now provides a basis for predicting the gamma heat to be expected with the irradiation of 1 arge specimens in the SERF. 


\title{
ENVIRONMENTAL STUDIES
}

\author{
R. F. Foster
}

\section{COLUMBIA RIVER SEDIMENTATION STUDIES}

\section{J. M. Nielsen}

Batte11e-Northwest and the U.S. Gélogical Survey cooperatively obtain and analyze samples of Columbia River water and sediment to study the behavior of radionuclides in the river environment. Samples of river water and suspended sediment have been taken at Pasco and Vancouver, Washington about every other day and composited for 2 weeks since 1963. During most of 1965 and 1966 , similar samples were also obtained at Umatilla, Oregon. So that one could follow the effects on the river environment during the shutdown of the reactors in July and August of 1966, the sampling was increased considerably, especially just after shutdown and startup.

Radionuclides being transported in the Columbia River during a period of shutdown of all of the Hanford reactors could come from three sources: 1) fal1out isotopes coming downstream from above the reactors, 2) cooling water - still being passed through the reactors, and 3) releases from the sediment and biota of the river bed.

Radionuclide data on a sample of river water obtained at Vernita (above the reactors) during reactor shutdown are shown in Table 5.I.

These numbers are orders of magnitude less than those found for the river below the reactors during normal operations but may be a significant part of river levels for some nuclides during reactor shutdown.
TABLE 5.I. Curies per Day of Five Radionuclides Found in the Columbia River Above the Hanford Reactors

\begin{tabular}{cc} 
Radionuclide & $\begin{array}{c}\text { Transport Rate, } \\
\text { Ci/day }\end{array}$ \\
\cline { 2 - 2 } $54 \mathrm{Mn}$ & 0.07 \\
${ }^{46} \mathrm{Sc}$ & 0.08 \\
$51 \mathrm{Cr}$ & 3 \\
$65 \mathrm{Zn}$ & 0.4 \\
$60 \mathrm{Co}$ & $<0.01$ \\
\hline
\end{tabular}

The coolant flow through the reactors is decreased during shutdown periods to between 5 and $15 \%$ of operating levels. The concentrations of relatively long lived radionuclides in this reduced flow do not decrease appreciably because most of them are formed over a period of time in the film on the tubes and fuel elements. Release to the effluent is by leaching and sloughing from this film; and this continues, to some extent, after shutdown even though there is little or no formation of additional activation products. Due to the sudden drop in coolant flow at shutdown, the total activity being released to the river dropped immediate $1 y$ to about $5 \%$ of operating levels for ${ }^{54} \mathrm{Mn},{ }^{60} \mathrm{Co}$, and ${ }^{65} \mathrm{Zn}$, to about $10 \%$ for ${ }^{46} \mathrm{Sc}$ and to about $1 \%$ for ${ }^{51} \mathrm{Cr}$. During the shutdown period, levels of ${ }^{54} \mathrm{Mn},{ }^{65} \mathrm{Zn}$, and ${ }^{51} \mathrm{Cr}$ being released continued to decline regularly while ${ }^{60} \mathrm{Co}$ and ${ }^{46} \mathrm{Sc}$ did not change perceptibly. At startup of the reactors: most of the nuclides returned to operating levels, or nearly so, within a few days. 
In Figures 5.1 through 5.5 are given the transport rates in curies per day of five major gamma emitting radionuclides found in the Columbia River at Pasco, Umati11a, and Vancouver. The transport rates given are for a combination of that found in solution and in suspended sediment. These values should be compared with similar data for a previous year (1) which are reproduced in Figure 5.6. These data show that during the high water period

1. R. W. Perkins, J. L. Nelson, and W. L. Haushizd. "Behavior and Transport of Radionuclides in the Columbia River Between Hanford and Vancouver, Washington," Limnology and oceanography, Vol. 11, pp. 235-248.

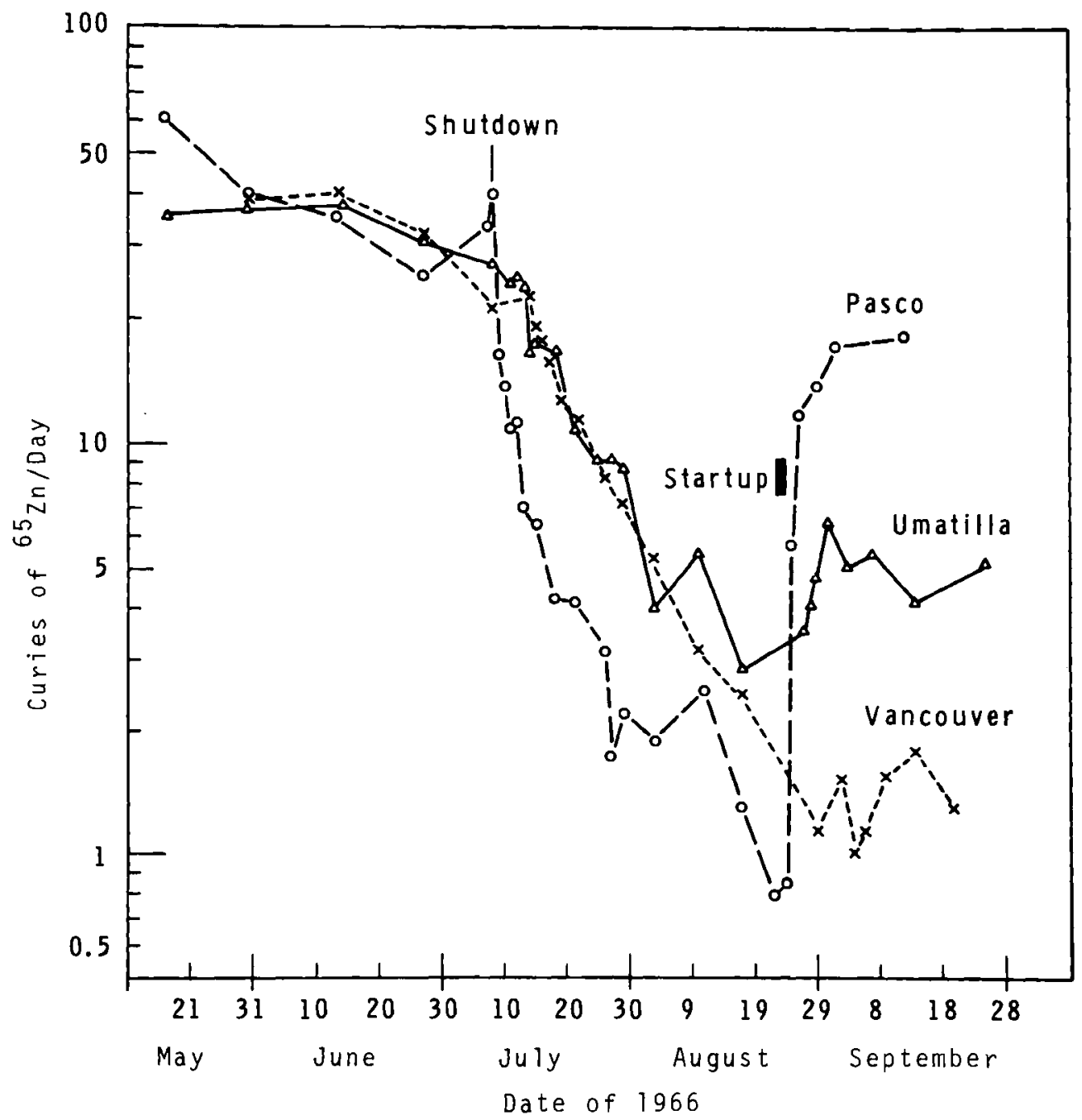

Neg $0671175-11$

FIGURE 5.1. Effect of Reactor Shutdown on Transport Rate of $55 \mathrm{Zn}$ at Three

Points in the Columbia River 


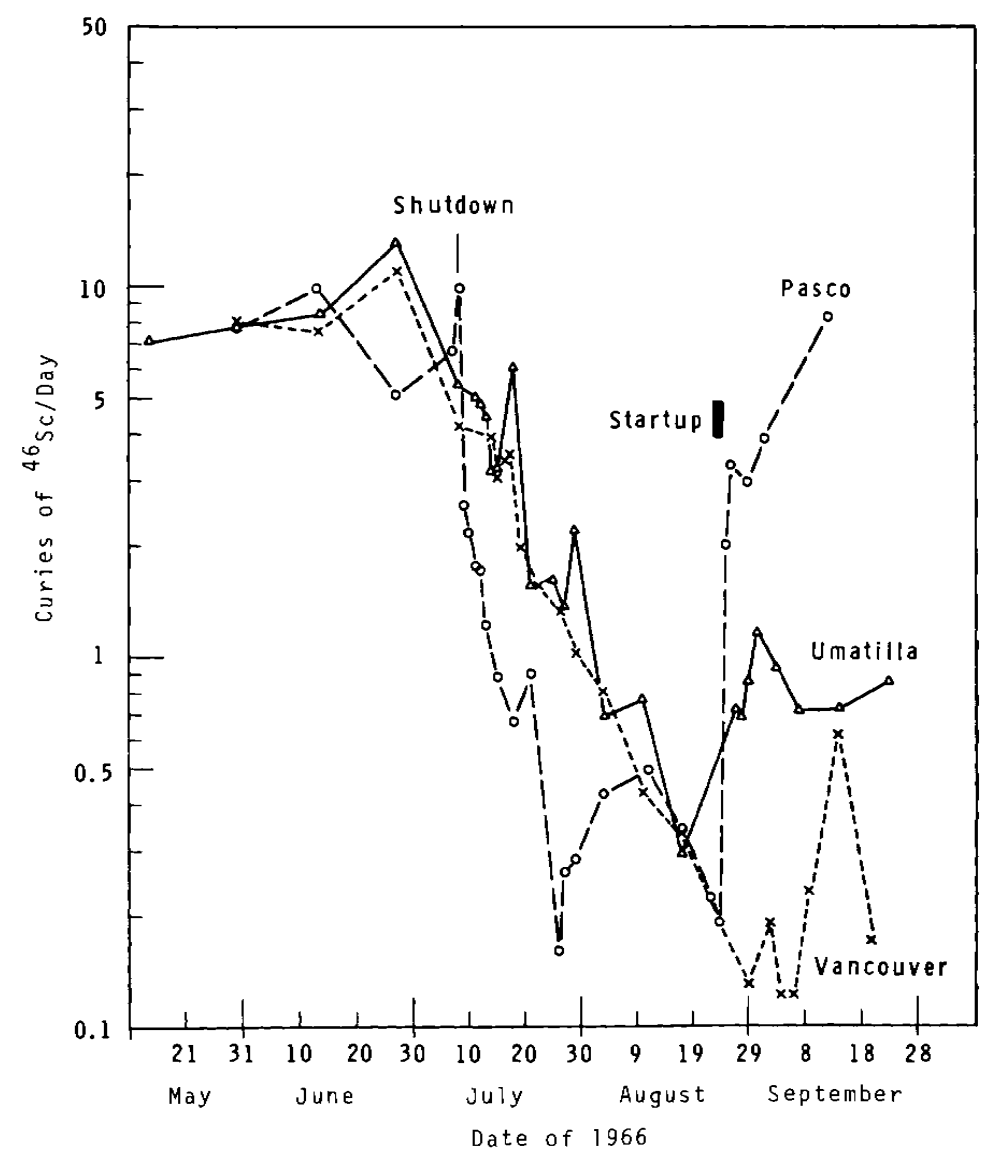

Neg $0671175-12$

FIGURE 5.2. Effect of Reactor Shutdown on Transport Rates of 46 SC at Three Points in the Columbia River

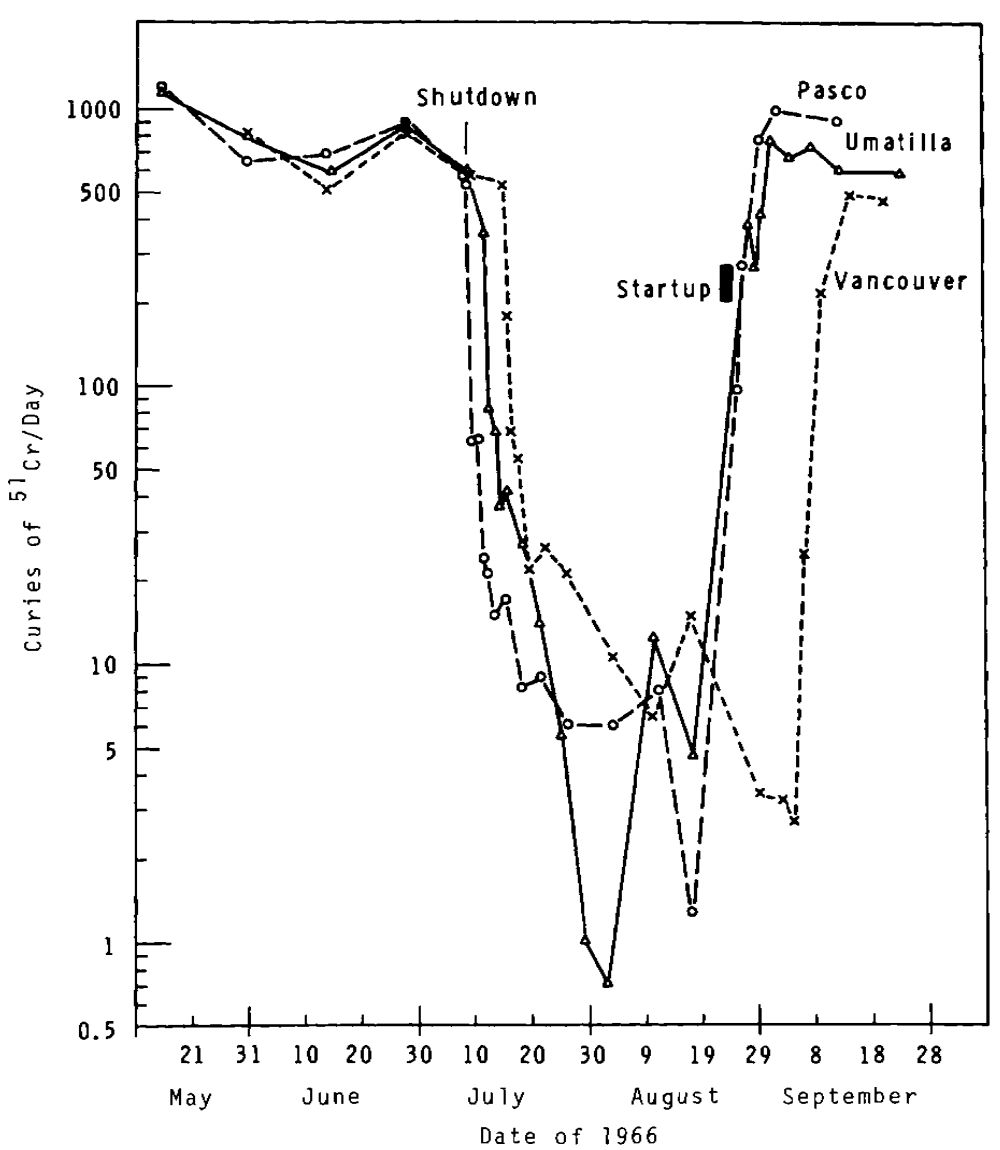

in

Neg $0671175-13$

FIGURE 5.3. Effect of Reactor Shutdown on Transport Rate of ${ }^{51} \mathrm{Cr}$ at Three Points in the Columbia River 


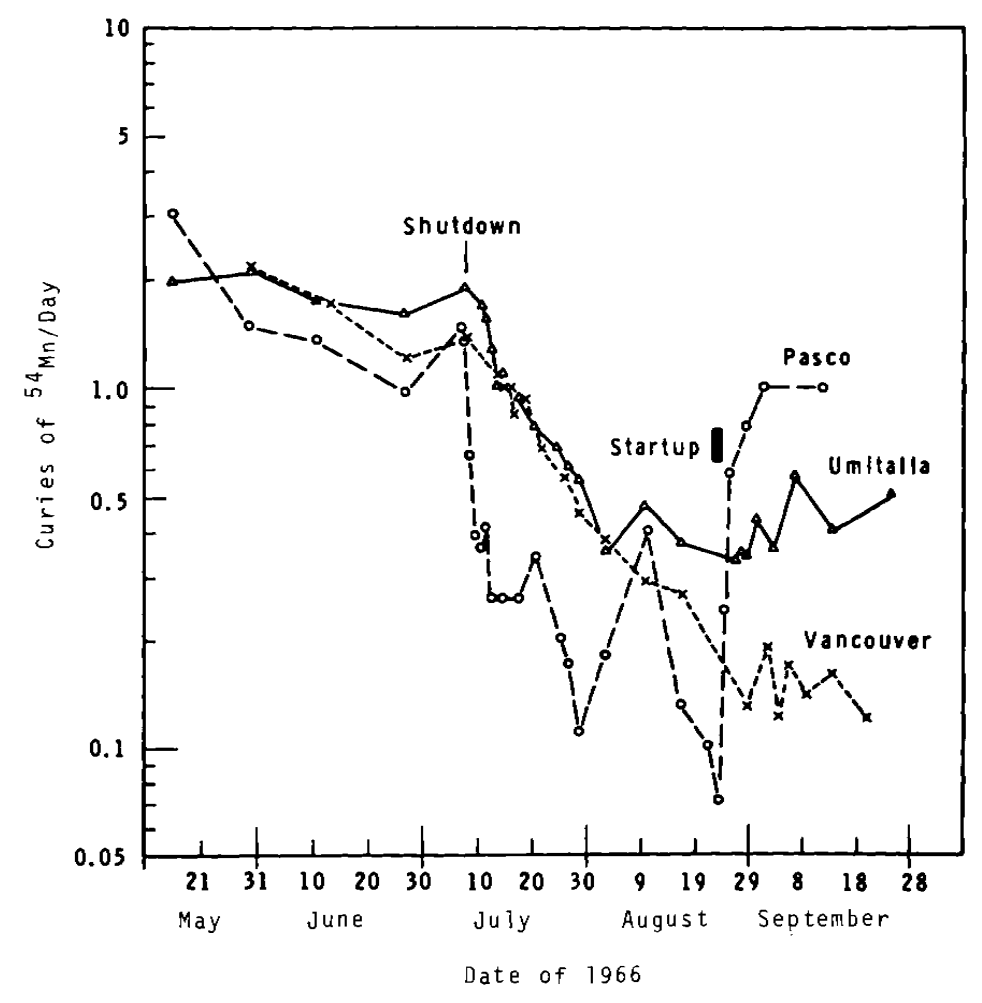

Neg $0671175-8$

FIGURE 5.4. Effect of Reactor Shutdown on Transport Rate of $54 M n$ at Three Points in the Columbia River

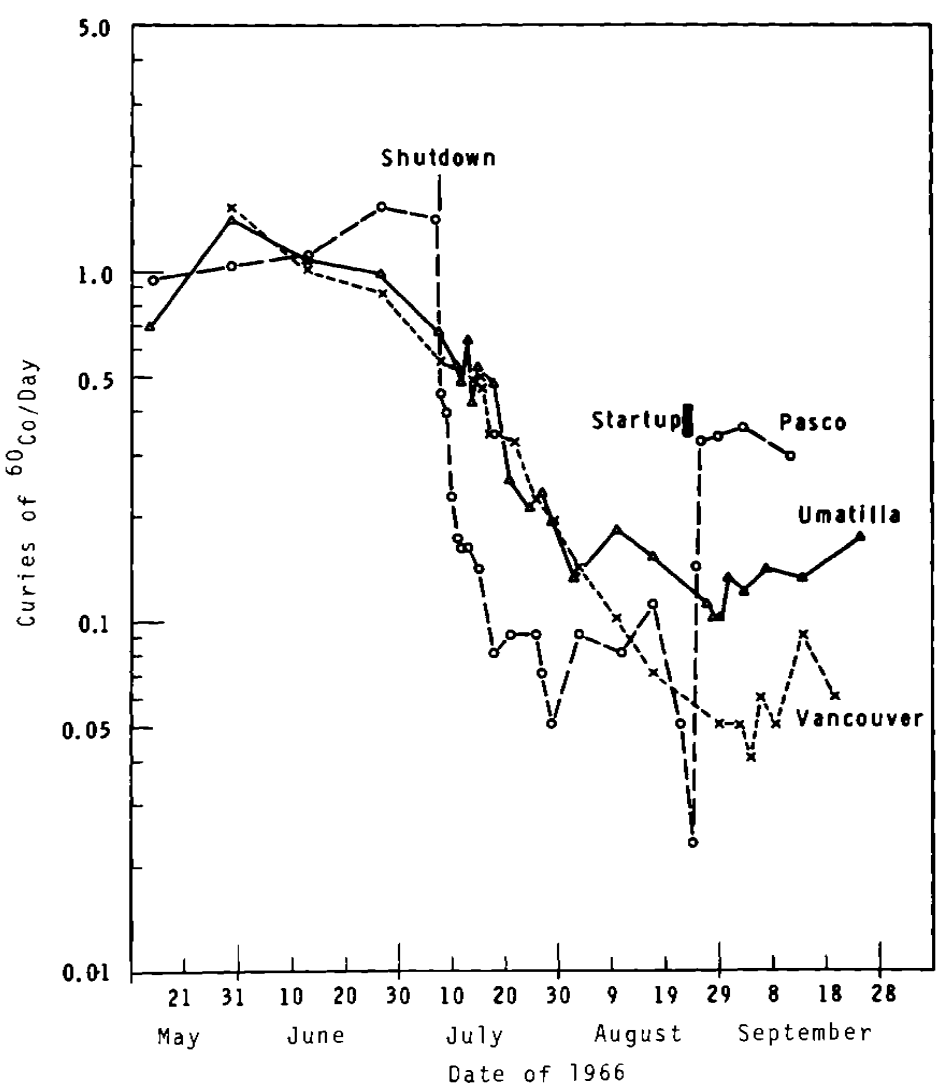

Neg $0671175-15$ FIGURE 5.5. Effect of Reactor Shutdown Points in the Columbia River 

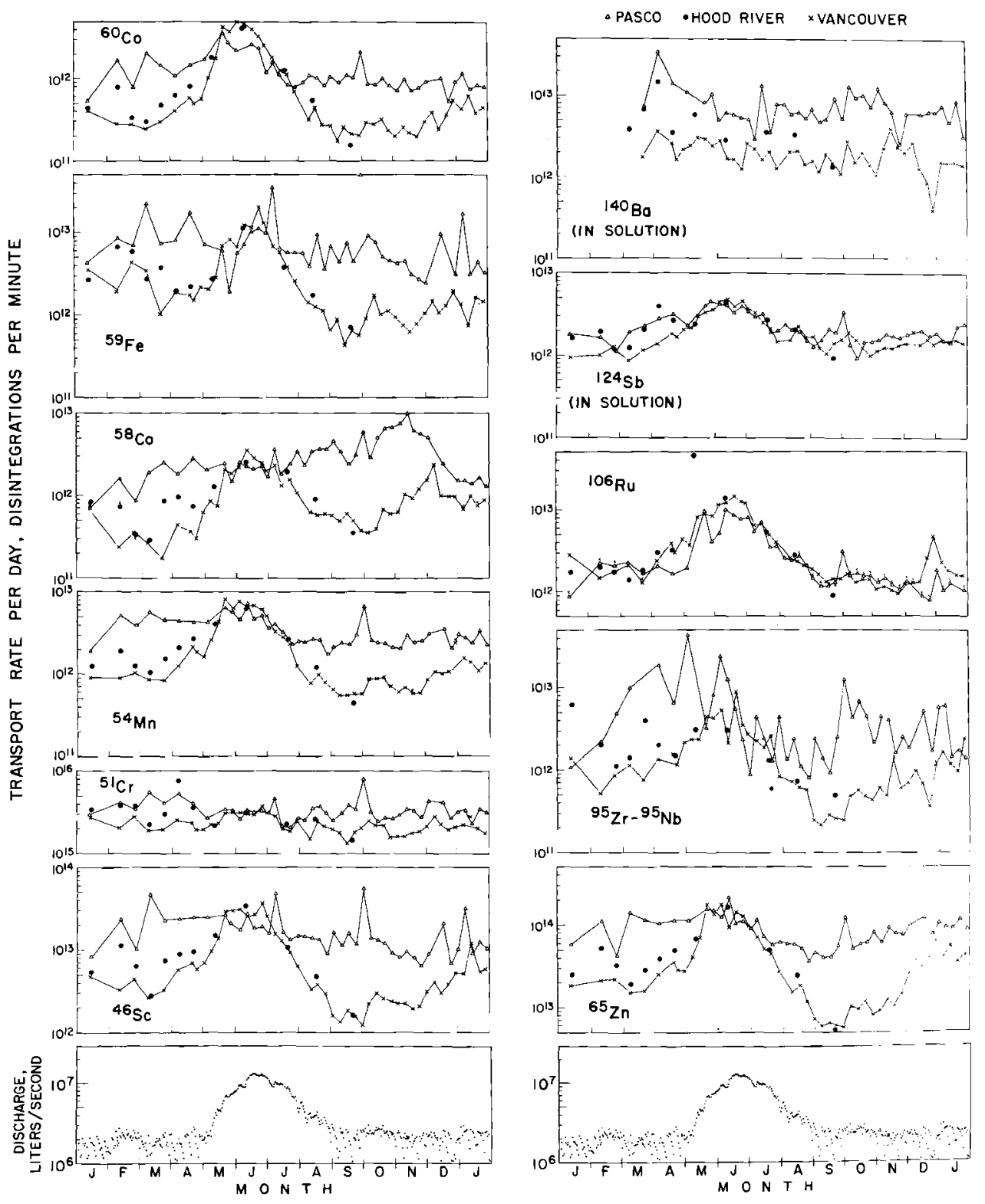

Neg $0653273-9$

FTGURE 5.6. Transport Rate of Radionuclides by the Columbia River at Pasco, Washington, Hood River, Oregon and

Vancouver, Washington for the Period

January 1964 Through January 1965 
of May, June, and early July, scouring of radionuclide-containing sediments causes the transport rates to be high and more or less the same for downstream points at Pasco. However, the normal picture is for transport at vancouver to decrease for several isotopes by about a factor of 10 during July and August. Thus, in Figures 5.1 through 5.5 the decreases shown at Umatilla and Vancouver for ${ }^{65} \mathrm{Zn},{ }^{54} \mathrm{Mn},{ }^{60} \mathrm{Co}$, and ${ }^{46} \mathrm{Sc}$ following shutdown are only slightly steeper and greater than those that would be expected in a year with no shutdowns.
Transport rates at Pasco, in contrast, dropped steeply in the few days following shutdown and recovered rapidly after startup. However, the drop in transport rate in the river at Pasco was not nearly as rapid as would be expected from reactor effluent data, indicating some release from the river bed. As an example, Figure 5.7 shows the period of bleeding or leaching of $65 \mathrm{zn}$ from the river bed. These data were calculated by subtracting the ${ }^{65} \mathrm{zn}$ in reactor effluent and that at Vernita from amounts measured in the river at vancouver. The scouring period shown

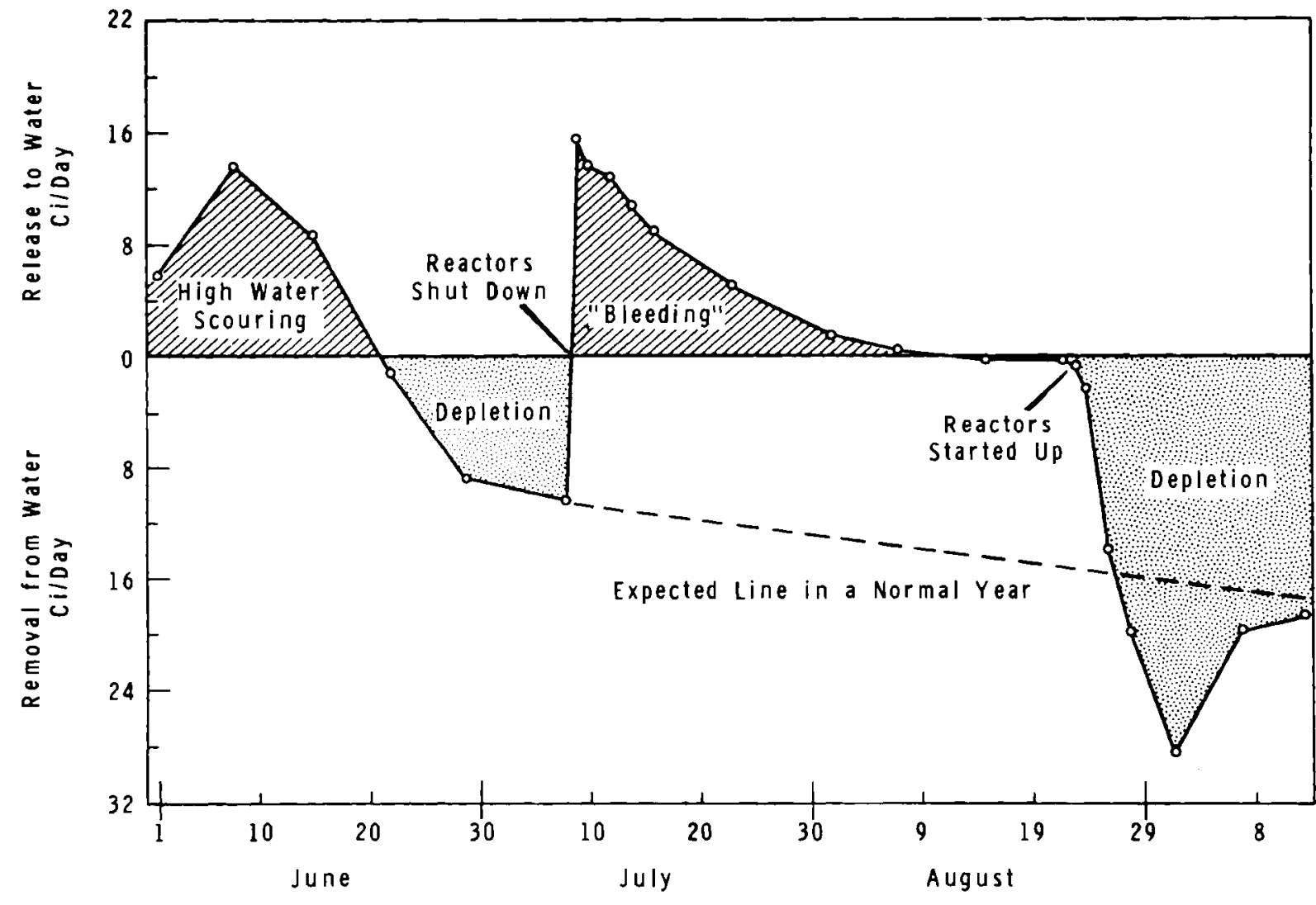

Date of 1966

Neg $0671175-6$

FIGURE 5.7. Periods of Uptake and Release of $65 \mathrm{Zn}$ by the Bed of the Columbia River Between the Hanford Reactors and Vancouver, Washington 
in May and June is normal for that time of year as is the change to a situation of accumulation in the river bed in early July (depletion from river water). At shutdown, however, when activity being added to the river dropped

- rapidly, the situation changed to one of "bleeding" or leaching of ${ }^{65} \mathrm{z}$ from the river bed. This gradually decreased to zero during shutdown and then at startup, accelerated depletion of ${ }^{65} \mathrm{zn}$ from solution was seen which then gradual1y returned to normal for that time of year. The dotted line shows approximately what would be expected for a year in which the reactors were not shut down.

${ }^{54} \mathrm{Mn},{ }^{46} \mathrm{Sc}$, and ${ }^{60} \mathrm{Co}$ react in a manner similar to ${ }^{65} \mathrm{zn}$ in the river, but ${ }^{51} \mathrm{Cr}$ is not depleted, scoured, or leached to near $1 y$ as large an extent due to its different chemical form. (1)
The data shown indicate that the Columbia River bed acts as a buffer to take up (and thus deplete from the water) radionuclides during most of the year and especially during low water and/or high rates of release of radionuclides to the river. Then in periods of high water and/or low additions to the river, the river bed gives up some of its load of isotopes to the water. This phenomenon could have far reaching effects in the event of a major accidental release to the river.

Core samples were taken during the period of the shutdown to see if any leaching could be measured in a direct manner. These cores were all taken at the same site near a buoy about 1000 yards upstream from McNary Dam. This site has been shown to be a major sediment deposition area probably

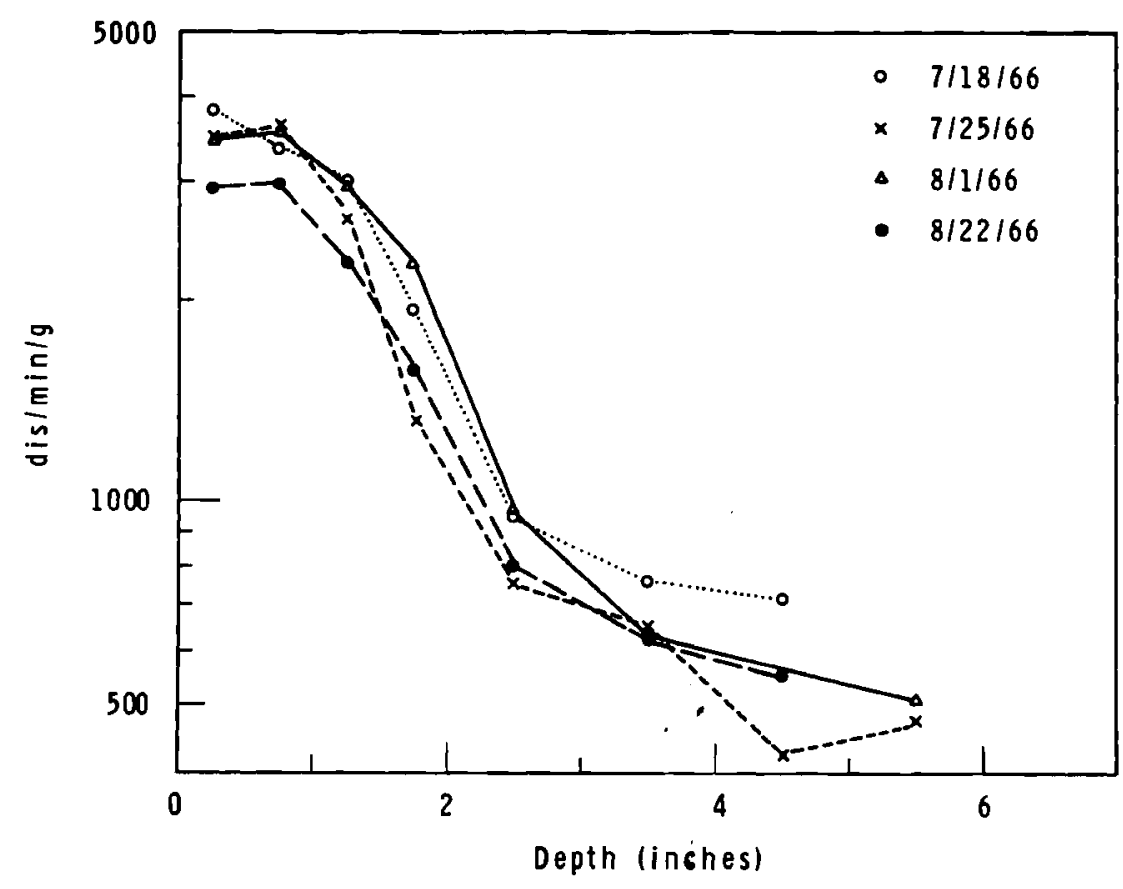

Neg $0671175-5$

EIGURE 5.8. $\quad 65$ Zn Activity in MeNary Cores 
during all parts of the year. (2) The cores were frozen, sliced into 0.5 to 1.0 in. depths, dried, and counted for

2. J.L. Nelson, R. W. Perkins, J. M. Nielsen, and W. L. Haushild. "Reactions of Radionuclides from the Hanford Reactors with Columbia River Sediments," Proceedings of the IAEA Symposium on "Disposal of Radioactive Wastes into Seas, Oceans, and Surface Waters," Vienna, Austria, 1966 . gamma emitters. The data are plotted versus depth on semilogarithmic paper in Figures 5.8 through 5.12 .

The radionuclide concentrations in the top three, $1 / 2$ in. sections of the core taken on August 22 show a definite decrease from those taken in July. The. flattening of all of the curves in the top of the cores has been noted previously during this time of the year and is

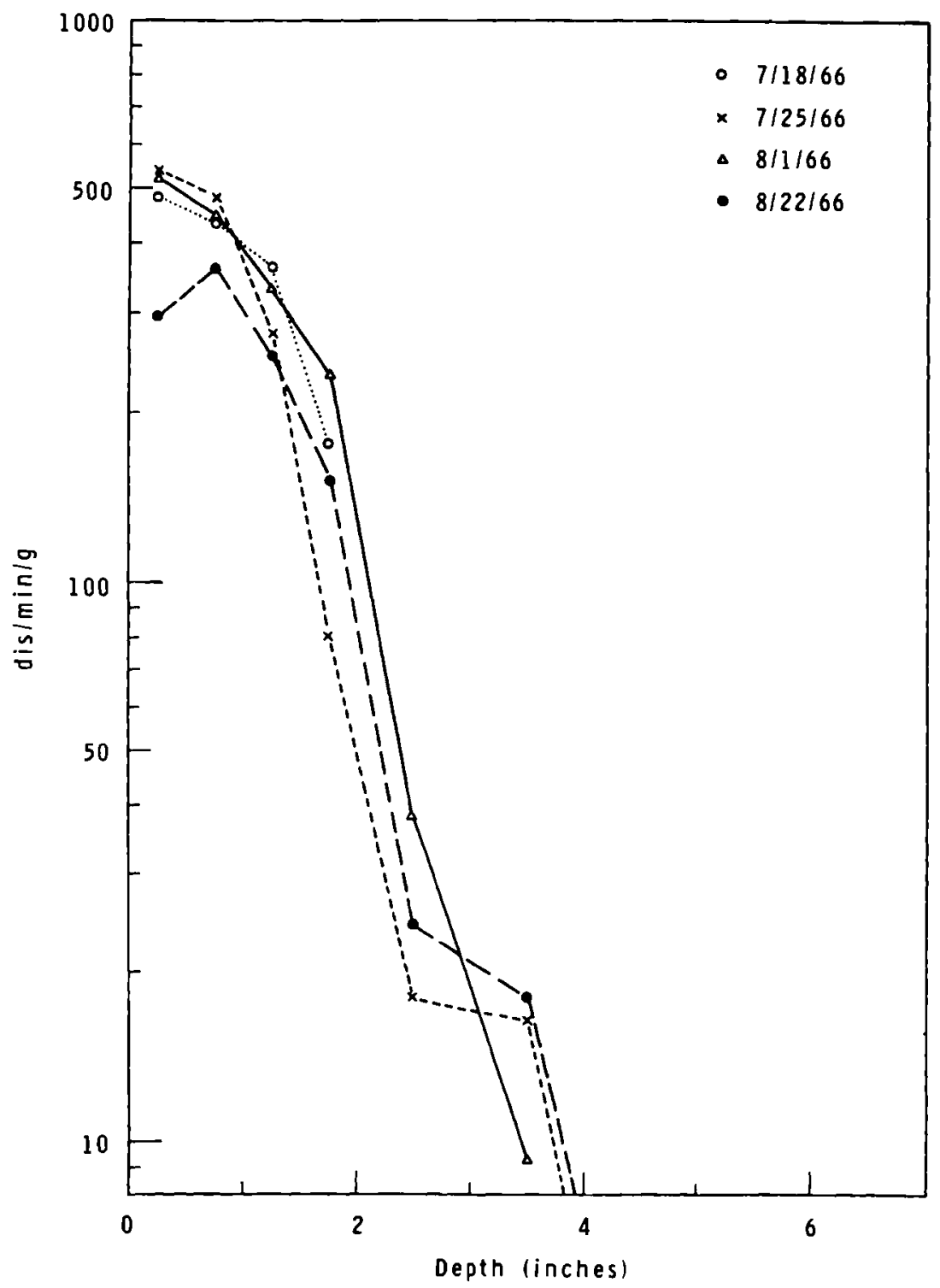

Neg $0671175-4$

$$
\text { FIGURE 5.9. }{ }^{46} \text { SC Activity in MCNary Cores }
$$




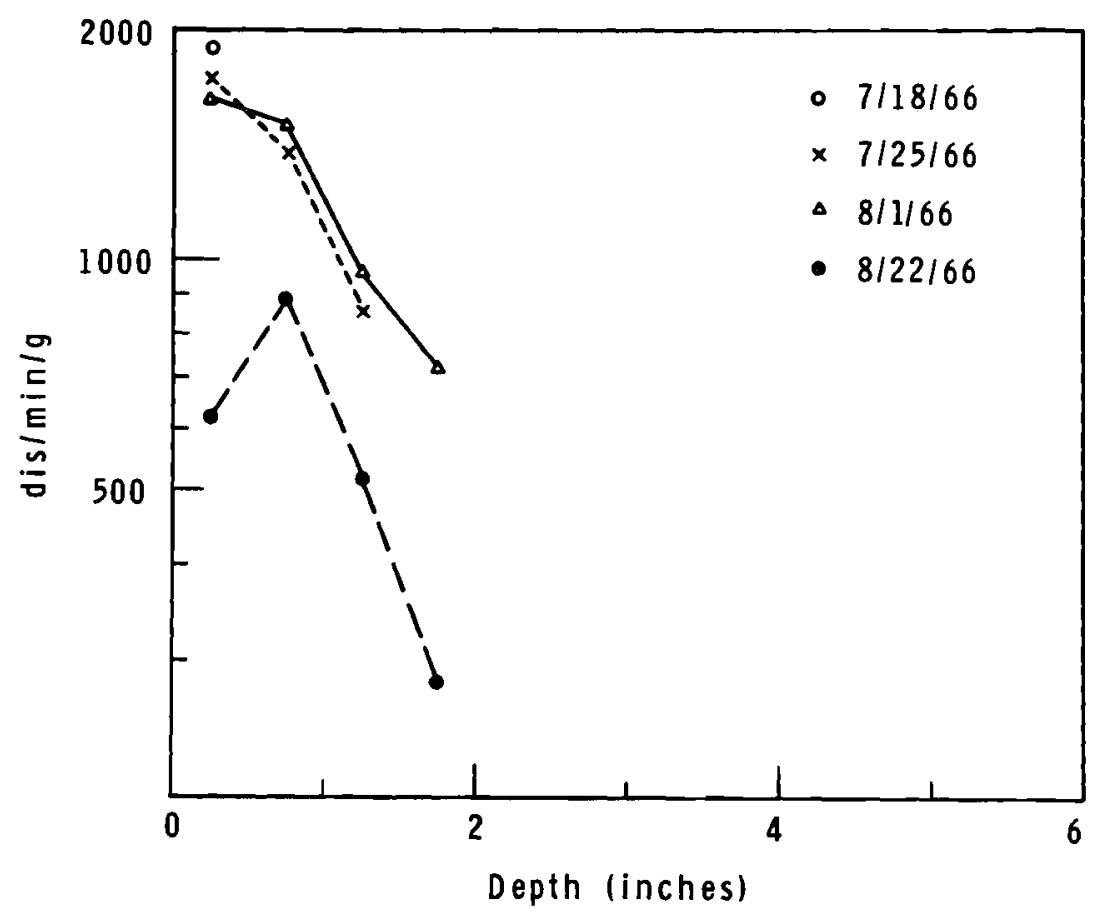

Neg $0671175-3$

FIGURE 5.10. ${ }^{51} \mathrm{Cr}$ Activity in MeNary Cores

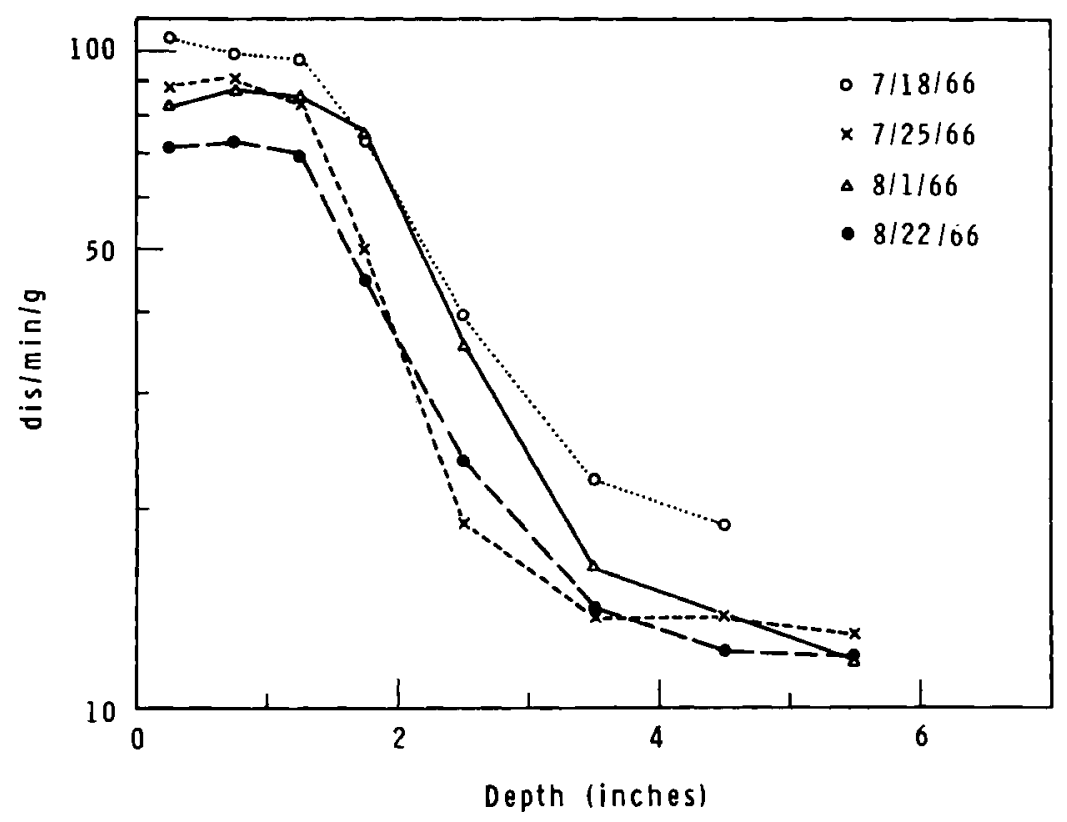

Neg $0671175-1$

EIGURE 5.11. ${ }^{54}$ Mn Activity in MoNary Cores 


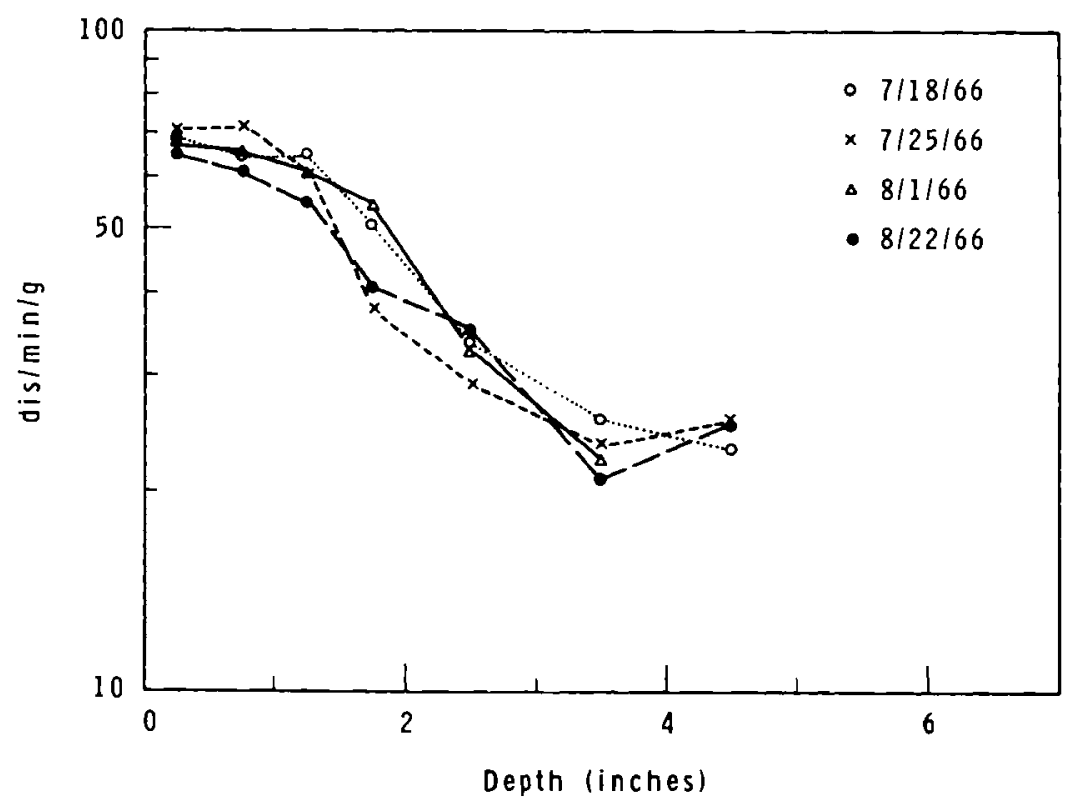

Neg $0671175-2$

FIGURE 5.12. ${ }^{60}$ Co Activity in MeNary Cores

believed to be due to rapid deposition of relatively low activity sediments during the spring period of high water and high suspended sediment. (2) Deeper parts of the cores are not significantly different from each other.

The decrease in radionuclide content in the sediment surface samples during the reactor shutdown could be due to any or a11 of three phenomena: 1) radioactive decay of previously deposited nuclides, 2) deposition on the sediment surface of relatively low level silt, or 3) leaching of radionuclides from the sediment by the river water, probably by a slow hydrolysis.

The degree of decrease of activity during the shutdown in the top layers is somewhat a function of half life as would be expected, but is too large for decay to be the sole contributor to the loss of activity. It can be calculated that approximately $80 \%$ of the decrease is accounted for by decay in the case of ${ }^{51} \mathrm{Cr}$ and ${ }^{46} \mathrm{Sc}$, but only about $50 \%$ of the decrease for ${ }^{65} \mathrm{Zn}$ and $25 \%$ of that for ${ }^{54} \mathrm{Mn}$ and ${ }^{60} \mathrm{Co}$ is accounted for by decay. Previous studies ( 3 ) have indicated that ${ }^{51} \mathrm{Cr}$ and ${ }^{46} \mathrm{Sc}$ are held more tightly to sediment than are the other three radionuclides, probably due to their trivalent form as compared to the divalent form of the other three nuclides. This evidence suggests that some radionuclides were leached from the river bed. sediments over a period of time in relation to the ionic attraction with which they are held by the sediment. It is hoped that this shutdown was of

3. J. L. Nelson, and N. H. Cutshall. "Studies of the Mechanisms of Retention Radionuclides in Columbia River Sediments," USAEC Research and Development, $B N W L-36$ III, $p p$. 3.75 .1965$. 
sufficient duration to provide a "dating layer" in the sediment for use in future years.

\section{DISPOSAL OF REACTOR OFF-GAS INTO SOIL} SYSTEMS

\section{- L. G. King}

During this quarter, the major emphasis has been on completing the methods

for analyzing the injection of gas into homogeneous media through a single we 11 . Results from this analysis can be used for determining the optimum placement of the injection structure to maximize the injection rate and the minimum time of travel of gas back to ground surface. The results will also be used to check node configurations for the finite difference solutions for the field situations encountered at the NRTS site and to provide initial estimates for the permeability to be used for these solutions.

Results to date include dimensionless graphs of the flow rate as a function of the geometry of the system; i.e., the total depth from water table to ground surface, the well diameter, the length of the injection structure, and depth of placement of injection structure below ground surface. For these graphs, the geometry factors have been scaled to the total depth so that the curves cover the range of variables of immediate interest. An example of these curves is shown on Figure 5.13,

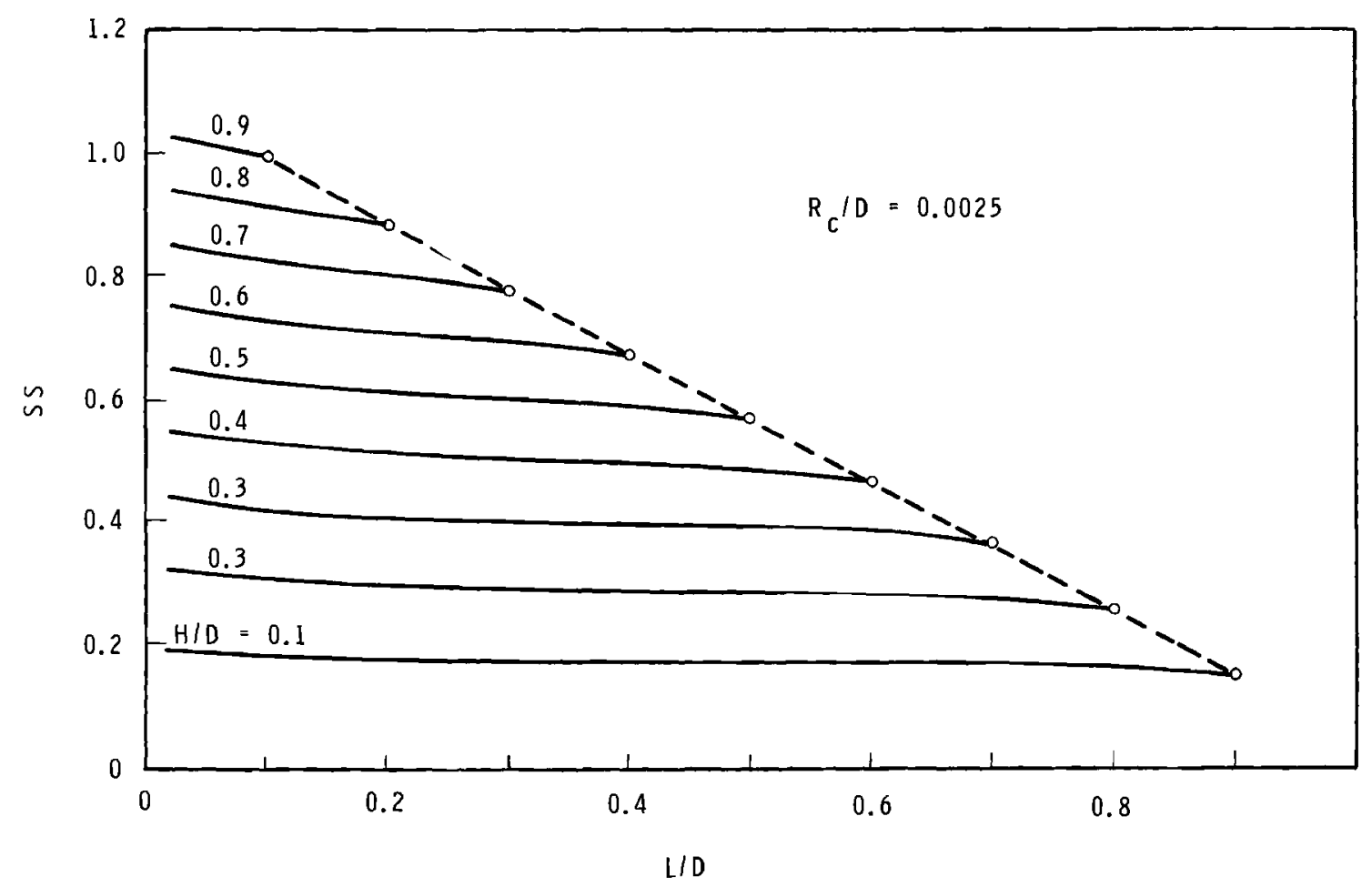

Neg $0670945-5$ 
where SS is the dimensionless flow rate to be used in the equation

$$
\begin{array}{r}
Q= \\
\left(1.1716 \times 10^{5}\right) \\
(\mathrm{k})(\mathrm{D})(\mathrm{SS})
\end{array}
$$

to give the flow rate $Q$ in standard cubic feet per minute. The geometry factors--L, D, $\mathrm{H}$, and $\mathrm{R}_{\mathrm{C}^{-}} \mathrm{in}^{-}$Equation (5.1) and Figure 5.13 are explained in the definition sketch of Figure 5.14. In Equation (5.1), $k$ is the permeability in square feet ( 1 darcy $=1.09 \times 10^{-11}$ square feet), FACTOR A is a function of temperature which involves both density and viscosity, and FACTOR B is a function of the injection pressure. Note that for a given $H / D$, the flow rate is rather insensitive to changes of $L / D$;

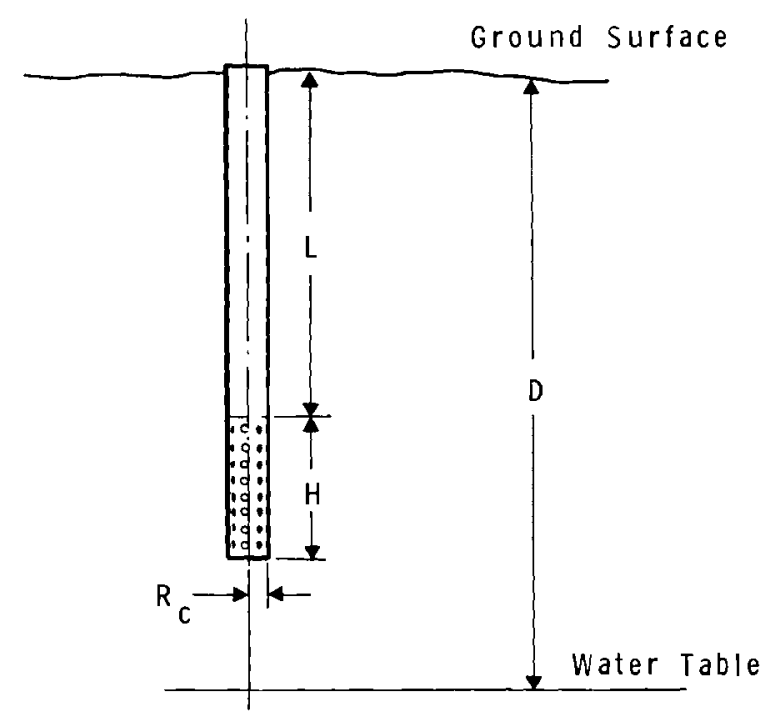

$D=$ Total Depth

$H=$ Perforated Injection Length

$R_{C}=$ Radius of Well

Neg $0670945-10$

FIGURE 5.14. Definition sketch for Underground Injection of Radioactive Gases i.e., the injection structure may be placed near the water table $(H / D+L / D=$ 1.0) without much sacrifice of flow rate, but such placement greatly increases time of gas travel back to the ground surface during pumping; and for a given duration of pumping, leaves the gas. bubble further below ground surface than a placement at small L/D values. These results, together with flow patterns and travel time distributions are being included in a report which is expected to be available by early summer.

As an example of the use of these results, assume $k=10$ darcys, porosity $=$ 0.2 , temperature $=20^{\circ} \mathrm{C}$, injection pressure $=5$ psig and $D=200 \mathrm{ft}$. Then for $\mathrm{R}_{\mathrm{c}} / \mathrm{D}=2.5 \times 10^{-3}, \mathrm{H} / \mathrm{D}=0.3, \mathrm{~L} / \mathrm{D}=0.6$, the flow rate is 1050 standard $\mathrm{ft}^{3} / \mathrm{min}$ and from curves similar to Figure 5.13 for minimum travel times, the minimum time for gas trave 1 back to ground surface is $22.3 \mathrm{hr}$. If $H / D=0.3$ and L/D -0.7 the flow rate drops to 960 standard $\mathrm{ft}^{3} / \mathrm{min}$ and the minimum trave 1 time is $31 \mathrm{hr}$.

These results are expected to aid in the testing of finite difference solutions to be used for the NRTS field conditions. Work is expected to focus on these solutions in the coming quarter.

SIMULATION MODELING OF THERMAL GENERATION IN SELECTED RIVER SYSTEMS

\section{R. T. Jaske}

The primary object of this study is the further development and application of a system of mathematical modeling to 1) the determination of the downstream thermal effects of industrial plants with high heat rejections; 2) the verification and application of methods of 
apportionment of available thermal increments on a rational basis; and 3) the development of an acceptable technology for decision making in the event that nonstandard conditions arise either as a consequence of equipment or human

- failure, or the occurrence of major drouths or diversions.

Accomplishment of this study is based

- on the use of a digital simulation system originated as a means of assessing the thermal impact of the Hanford plant on regional water quality. Two specific areas with relatively clean boundaries have been selected to obtain verification of the application of the model to systems far removed from the Columbia River. The areas selected are :

- The Illinois River below the Dresden plant

- The Deerfield River below the Yankee plant

Specific tasks in each case include:

1) Accumulation and processing of his torical data, including weather.

2) Development of a mathematical description of the stream.

3) Simulation operations with inistorical, current, and expected hydrology and plant performance factors.

4) Verification on the prototype using in situ recording.

5) Determination of appropriate error functions.

Progress to date has been concerned primarily with the Illinois River although basic data for the Deerfield River are being collected. For the Illinois case the following have been completed:

- Sufficient river sounding and hydrology data have been collected to perform operations as far downstream as Starved Rock Dam, 41 miles below the Dresden plant. Additional downstream data have been received.

- Arrangements have been made with the National weather Data Center for direct access to stored information and for punching of the data to the format of the simulation program.

- Tentative arrangements have been made with the USGS to install thermographs at selected locations for verification purposes.

- Computer runs have been made for historical and base cases, and for prediction cases for conditions after Dresden \#2 and \#3 have been completed, for the first $28 \mathrm{miles}$ downstream of the site.

Based on the work completed so far it can be stated that:

- The applicability of the digital simulation system to the Illinois River system appears satisfactory. A11 base case data using historica 1 inputs fall within the envelope of maximum and minimum temperature data.

- The existing Dresden \#1 has only nominal temperature effects 28 miles downstream.

- Dresden plants \#2 and \#3, either singly or in combined operations with the existing plant, will have significant effects on temperature of the Illinois River below a point 41 miles downstream of the power plant site.

At this preliminary stage of the study, it appears that the simulation system as such is quite flexible and 
capable of translation to almost any fresh water body for which sufficient data are available. However, since the system was designed around tine use of daily average data, there is a data interface problem since most of the historical records were taken before modern data processing techniques were available and have been carefully averaged to reduce numerical bulk. After 1964, however, directly applicable digital data can be produced for most essential locations.

Additional research is also needed to confirm the present tentative conclusion that one or more regional weather stations can successfully provide enough trend data for a regional water quality simulation system. An additional problem arises in the determination of the current status of a regional system. Advanced monitoring techniques such as infrared and "K" band radar may provide a method of es tablishing a regional status report; one or more of these methods is planned for use in the latter phases of this study.

\section{GEOPHYSICAL EXPLORATION OF RATTLESNAKE}

NO. 1 WELL

J. R. Raymond

The Rattlesnake Hills No. 1 deep stratigraphic test well was drilled for the Standard Oil Company of California during 1957 and 1958. Several other companies also contributed financial support during the course of the work. We11 location is: $330 \mathrm{ft} \mathrm{N}$ and $330 \mathrm{ft} W$ of the SE corner of section 15, township $11 \mathrm{~N}$, Range $24 \mathrm{E}$. Well depth is $10,655 \mathrm{ft}$. The objective of the drilling was to penetrate the thick Columbia River basalt - basalt interbed series near the basin center and near the axis of a major anticlinal ridge (Rattlesnake Hi11s). Knowledge of rock types and structures underlying the basalt would determine feasibility of further petroleum exploration, but basalt was not penetrated at completed we 11 depth. As the basalt series were of secondary in-. terest, only cursory studies and examinations were made: ditch-sample visual examination, standard "E" $10 \mathrm{~g}$, gamma and neutron $10 \mathrm{~g}$, some vertical and sidehole coring and some petrographic work.

The Rattlesnake Hills well provides unique access to one of the world's thickest basalt sections and presents an opportunity for applied and basic research on the section by use of downhole geophysical methods. Funds were recently allocated to the Pacific Northwest Laboratory for in-we11 studies of this test hole. Two separate operations (and contractors) were involved in the proposed work on the Rattlesnake Hills well: 1) well entry, cleanout and fluid conditioning and 2) logging of the hole with a number of geophysical tools to obtain the desired information.

The objective of the geophysical program is to obtain definitive information on the characteristics of the thick basalt - basalt interbed series. The logging program was selected to provide quantitative information on the following parameters: Basalt flow and interbed thicknesses; formation resis-" tivities; spontaneous potential; formation density, porosity and permeability; mud invasion and cake thickness; holesize variations; nature of the pore fluid (saline or fresh water); sidehole core samples, temperature at depth (and heat flow information) and seismic characteristics. 
A11 preliminary work for this study was completed during this quarter.

Specifications were completed for well re-entry and cleanout and the logging program was selected and specified. Bid packages were assembled and sent to - prospective drilling contractors and contractor selection was made on the basis of the returned bids. Entry and work permission was given by the 1 andowner. Proposed work was discussed with the Division Geologist, Western Operations, Standard Oil Co. of California; the State Geology Department; and the Tacoma office of the U.S.G.S. The Standard Oil Co. file on the we 11 was examined and copies of logs and other information that were not released to the public were obtained. Drilling samples were also received. A portion of the vertical core taken in the well at $8100 \mathrm{ft}$ was obtained from the Washington State Geology Department and thin sections were prepared from this sample. The core was described as "basalt" in the Standard Oil Co. logs and thin section examination confirms that the core is weathered and altered basalt. X-ray diffraction studies were made of the core sample.

If the contracts can be let, on-site work should be underway by the latter part of April 1967, and all logging and evaluation should be completed by the end of May 1967. 


\section{DISTRIBUTION}

No. of

Copies

Argonne National Laboratory
L. Baker
C. E. Dickerman
S. Fistedis
P. Lottes
R. C. Voge 1

52

Atomic Energy Commission, Washington

Advisory Committee on Reactor Safeguards

R. F. Fraley

Division of Reactor Development and Technology

R. S. Brodsky

K. Cooper

J. W. Crawford

H. L. Hamester

J. A. Li eberman (5)

R. R. Newton (5)

A. J. Pressesky

I. C. Roberts

E. E. Sinclair

S. A. Szawlewicz

M. J. Whitman

Division of Compliance

L. Kornblith, Jr.

Division of Operational

Safety

H. Gilbert

Division of Production

G. B. Pleat

Division of Safety Standards

M. Bolotsky

J. DiNunno (10)

A. B. Holt

1 Atomic Energy Commission Division of Compliance, Region IV

J. W. Flora

4 Atomic Energy Commission,

Richland

office of RDT site

Representative

P. G. Holsted (3)

A. S. Waterhouse
No. of

Copies

1 Atomic Energy Commission

USAEC Technical Representative

G. D. Boyer

1 Auburn University

School of Engineering and

Engineering Experiment Station

G. H. Nix

6 Battelle Memorial Institute, Columbus

A. R. Duffy

D. L. Morrison/

R. L. Ritzman (1)

S. Paprocki (2)

D. N. Saunderman (2)

1 Bechte1 Corporation

R. Griffin

1 Brookhaven National Laboratory

A. W. Castleman

1 Cha1k River Nuclear Laboratories Chalk River, Ontario, Canada Station 3

G. Hake

1 Chicago Operations Office

Atomic Energy Commission

D. M. Gardiner

1 Consolidated Edison Company

J. J. Grob

5 Division of Technical

Information Extension

2 Douglas United Nuclear

T. W. Ambrose

J. R. Spink

2 General Electric Company, Richland

N. R. Miller

J. W. Riches

3 General Electric Company, San Jose

M. L. Siegler

S. Vandenberg

G. E. Wade 
No. of

Copies

1 Harvard Air Cleaning

Laboratory

2 Idaho Nuclear Corporation

J. A. Buckham

C. M. Slansky

N. K. Sowards

2 Idaho Operations Office Atomic Energy Commission

D. Wi $11 \mathrm{i}$ ams

2 IIT Research Institute

E. Gallagher

T. A. Zaker

2 Isochem, Inc.

o. F. Hil1

G. R. Kiel

1 Los Alamos Scientific Laboratory

J. H. Russe1, K. Division

1 MPR Associates, Inc.

T. Rockwe 11 I I I

1 National Bureau of Standards

C. Muehlhause

1 Naval Ordiance Laboratory

J. Proctor

1 North Carolina State University

M. N. Ozisik

$1 \quad$ Nuclear Fuels Services

R. P. Wis chow

9 Oak Ridge National Laboratory

R. E. Adams

R. Blanco

J. Buchanan

W. B. Cottre 11

D. Ferguson

C. E. Miller

G. W. Parker

L. F. Parsley

4 Oak Ridge.Operations Office Atomic Energy Commission

D. Cope (2)

E. Delaney

W. L. Smalley
No. of

Copies

1

$\frac{\text { Oregon State University }}{\text { James Knudson }}$

1 Pacific Gas and Electric Company

W. Nutting

10

Philips Petroleum Company

G. O. Bright

G. F. Brockett

G. B. Matheny

W. E. Nyer (2)

F. Schroeder (2)

N. K. Sowards

T. R. Wilson (2)

3 Richland Operations office

C. L. Robinson

R. K. Sharp

Technical Information

Library

1 San Francisco Operations Office Atomic Energy Commission

Lt. Col. J. B. Radcliffe

1 Savannah River Laboratories

A. H. Peters

2

TRW Incorporation

TRW Systems Group

D. B. Langmuir

S. M. Zivi

2 University of California

Institute of Engineering Research

H. A. Johnson

V. E. Schrock

1

University of Washington

We11s Moulton

1 Westinghouse Electric Co. (APO)

Robert Wiesman

37

Batte $11 \mathrm{e}$-Northwest

F. W. A1baugh

J. M. Batch

J. J. Cadwe 11

D. L. Condotta

F. G. Dawson 
Battelle-Northwest (contd)
D. R. deHalas
R. F. Foster
J. C. Fox
J. J. Fuquay
W. A. Haney
H. Harty
R. T. Jaske
R. L. Junkins
A. R. Keene
J. M. Nielson
R. E. Nightingale
H. M. Parker
R. S. Paul
L. T. Pedersen

D. L. Reid

W. D. Richmond

G. J. Rogers

L. C. Schwendiman

D. E. Simpson

J. C. Spanner

E. E. Voiland

R. G. Wheeler

N. G. Wittenbrock

D. C. Worlton

Patent Section (2)

Technical Information Files (5)

Technical Publications 
. 